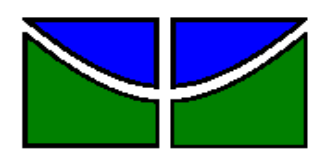

UNIVERSIDADE DE BRASÍLIA

FACULDADE DE EDUCAÇÃO

PROGRAMA DE PÓS-GRADUAÇÃO EM EDUCAÇÃO

\title{
A SALA DE AULA COMO ESPAÇO RELACIONAL: O OLHAR DO PROFESSOR PARA AS SINGULARIDADES DOS ALUNOS
}

\author{
LUANA VAZ
}

BRASÍLIA - DF 
LUANA VAZ

\section{A SALA DE AULA COMO ESPAÇO RELACIONAL: O OLHAR DO PROFESSOR PARA AS SINGULARIDADES DOS ALUNOS}

Dissertação apresentada ao Programa de Pósgraduação da Faculdade de Educação, da Universidade de Brasília, como parte dos requisitos para obtenção do título de Mestre em Educação, na Linha de Pesquisa Escola, Aprendizagem, Ação Pedagógica e Subjetividade na Educação.

Orientadora: Prof. ${ }^{a}$ Dr. $^{\text {a }}$ Cristina Massot Madeira Coelho 


\section{LUANA VAZ}

Dissertação apresentada ao Programa de Pósgraduação da Faculdade de Educação, da Universidade de Brasília, como parte dos requisitos para obtenção do título de Mestre em Educação, na Linha de Pesquisa Escola, Aprendizagem, Ação Pedagógica e Subjetividade na Educação.

\section{BANCA EXAMINADORA}

\section{Prof. Dra. Cristina Massot Madeira Coelho \\ Faculdade de Educação - FE/UnB \\ Orientadora}

Prof. Dra. Luciana Campolina de Oliveira

Faculdade de Ciências da Educação e da Saúde - UniCeub

Examinadora

Prof. Dr. Fernando Luis González Rey

Faculdade de Educação - FE/UnB

Examinador

Prof. Dra. Maria CarmenVillela Rosa Tacca

Faculdade de Educação - FE/UnB

Suplente 


\section{AGRADECIMENTOS}

A Deus, pelo dom da vida e por ser minha base e refúgio em todos os momentos.

Aos meus pais, Lucelena e Edenval, por todo amor e cuidado, por me ensinarem o valor da educação e da persistência, e por sempre acreditarem em mim.

À minha filha, Letícia, pela alegria e companheirismo em todos os momentos. Por me ensinar a me rever e me reinventar no dia a dia.

Ao meu marido, Rodrigo, que sempre me incentivou e com muito amor me sustentou nos momentos de dificuldade no percurso acadêmico.

Aos meus irmãos e familiares, por todo o apoio e pelas alegrias de fazer parte de uma família grande.

À minha querida orientadora Cristina, pela sutileza na caminhada. Colaborou com minha formação desde a graduação e foi uma grande incentivadora durante o Mestrado me incentivando a me arriscar mais na vida acadêmica. Para além de todo o conhecimento e colaboração na pesquisa, agradeço por sempre acreditar na minha capacidade.

Aos colegas de pós-graduação, especialmente Karina, Luciana, Débora, Marluce, Patrícia, Aictyr, Valdicéia, Carol Nunes, Carol Velho, Kátia, Érica, Robson e Andressa pelas trocas, parceria e acolhimento. À Karina minha gratidão pela paciência, disponibilidade e bom humor no compartilhamento dos desafios da pesquisa.

Aos professores da banca, pela disponibilidade em colaborar com meu trabalho e trazer considerações que irão enriquecer ainda mais minha formação enquanto pesquisadora.

Aos participantes da pesquisa, professores, diretora e alunos, por me permitirem vivenciar momentos de grande riqueza como pesquisadora iniciante e por me ajudarem a repensar meu papel como professora.

Aos colegas de profissão, pelo incentivo, apoio e orgulho demonstrado pelas minhas conquistas e por me ensinarem, cada um de uma maneira singular, a me tornar professora. Em especial agradeço ao colega Jefferson, que me encorajou a ingressar na pós-graduação.

À Secretaria de Educação, pela possibilidade de ter tido afastamento para estudos e pela disponibilidade na realização de pesquisa em escolas públicas.

A todas as crianças que já foram meus alunos, por me ensinarem que o desenvolvimento humano é rico, instigante e cheio de possibilidades. 
Certa vez, uma professora revelou o seguinte segredo... Da minha época de escola? Ah...

A grande lembrança da minha época de escola são os olhos da minha professora quando lia uma história para a turma.

Os seus olhos transitavam das páginas do livro para a turma, da turma para as páginas do livro, num passeio suave, quase um bailado. Do livro para a turma, da turma para o livro, sem que a leitura sofresse qualquer tropeço. Suave bailado: das páginas do livro para a turma, da turma para as páginas do livro.

E eu torcia para que os seus olhos de leitora esbarrassem nos meus olhos de ouvinte - e eles sempre se esbarravam, $e$ até demoravam uns nos outros.

Cheguei a imaginar, na minha imaginação de menina, que a história também estava escrita nos nossos olhos. Era como se a história estivesse sendo lida, alternadamente, no livro e nos ouvintes.

Cheguei a imaginar, na minha imaginação de menina, que as páginas do livro eram os ouvintes da história que a professora lia nos nossos olhos. Isso mesmo: o livro era o ouvinte da história que a professora lia na gente. Nós éramos os livros, obras vivas, vivíssimas!

O tempo foi passando, passando...

Aqueles sentimentos provocados pela professora-leitora me ligaram eternamente à palavra escrita, e me fizeram trazer a leitura para esse território íntimo de nossas vidas, onde só circula o que é essencial-como, por exemplo, a amizade.

(Francisco Marques, Olhos de Ouvinte) 


\section{RESUMO}

O presente trabalho apresenta a compreensão da relação entre professor e alunos como aspecto fundamental da prática pedagógica. Considerando o processo de ensino-aprendizagem como um processo relacional, constituído por uma dimensão subjetiva, entende-se que é de fundamental importância a consideração das singularidades dos alunos no espaço social da sala de aula. Sendo assim, esta pesquisa propôs-se investigar as formas como uma professora buscava conhecer as especificidades dos alunos na dinâmica relacional da sala de aula, bem como identificar de que maneira esse conhecimento orientava a organização do trabalho pedagógico. O estudo foi fundamentado teoricamente pela perspectiva histórico-cultural de Vigotski e pela teoria da subjetividade numa perspectiva cultural-histórica, de González Rey. O processo investigativo foi ancorado nos princípios da Epistemologia Qualitativa, de González Rey (2005), que pressupõe o processo de produção do conhecimento a partir de um caráter construtivo-interpretativo, singular e dialógico. A pesquisa foi realizada a partir de um estudo de caso em uma turma do $1^{\circ}$ ano do Ensino Fundamental de uma escola pública do Distrito Federal, em que buscou-se conhecer as bases da relação professora-alunos, os processos comunicativos e a articulação da constituição subjetiva da professora com as dinâmicas relacionais desenvolvidas na sala de aula. Foram utilizados como instrumentos de pesquisa: observação participante das aulas e das coordenações pedagógicas; entrevistas; dinâmicas conversacionais; complemento de frases; análise documental e redação. A construção interpretativa indicou que as formas de a professora se relacionar com os alunos tinham como base suas escolhas pedagógicas, seu sistema de valores e crenças, suas concepções sobre aprendizagem e infância e suas produções subjetivas em relação a seus alunos. As maneiras como a professora buscava conhecer seus alunos não estavam baseadas em ações específicas, mas na transformação da sala de aula em um espaço relacional, aberto ao diálogo e que abria espaço para o envolvimento emocional dos alunos e para que eles se posicionassem como sujeitos. A relação dialógica entre professora e alunos era base para o desenvolvimento do trabalho pedagógico e, ainda, para o desenvolvimento dos alunos e da própria professora. $\mathrm{O}$ modo de funcionamento da turma estava fortemente marcado pela constituição subjetiva da professora. A partir das informações construídas, se reconhece a complexidade da relação professor-aluno, que é composta por uma multiplicidade de fatores que se articulam de maneira singular, e a necessidade de se ampliar as discussões sobre a dimensão subjetiva que constitui o espaço social da sala de aula.

Palavras-chave: relação professor-aluno; sala de aula; organização do trabalho pedagógico; singularidades; relação dialógica; teoria da subjetividade. 


\begin{abstract}
This paper presents the connection between teacher and students as fundamental in pedagogical practice. Considering the teaching-learning process as a relational process, composed of a subjective dimension, it is of our understanding that it is of major significance consider the singularities of students in the social space that is the classroom. Therefore, the research aims to investigate the ways a teacher got to know the particularities of her students in the relational dynamic of classroom, such as identify how this information guided the organization of her pedagogical work. This study was based on the cultural-historical theory of Vigotski e on the theory of subjectivity developed by González Rey. The investigative process was based on the principles of the Qualitative Epistemology, by González Rey (2005), that assume the process of construction of knowledge from the constructive-interpretative, singular and dialogical aspects. The study was made from a case study of a class of $1^{\circ}$ year of the fundamental course at a public school in Distrito Federal, where aimed to understand the basis of the relationship between teacher and students, the communicative process and the coordination between the teacher's subjectivities and the relational dynamics developed in class. As research material were used: participative observation of the classes and pedagogical reunion; interviews; dynamic talks; phrases complementarity; documental analysis and essays. The interpretative construction indicated that the form that the teacher connected with her students had for base her pedagogical choices, value system and believes, her conceptions about learning and childhood and her subjective output. The ways that the teacher had to know her students weren't based on specific actions, but on the transformations of the classroom into a relational space, open to the dialogue and to the emotional involvement of the students so they could show theirselves as individuals. The dialogical relations between teacher and students was the basis for the development of the pedagogical work and, yet, for the development of both students and teacher. The way the class operated was strongly marked by the constitution of the teacher subjectivity. Based on these details, the complexity of the teacher-student relation is recognized, composed by the variety of factors that are articulated in their own way, and the need of widen the discussion about the subjective dimension that constitute the social space of the classroom.
\end{abstract}

Keywords: teacher-student relation; classroom; organization of the pedagogical work; singularities; dialogical relation; theory of subjectivity. 


\section{SUMÁRIO}

1. INTRODUÇÃ

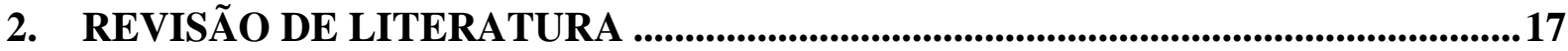

2.1. Primeiro momento: a produção científica em periódicos da Scielo Brasil e Capes.....17

2.2. Segundo momento: a produção científica no Repositório Institucional da Universidade de Brasília.

3. A PERSPECTIVA HISTÓRICO-CULTURAL DE VIGOTSKI.............................31

4. A TEORIA DA SUBJETIVIDADE NUMA PERSPECTIVA CULTURAL-

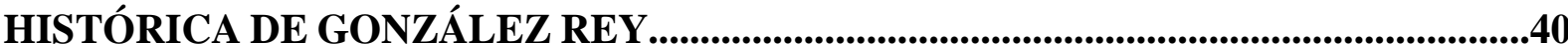

4.1 Contribuiçõespara a compreensão da educação e dos processos relacionais na sala de aula .46

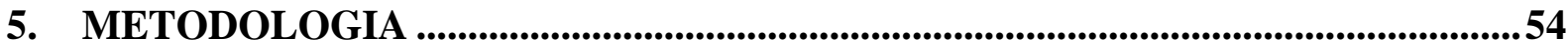

5.1 Epistemologia Qualitativa, de González Rey ........................................................54

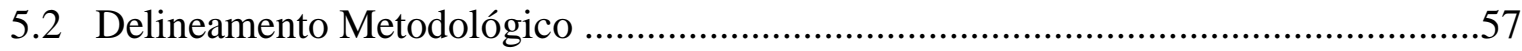

5.2.1 Escolha dos participantes e construção do cenário social da pesquisa .........58

5.2.2 Produção da Informação - instrumentos da pesquisa....................................60

6. O PROCESSO CONSTRUTIVO INTERPRETATIVO: A RELAÇÃO PROFESSORA-ALUNOS COMO BASE DO CONTEXTO PEDAGÓGICO ..................66

6.1 Bases que constituem a relação professora-alunos .77

6.2 Aspectos da constituição subjetiva da professora Alice e sua articulação para a compreensão das relações estabelecidas com os alunos

6.3 Síntese integrativa dos aspectos analisados: respondendo aos objetivos da pesquisa 138

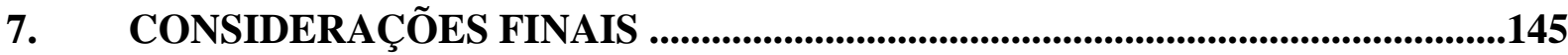

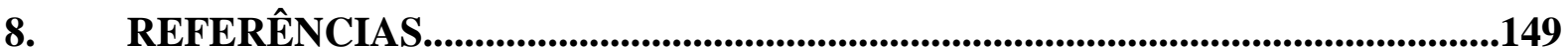

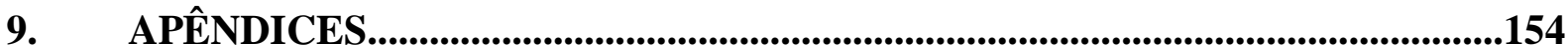

APÊNDICE A - Carta de apresentação..........................................................154

APÊNDICE B - Termo de Consentimento Livre e Esclarecido...............................155

APÊNDICE C - Eixos da entrevista com a professora..........................................156

APÊNDICE D - Complemento de frases.......................................................................158

APÊNDICE E - Redação ..................................................................................161 
APÊNDICE F - Dinâmica conversacional com os alunos.........................................162 


\section{INTRODUÇÃO}

Desde o nascimento, todas as crianças entram em contato com um mundo cheio de significados e sentidos com formas de organização criadas ao longo da história da humanidade. O acesso a esse mundo se dá através da interação que inicialmente está fortemente atrelada à figura da mãe - ou da pessoa que representa esse papel - e da família. Com o passar do tempo, esse processo interativo se expande a outras pessoas e espaços sociais, incluindo familiares, amigos dos familiares, vizinhança, comunidade, igreja, escola, dentre outros contextos. É bem verdade que todas as relações estabelecidas ao longo da vida podem influenciar o desenvolvimento de uma pessoa, entretanto a escola, entendida como espaço institucionalizado, organizado sistematicamente para a formação plena do indivíduo, tem um diferenciado papel nesse processo.

A organização do sistema educativo requer que as pessoas passem bastante tempo de suas vidas no espaço escolar. Durante um grande período de tempo e ocupando o mesmo espaço, alunos, professores e demais servidores, que participam do contexto escolar com todas as suas características, histórias de vida e diferenças, se relacionam e se implicam mutuamente. Entretanto, há um tipo de relação que não ocorre apenas espontaneamente ou pelo simples fato de estarem em um mesmo lugar: a relação entre professor e alunos. Tal relação ocorre durante o processo de ensino-aprendizagem que é algo intencional e possui formas sistemáticas de organização. É claro que a relação entre professor e alunos não se limita aos momentos sistematicamente organizados, entretanto as maneiras como os processos relacionais são construídos no espaço da sala de aula têm fundamental relevância no desenvolvimento do processo educativo.

Ao longo dos anos, as formas como a sociedade compreendia a educação, o desenvolvimento humano e a aprendizagem tiveram impacto nas maneiras de organização das práticas pedagógicas que refletiram no tipo de relação construída no espaço da sala de aula. Esse movimento se deu muitas vezes com a negação da diversidade e a busca por uma padronização que favorecia a reprodução de desigualdades sociais a partir da exclusão das pessoas que não se encaixavam nos modelos estabelecidos. Fazendo uma crítica a essa situação e combatendo a exclusão, movimentos sociais, pesquisadores e educadores têm lutado para garantir não apenas o acesso de todos às escolas, mas, ainda, a qualidade da educação nestes espaços. Apesar dessas lutas e de constantes estudos e discussões sobre as práticas excludentes das instituições educativas, muitos desafios ainda se apresentam. 
A ação didática é uma prática escolar social orientada por determinadas concepções que sugerem ideais de escola e de sociedade. Numa abordagem tradicional de educação, por exemplo, o ato de ensinar pode ser associado à exposição verbal do professor, no qual cabe aos alunos receber e proceder a fixação e reprodução dos conteúdos. Se a aprendizagem é associada à memorização ou armazenamento de informações, a relação professor-aluno provavelmente será vertical e unilateral. Por outro lado, se a aprendizagem for associada à capacidade de fazer descobertas e relações entre as ideais, caberá ao professor organizar as experiências escolares e as relações sociais de modo a permitir que o aluno atue na realidade e construa conhecimentos. E, ainda, se se entende que a educação é o caminho de transformação da realidade, o processo de ensino-aprendizagem deverá ocorrer numa relação dialógica, a partir da problematização da prática social e da mediação pelo diálogo. (FARIAS ET AL, 2008)

Entretanto, essa relação entre os ideais de escola e sociedade e a prática pedagógica não se dá de maneira direta e unilateral. Devido à própria dinâmica do espaço escolar em um mesmo tempo histórico e contexto social, por exemplo, coexistem no trabalho docente diversos modos de agir e de se relacionar com os alunos, modos estes que não são neutros em relação aos fins educativos, mas que nem sempre são assumidos de forma consciente e intencional.

A compreensão que o professor tem acerca da aprendizagem e, mais especificamente, do aluno tem diversas implicações para o seu trabalho pedagógico. Considerar a turma apenas de maneira coletivizada, desconsiderando os sujeitos que dela fazem parte, bem como suas singularidades no processo de aprendizagem pode dificultar o percurso escolar de muitas crianças. Segundo Tunes, Tacca e Bartholo (2005), para essas crianças às vezes bastaria apenas um olhar especial através de um momento compartilhado para que seu percurso de desenvolvimento fosse compreendido de modo a possibilitar ao professor a proposição da ajuda necessária, incentivando assim o avanço para o próximo passo.

Para Farias et al (2008, p. 156), a aula pode ser entendida como "um espaço-tempo coletivo de construção de saberes, lócus de produção de conhecimentos que pressupõe a existência de sujeitos que se inter-relacionam, se comunicam e se comprometem com a ação vivida." A aula se constitui como espaço privilegiado para o processo de aprendizagem, onde a partir do diálogo, dos conflitos e negociações, professor e alunos podem desenvolver o trabalho que lhes compete. Ainda, a aula deve se constituir como possibilitadora de desenvolvimento tanto do aluno, como do professor. Neste sentido, a aula é espaço de encontros e trocas.

A comunicação é constitutiva desse espaço de encontros e trocas, pois é o canal que possibilita a relação entre os sujeitos do processo educativo. Este canal não se dá apenas através 
das verbalizações e mensagens diretas, mas de todo o contexto não-verbal - gestos simbólicos, olhares, silêncio - onde determinada mensagem é transmitida. Para possibilitar o desenvolvimento, a sala de aula deve ser organizada de modo a tornar-se um ambiente comunicativo, onde o diálogo seja a base para a participação e as negociações necessárias à aprendizagem.

Os modos como os processos comunicativos são construídos na sala de aula influenciam o posicionamento do aluno frente ao conhecimento e, ainda, a aproximação entre professor e alunos, que permitirá que o primeiro conheça as reais necessidades do segundo. A comunicação, além de ser via essencial para os processos de pensamento envolvidos na construção do conhecimento, possui um valor emocional que pode dificultar ou favorecer o desenvolvimento da prática pedagógica.

Também segundo Neto (2006), a prática pedagógica pode ser entendida como uma relação entre os sujeitos pedagógicos e o conhecimento, onde a relação professor-aluno aparece como um elemento central dessa relação. Uma primeira característica desta relação pedagógica é ser assimétrica, pois alunos e professores se encontram em posições distintas frente aos saberes sociais e acadêmicos e, ainda, frente às representações, valores e concepções de mundo. $\mathrm{O}$ autor destaca que a relação pedagógica possui um caráter público e um caráter privado. $\mathrm{O}$ caráter público se refere aos elementos institucionais como o currículo, a organização estrutural dos níveis de ensino, a carga horária, os materiais didáticos, dentre outros. Já o caráter privado se refere à "intimidade" da sala de aula, onde professor e alunos vão construindo um estilo próprio de se relacionar no contexto pedagógico.

Na construção deste estilo próprio de se relacionar entram em cena as subjetividades de professor e alunos; aspectos de suas histórias de vida e de experiências anteriores, tanto no campo educacional, quanto em outros contextos; aspectos relativos aos modos de conceber a si mesmo, o outro e o processo de ensino aprendizagem; aspectos simbólicos e emocionais. Todos esses aspectos compõem uma dimensão subjetiva que é constitutiva das relações entre professor e alunos, dimensão esta que tem sido pouco considerada nas práticas pedagógicas. Considerar a dimensão subjetiva na dinâmica relacional da sala de aula supõe reconhecer a diversidade, os modos singulares de cada aluno lidar com o conhecimento e com o outro para, assim, organizar o trabalho pedagógico de modo a atender todos os alunos concretos, reais, em suas necessidades e potencialidades.

Lunardi-Mendes (2005) destaca que muitas vezes o trabalho pedagógico não é organizado de modo a considerar a diversidade, o que pode levar muitos alunos a processos de exclusão. Algumas das características desse tipo de organização pedagógica destacadas pela 
autora são: proposição de atividades que desconsideram o sentido e o significado para os alunos, quando a maior preocupação está em como se faz e não em como se aprende; realização de práticas homogeneizadoras que consideram que o processo da aprendizagem ocorre da mesma forma para todos os sujeitos; direcionamento das práticas centradas no coletivo, onde o aluno não tem alternativa a não ser se adaptar à forma como o trabalho escolar está organizado; consideração de que a diferença dos alunos é um empecilho ao trabalho pedagógico. Essas características não são encontradas apenas em situações pontuais e específicas, pois por vezes demonstram uma prática hegemônica nas instituições escolares.

A partir da minha experiência profissional, de conversas realizadas nos momentos de coordenação pedagógica e de observações realizadas em pesquisas anteriores foi possível notar que alguns professores pouco sabem sobre os processos de aprendizagem de seus alunos, seus interesses e particularidades, muitas vezes, restringindo o conhecimento sobre os mesmos aos momentos formais de avaliação.

Nos momentos de organização do trabalho pedagógico, percebe-se que o currículo aparece como orientador único das práticas pedagógicas que são definidas com base nos conteúdos, muitas vezes sem a consideração das formas como os alunos aprendem. Durante o planejamento há pouca discussão sobre as especificidades dos alunos e uma maior preocupação com a seleção de atividades padronizadas que frequentemente são direcionadas com a consideração da turma de maneira coletivizada. No momento de realização dessas atividades padronizadas, muitas vezes, nota-se um espaço limitado para os processos relacionais e o desenvolvimento de práticas dialógicas que permitam ao professor conhecer as singularidades de seus alunos.

Não se trata de desconsiderar os aspectos operacionais envolvidos no processo de ensino-aprendizagem, mas de se ter clareza que o direcionamento das aulas não pode estar desvinculado dos sujeitos que dela fazem parte. Para González Rey (2006), considerar o sujeito que aprende leva o professor a reconhecer o caráter singular do processo de aprender, compreendendo a aprendizagem como um processo da subjetividade, em que o sujeito não aprende apenas como intelecto, mas como sistema complexo. Segundo o autor:

[...] não existirá sentido subjetivo em uma atividade despersonalizada; portanto, o maior inimigo da aparição dos sentidos subjetivos na aprendizagem será a aprendizagem padronizada, centrada em exigências externas que impedem o aluno de tornar-se sujeito de seu percurso na aprendizagem. (GONZÁLEZ REY, 2006, p. 39)

A sala de aula se apresenta como espaço privilegiado de relações interpessoais, principalmente nos anos iniciais do Ensino Fundamental onde o professor é responsável por 
uma turma por cinco horas ininterruptas (no caso do Distrito Federal), no entanto os fatos citados anteriormente indicam que, mesmo assim, pode acontecer um distanciamento entre professores e alunos. Por outro lado, percebe-se iniciativas pessoais de professores que buscam alternativas para romper com o distanciamento na tentativa de conhecer e considerar as necessidades e singularidades dos alunos.

Compreendendo o processo de ensino-aprendizagem como processo relacional e a importância da consideração das singularidades dos alunos no espaço da sala de aula é que surge o interesse dessa pesquisa, pensada a partir das seguintes questões: de que maneira o professor busca conhecer seus alunos no contexto pedagógico? Que aspectos da relação permite que o professor se aproxime e conheça os alunos? Como o professor utiliza esse conhecimento sobre os alunos na prática pedagógica? As práticas pedagógicas decorrem da visibilidade que o professor tem dos alunos? Como se dão os processos comunicativos?

Diante dos expostos e das questões elencadas propõe-se a realização desta pesquisa na tentativa de compreender as diferentes maneiras com que os professores buscam conhecer seus alunos na dinâmica relacional da sala de aula e a interface desse processo com a organização do trabalho pedagógico. Apesar de muitos educadores assumirem a importância desse tema, percebe-se que o mesmo não está resolvido no cotidiano das práticas pedagógicas e nem foi enfocada na perspectiva teórica que o faremos. Sendo assim, a realização da pesquisa tem como justificativa a necessidade de compreender os processos relacionais entre professor e alunos na sala de aula a partir da complexidade inerente as relações humanas, inserindo a subjetividade como parte constitutiva dos indivíduos e das organizações sociais que eles fazem parte. A compreensão da sala de aula como espaço relacional e a consideração dos aspectos subjetivos que fazem parte do processo de ensino aprendizagem abre novas zonas de sentido para o entendimento da relação professor - aluno. Nesta perspectiva, pretende-se adotar uma forma diferente de produção do conhecimento, com bases epistemológicas que permitem o estudo da subjetividade e de realidades complexas e plurideterminadas, contempladas pela Epistemologia Qualitativa, desenvolvida por González Rey, que será melhor explicitada posteriormente.

Pretende-se realizar tal pesquisa em uma escola pública de séries iniciais do Distrito Federal, no contexto de turmas do Bloco Inicial de Alfabetização $\left(1^{\circ}, 2^{\circ}\right.$ e $3^{\circ}$ anos). Essa escolha se deve à compreensão de que este nível de ensino marca o início de uma maior formalização na dinâmica relacional da sala de aula, devido às exigências curriculares. A pesquisa será orientada pelos seguintes objetivos: 


\section{Objetivo Geral:}

- Investigar de que maneira a professora busca conhecer as especificidades dos alunos na dinâmica relacional da sala de aula, bem como identificar como esse conhecimento orienta a organização do trabalho pedagógico.

Objetivos Específicos:

1) Analisar o desenvolvimento das relações entre professora e alunos na sala de aula, identificando as bases pelas quais elas se constituem.

2) Identificar as formas como a professora age e cria canais comunicativos com a turma e com os alunos individualmente.

3) Conhecer aspectos que constituem a subjetividade individual da professora, bem como a articulação destes aspectos para a compreensão das relações construídas com os alunos.

A fim de orientar o leitor sobre a organização do trabalho segue breve explicação da estrutura dos capítulos. No primeiro capítulo será apresentada uma Revisão de Literatura sobre a relação professor aluno realizada em dois momentos: o primeiro no banco de dados da Scielo Brasil e Capes e o segundo momento no Repositório Institucional da Universidade de Brasília, mais especificamente nos programas de pós-graduação da Faculdade de Educação e do Instituto de Psicologia. Tal revisão foi realizada com o objetivo de conhecer a produção científica sobre o tema, os aspectos que têm sido privilegiados nas pesquisas, bem como identificar se os estudos a respeito dos processos interativos na sala de aula têm se preocupado em abordar a questão do olhar do professor às singularidades dos alunos.

No segundo capítulo, será apresentado o primeiro referencial teórico da pesquisa: a perspectiva histórico-cultural de Vigotski e suas contribuições para a compreensão dos processos interativos. Serão analisadas as considerações do autor sobre o papel das interações sociais no desenvolvimento humano; a relação entre aprendizagem e desenvolvimento; a relação entre o contexto social e o desenvolvimento psicológico e as possíveis implicações para a compreensão das práticas relacionais na sala de aula.

No terceiro capítulo, será desenvolvido o segundo referencial teórico da pesquisa: a Teoria da Subjetividade numa perspectiva cultural-histórica, de González Rey. Num primeiro 
momento serão apresentadas as categorias gerais para o entendimento da teoria e, em seguida, as implicações para a educação e mais especificamente para a relação entre professor e alunos.

O quarto capítulo irá tratar das bases epistemológicas e metodológicas do trabalho, organizadas em duas partes. A primeira parte se refere à apresentação da Epistemologia Qualitativa, de González Rey, e suas considerações para a produção do conhecimento. Na segunda parte será descrito o delineamento metodológico, com apresentação da construção do cenário de pesquisa e dos instrumentos utilizados para a produção da informação.

No quinto capítulo apresentamos a construção interpretativa produzida a partir da pesquisa com as construções e interpretações sobre as formas de relação entre a professora e os alunos da turma investigada, bem como da constituição subjetiva da professora. Posteriormente, como conclusão, fazemos uma síntese integrativa dos aspectos analisados buscando responder aos objetivos da pesquisa e apresentamos as considerações finais com as principais contribuições do processo de pesquisa. 


\section{REVISÃO DE LITERATURA}

Este capítulo apresenta uma revisão de literatura realizada com o objetivo de conhecer as concepções, escolhas teóricas, epistemológicas e metodológicas com que o tema da relação entre professor e alunos vem sendo estudado. Além disso, houve ainda a intenção de identificar se os estudos a respeito dos processos relacionais na sala de aula têm se preocupado em abordar a questão do olhar do professor às singularidades dos alunos, objetivo mais amplo deste trabalho.

A revisão de literatura foi feita em dois momentos: inicialmente em periódicos, especialmente artigos científicos provenientes das bases de dados Scielo Brasil e Capes, em que houve seleção dos trabalhos e organização em categorias para análise; posteriormente, procedeu-se à pesquisa no Repositório Institucional da Universidade de Brasília, especificamente em teses e dissertações do Programa de Pós-graduação da Faculdade de Educação e do Instituto de Psicologia. Cada um desses momentos será apresentado a seguir, com considerações sobre os trabalhos selecionados.

\subsection{Primeiro momento: a produção científica em periódicos da Scielo Brasil e Capes}

Utilizamos para a pesquisa bibliográfica na base de dados Scielo e Capes os seguintes descritores: relação professor aluno; interação professor aluno; singularidade dos alunos. Os critérios para o levantamento foram: tipo de trabalho (apenas artigos); cronológico (2008 a 2015); nível de ensino (anos iniciais do Ensino Fundamental) e metodológico (artigos que apresentavam pesquisas empíricas).

A partir de uma leitura inicial dos resumos e seguindo os critérios estabelecidos foram selecionados onze artigos para análise. Após essa seleção procedeu-se a organização dos mesmos em uma tabela que continha informações gerais dos artigos, tais como: título, autor (es), ano de publicação, periódico, objetivo e procedimentos metodológicos. Essa tabela permitiu um mapeamento inicial que facilitou a visualização das opções de estudo dos trabalhos e posterior organização em categorias para análise.

Após o mapeamento inicial já descrito na metodologia e leitura integral de todos os trabalhos, foram elaboradas as seguintes categorias para análise dos estudos, de acordo com as maneiras como o tema foi abordado pelos autores: 1) a relação entre professor e alunos a partir da perspectiva de um desses sujeitos; 2) a relação entre professor e alunos na prática 
pedagógica; 3) articulação da relação entre professor e alunos a temáticas específicas. É importante ressaltar que é possível que alguns estudos discutam também questões abordadas em outras categorias, entretanto tal organização se deu considerando o foco central dos trabalhos.

A seguir cada categoria será apresentada a partir da exposição do tema, da metodologia e dos principais resultados de cada trabalho analisado. Ao final, trazemos algumas considerações das discussões suscitadas.

\section{1) A relação entre professor e alunos a partir da perspectiva de um desses sujeitos}

Os artigos aqui elencados apresentam, basicamente, dois tipos de abordagem: estudos (SOARES ET AL, 2010; PETRUCCI ET AL, 2014; BARBOSA; CAMPOS; VALENTIM, 2011) que investigaram a percepção dos professores sobre suas relações com os alunos e os aspectos que podem influenciar tal percepção; e um estudo (MARTINELLI; SCHIAVONI, 2009) que abordou o tema a partir da perspectiva dos alunos e como eles percebem sua aceitação pelos professores.

No primeiro tipo de abordagem, o estudo de Barbosa; Campos; Valentim (2011) analisa a percepção do professor sobre a interação com os alunos e relaciona o tipo de interação estabelecida com as características dos discentes, em relação às variáveis: necessidade educacional especial, sexo, cor/raça, série e idade. O instrumento utilizado é a Escala de Relacionamento Professor-aluno, um instrumento padronizado e já referendado em estudos anteriores, que avalia a percepção dos professores sobre a qualidade do seu relacionamento com os alunos a partir de indicadores de conflitos e afinidade. Participaram da pesquisa 21 professores de seis escolas públicas da cidade de Juiz de Fora, Minas Gerais. Através de tabelas e gráficos, os pesquisadores analisam os dados de maneira quantitativa apresentando taxas de correlação entre o padrão de relação apontado pelos professores e as características dos alunos, indicando que há maior ocorrência de conflitos com alunos do sexo masculino e com alunos que possuem necessidades educacionais especiais. Os autores discutem o resultado da pesquisa a partir de um paralelo com estudos anteriores.

Em abordagem semelhante e utilizando o mesmo instrumento de pesquisa, Petrucci et al (2014) descreve procedimentos de adaptação e validação da Escala de Relacionamento Professor-Aluno versão reduzida (ERPA) para o contexto brasileiro. Tal escala, avalia a percepção dos professores sobre a qualidade do seu relacionamento com os alunos a partir de indicadores de conflitos e afinidade. Os relacionamentos considerados de qualidade seriam 
aqueles com alto índice de afinidade e baixo índice de conflitos. O estudo foi realizado em quatro escolas da cidade de Porto Alegre, com 31 professores de turmas do terceiro ao quinto ano do Ensino Fundamental. Os resultados são analisados a partir da frequência de ocorrência de variáveis e indicam que o relacionamento das professoras é mais positivos com as meninas do que com os meninos. Entretanto, o objetivo maior do artigo é demonstrar que a versão adaptada da ERPA é um instrumento útil para a avaliação da qualidade da relação professoraluno no contexto brasileiro.

O trabalho de Soares et al (2010) apresenta a relação entre a expectativa do professor e o desempenho dos alunos em atividades cognitivas. Inicialmente foi aplicado um questionário aos professores onde estes apontaram a quantidade de alunos que eles pensavam ser capazes de acertar determinados tipos de questões. Em seguida, esses dados foram comparados à situação real na resolução das questões pelos alunos e correlacionado às características dos discentes, indicando que a percepção dos professores é influenciada pela percepção do ambiente escolar e das características sociodemográficas dos alunos. A pesquisa foi realizada com professores e alunos da $4^{\mathrm{a}}$ série do Ensino Fundamental e como resultados apresenta que variáveis como gênero, raça e condição socioeconômica influenciavam na expectativa do professor, mesmo quando o aluno possuía determinada habilidade cognitiva.

Esses três estudos possuem aproximações teóricas e metodológicas, as quais se destacam: 1) a consideração de que a percepção dos professores é influenciada por determinadas características dos alunos, sejam físicas, comportamentais ou de condição social; 2) o entendimento de que essa percepção impacta a relação entre professor e alunos de maneira linear e direta; 3) a utilização de instrumentos padronizados, já referendados em estudos anteriores; 4) a discussão dos resultados não se dá apoiada no aprofundamento de um determinado referencial teórico, mas a partir de um paralelo com estudos anteriores.

A pesquisa de Martinelli; Schiavoni (2009) também utiliza um instrumento padronizado para avaliar as relações entre professores e alunos, porém neste caso foram os próprios alunos que preencheram uma escala de avaliação sobre a percepção que eles têm da sua aceitação pelos professores. Posteriormente, foi feita a correlação entre a percepção da aceitação pelos professores e a percepção da aceitação pelo grupo de colegas, de acordo com os grupos de amizades formados. A pesquisa foi realizada com 130 alunos da $3^{\text {a }}$ série do Ensino Fundamental e os resultados apontam que aqueles alunos que acreditam que seu professor tem uma percepção positiva sobre eles também apresentaram ser mais aceitos pelos colegas. Os autores discutem que as experiências de fracasso escolar podem levar os alunos a se perceber negativamente em relação aos demais, formando uma imagem deformada de si mesmos. 
2) A relação entre professor e alunos na prática pedagógica

Nesta categoria encontram-se os estudos (BENTO; SANTOS, 2014; TACCA; BRANCO, 2008; TACCA; GONZÁLEZ REY, 2008; CASTRO, 2011) que privilegiam a análise dos processos relacionais entre professores e alunos a partir da prática pedagógica, adentrando o espaço da sala de aula para discutir aspectos múltiplos da relação. Não há uma orientação única para os estudos aqui selecionados, sendo que alguns apresentam uma análise mais voltada a aspectos comportamentais e outros uma abordagem mais interpretativa em relação às dinâmicas relacionais.

O artigo de Bento; Santos (2014) realiza um estudo analisando as atitudes de professores em sala em aula. Os comportamentos e atitudes dos professores com os alunos foram analisados a partir de uma tabela contendo categorias definidas previamente, tais como: cuidado, querer bem, respeito, ambiente favorável, atitudes de exemplos, desafios aos alunos, dentre outras. A pesquisa foi realizada com quatro professores e suas respectivas turmas de anos iniciais do Ensino Fundamental. Como resultado os autores descrevem alguns comportamentos observados em cada variável elencada e discutem que os docentes devem estar atentos aos seus gestos e posturas, pois estes influenciam não apenas no processo de aprendizagem, mas podem deixar marcas nas histórias de vida dos alunos.

Para além da abordagem com o foco nos comportamentos, o trabalho de Tacca; Branco (2008) apresenta um estudo que analisa os processos de sentido e significação dos alunos em relação a diferentes aspectos da experiência escolar. Apoiada na perspectiva histórico-cultural, a pesquisa é realizada em duas turmas de $2^{\mathrm{a}}$ série do Ensino Fundamental e analisa os processos relacionais de duas professoras com um grupo de alunos com dificuldades de aprendizagem, identificados pelas docentes. Assumindo uma metodologia qualitativa, a partir de observações, entrevistas, realização de atividades estruturadas e grupos de discussão as autoras apontam que as crenças dos professores e as estratégias comunicativas podem favorecer ou dificultar o processo de ensino-aprendizagem. A partir de uma análise microgenética, o estudo destaca que as diferenças entre as duas professoras investigadas não reside na utilização de materiais pedagógicos, mas na criação de ações mediadoras que podem proporcionar novos processos de significação pelos alunos. As autoras apontam que esses processos de sentido e significação dos alunos estão apoiados na metacomunicação e na unidade cognição-afeto.

Em perspectiva semelhante, o artigo de Tacca; González Rey (2008) investiga como os sentidos subjetivos se manifestam e estão na base dos processos de aprendizagem dos alunos. Utilizando como aporte teórico e epistemológico a Teoria da Subjetividade e a Epistemologia 
Qualitativa, de González Rey, os autores analisam processos interativos entre uma professora e dois alunos da $4^{\mathrm{a}}$ série do Ensino Fundamental. A partir de uma análise construtivointerpretativa os autores buscam compreender a configuração subjetiva de cada um dos alunos. Como resultado, apontam que nos dois alunos são produzidos sentidos subjetivos configurados não apenas pelas atividades escolares, mas na vida social das crianças, que é inseparável de sua condição subjetiva. Os autores problematizam o fato de os professores considerarem a sala de aula apenas em termos instrumentais e não como espaço de comunicação que pode ajudar o aluno em seu desenvolvimento subjetivo. $\mathrm{O}$ estudo aponta para a necessidade dos professores considerarem a dimensão do sentido subjetivo na sala de aula para construir estratégias de trabalho que favoreçam a superação dos problemas que afetam a aprendizagem, sendo o diálogo um importante princípio nesse processo.

Esses dois artigos avançam em relação aos anteriores por investigarem não apenas aspectos comportamentais, mas os processos de sentido envolvidos na dinâmica relacional da sala de aula. Além disso, em termos metodológicos os autores se preocupam em compreender os fenômenos de maneira mais aprofundada, não se atendo apenas a análises descritivas e discutindo os processos relacionais de maneira dinâmica e interpretativa. $\mathrm{O}$ artigo de Tacca; González Rey (2008) tem particular interesse para nossa construção por considerarmos a dimensão subjetiva como constituinte dos processos relacionais que se estabelecem no cotidiano escolar.

Também apresentando uma abordagem interpretativa, Castro (2011) traz como tema a estigmatização da interação entre professores e alunos observada em conselhos de classe. Utilizando a metodologia da etnografia, o autor realizou visitas semanais a uma turma de $4^{\text {a }}$ série e bimestrais às reuniões de Conselho de Classe. A partir das análises das reuniões observadas em articulação com as situações da sala de aula, o autor discute que os alunos que não se encaixavam nos padrões normativos da escola recebiam um estigma e um controle por parte do professor que tornava essa marca visível em todo o meio escolar. Destaca que na maioria das vezes os professores recorrem ao histórico comportamental, familiar e de saúde mental dos alunos para justificar sua percepção negativa sobre os mesmos. Discute que esse processo gera exclusão dos alunos e que é fundamental o debate e a valorização das diferenças na escola. 
3) Articulação da relação entre professor e alunos a temáticas especificas

Nesta categoria encontram-se os estudos (ROCHA; CARRARA, 2011; LAMAS; FREITAS; BARBOSA, 2013; ROSEK; SERRA, 2015) que articulam a relação entre professor e alunos a temáticas específicas, tais como: bullyng, dificuldades de aprendizagem e formação ética. Os estudos apresentam procedimentos metodológicos diversos, alguns investigam as relações no contexto da sala de aula, enquanto outros analisam a partir da perspectiva de um dos sujeitos envolvidos.

O artigo de Rocha; Carrara (2011) defende a relação entre professores e alunos como forma de desenvolver a formação ética das crianças para a cidadania. Nesta perspectiva, a pesquisa avalia o efeito de um programa instrucional desenvolvido com duas professoras de primeira série do ensino fundamental. Este programa tinha o objetivo de permitir que as professoras melhorassem as habilidades de estimular o aluno no sentido deles desenvolverem comportamentos de habilidade social, visando uma formação ética. A partir de discussões teóricas com as professoras e instrução no desenvolvimento de comportamentos como elogiar e dar feedback positivo aos alunos, avaliou-se que o programa permitiu o avanço nas habilidades requeridas. A avaliação tanto do programa quanto das professoras foi realizada a partir de um instrumento padronizado (Inventário Multimídia de Habilidades Sociais para Crianças), já referendado em estudos anteriores, onde os comportamentos e reações eram classificados em mais ou menos habilidosos. Os resultados sugerem que a intervenção com as professoras foi efetiva na promoção dos comportamentos considerados socialmente habilidosos e na redução de comportamentos agressivos nas crianças. Apesar de apresentar um modelo de intervenção onde as professoras deveriam rever suas práticas, novamente percebe-se a tendência de padronizar os processos relacionais, entendido a partir de elementos comportamentais.

Lamas; Freitas; Barbosa (2013) investigam a associação entre bullyng e relação professor-aluno em 443 estudantes do quarto ao nono ano do Ensino Fundamental. A pesquisa é realizada a partir de um questionário que tinha o objetivo de identificar papeis, contextos e formas de agressões sofridas pelos alunos e da Escala da Relação Professor-aluno (ERPA), que avalia conflitos e afinidades dos alunos com os docentes. Os autores apresentam uma análise quantitativa a partir da frequência das repostas dos alunos e, em seguida, discutem os dados. Como resultados, tem-se que as variáveis bullyng e relação professor-aluno não se articulam de maneira uniforme nos anos escolares investigados, sendo que uma relação positiva e de afinidade com os professores tende a diminuir ao longo das séries. Os autores destacam que os 
alunos considerados agressores têm uma percepção mais negativa quanto às suas relações com os professores, enquanto os alunos considerados vítimas possuem um baixo nível de percepção da intervenção do docente quando as agressões ocorrem. O estudo alerta que o bullyng é um fenômeno com múltiplas influências, entretanto a maneira como a relação entre professores e alunos se constitui reflete na procura ou não por ajuda daqueles que sofrem agressões. As discussões apontam para a necessidade de se capacitar os docentes de modo que eles previnam e combatam o bullyng na escola.

Os dois estudos possuem semelhanças por considerar que a relação entre professor e alunos é fundamental para o desenvolvimento de outros aspectos, além de apresentarem a discussão das pesquisas a partir de comparação com estudos anteriores já publicados.

Rosek, Serra (2015) apresenta um estudo que teve o objetivo de conhecer as dificuldades de aprendizagem apresentadas por crianças e adolescentes que receberam atendimento psicopedagógico em um serviço de apoio da Universidade do Rio Grande do Sul. A partir da análise de conteúdo dos prontuários dos alunos atendidos, os autores destacam que há um elevado índice de dificuldades afetivo-emocionais apresentadas por essas crianças. O estudo aponta para a importância de compreender o papel dos processos emocionais nas dificuldades de aprendizagem e da necessidade de uma formação docente que passe pela problematização da relação professor-aluno. Os autores sugerem que essa relação seja baseada na construção do diálogo, a partir da escuta do outro e do respeito à história do aluno.

Apesar de não abordar a relação entre professor e alunos como tema central, consideramos relevante a inserção desse estudo por abordar os processos emocionais envolvidos na aprendizagem, dimensão que tem sido desconsiderada tanto em pesquisas, quanto na prática pedagógica.

\section{Discussão}

Foi possível notar uma tendência de estudos que utilizaram instrumentos padronizados a partir da análise de características comportamentais da relação. Essa característica foi encontrada em cinco estudos (SOARES ET AL, 2010; PETRUCCI ET AL, 2014; BARBOSA; CAMPOS; VALENTIM, 2011; ROCHA; CARRARA, 2011; LAMAS; FREITAS; BARBOSA, 2013), que fazem parte de periódicos que têm como área principal a Psicologia. Esta situação pode estar relacionada a uma tradição positivista presente ainda hoje nas abordagens de pesquisa nas ciências humanas e sociais. $\mathrm{O}$ uso de instrumentos padronizados e considerados legítimos por já terem sido referendados em estudos anteriores demonstra uma 
necessidade de busca de objetividade, neutralidade e representação da pesquisa como processo empírico. Segundo González Rey (2005, p.39):

O uso de instrumentos nessa perspectiva tem, em sua base, uma definição comportamental que considera a psique como um conjunto de entidades observáveis no comportamento, omitindo completamente as dimensões de sentido e significação do estudado.

O autor tem definido essa tendência como uma epistemologia da resposta, onde a informação da pesquisa é produzida a partir da descrição e classificação das respostas dadas aos instrumentos utilizados. Quando as respostas são associadas a categorias definidas a priori pelo próprio instrumento em questão, não há espaço para expressão subjetiva dos participantes da pesquisa, tampouco para o processo construtivo do pesquisador. Este processo não permite vislumbrar o que está por trás do comportamento ou da fala, as crenças, valores, sentidos e significações que permitirão processos explicativos, e não mais apenas descritivos, para o problema estudado.

\subsection{Segundo momento: a produção científica no Repositório Institucional da Universidade de Brasília}

O levantamento bibliográfico de teses e dissertações do Repositório Institucional da Universidade de Brasília foi feito especificamente nos programas de pós-graduação da Faculdade de Educação e do Instituto de Psicologia, por já termos identificado no levantamento anterior que estas são as duas áreas (Educação e Psicologia) que mais apresentam pesquisas sobre o tema. Utilizamos como descritores os termos "relação professor aluno; interação professor aluno" e a seleção dos trabalhos foi feita a partir dos mesmos critérios já explicitados: trabalhos entre 2008 e 2015 e que trazem pesquisas realizadas nos anos iniciais do Ensino Fundamental. No programa de pós-graduação do Instituto de Psicologia, a partir do descritor inicial foram gerados 34 trabalhos e, após a leitura dos resumos, encontramos apenas três (duas teses de doutorado e uma dissertação de mestrado) que se encaixavam nos critérios elencados. Já no programa de pós-graduação da Faculdade de Educação, a pesquisa inicial indicou 84 trabalhos, sendo que apenas cinco (todos dissertações de mestrado) englobavam os critérios estabelecidos. Sendo assim, no total foram analisados oito trabalhos (duas teses e seis dissertações) que foram organizados a partir de categorias que serão explicitadas a seguir.

A leitura inicial dos resumos dos trabalhos que foram sugeridos a partir do levantamento indicou que havia um número reduzido de pesquisas que abordaram a relação entre professor e 
alunos como temática central. Sendo assim, foram selecionados trabalhos que estavam dentro dos critérios estabelecidos e continham aproximações com o tema. A análise dos trabalhos gerou a seguinte categorização: 1) a relação entre professor e alunos a partir da perspectiva dos professores; 2) articulação da relação entre professor e alunos a temáticas específicas; 3) a relação entre professor e alunos na prática pedagógica.

\section{1) A relação entre professor e alunos a partir da perspectiva dos professores}

Nesta categoria foi encontrado apenas um trabalho que aborda o tema da relação entre professor e alunos a partir da perspectiva dos professores, investigando suas percepções sem adentrar o espaço da sala de aula.

A pesquisa de Santos (2015) teve como objetivo compreender a relação afetivorelacional entre professor e alunos a partir do conceito psicanalítico de transferência ${ }^{1}$. Apoiado no referencial teórico da Psicanálise, a pesquisa foi realizada com 26 professores dos anos iniciais do Ensino Fundamental, por meio de um curso de extensão aprovado pela Secretaria de Estado de Educação do Distrito Federal. Foram utilizados como instrumentos a memória educativa de professores, que tem como base suas experiências escolares, e entrevistas semiestruturadas que foram analisadas a partir da análise de conteúdo. Como resultados, o autor apresenta que o cenário escolar está permeado por questões transferenciais que atravessam as relações provocando efeitos na constituição do sujeito como pessoa e como profissional. Discute que o fundamento da relação pedagógica reside no vínculo que se estabelece entre professor e alunos, sendo que tal vínculo é mobilizado pela transferência, e aponta para a necessidade dos docentes se apropriarem do conhecimento da Psicanálise para compreender melhor como se dão esses processos.

\section{2) Articulação da relação entre professor e alunos a temáticas específicas}

Nesta categoria encontram-se os trabalhos que discutem o tema da relação entre professor e alunos articulado a temáticas específicas, tais como: criatividade, desenvolvimento moral e auto-estima. Todos esses trabalhos foram provenientes do Programa de Pós-graduação do Instituto de Psicologia, sendo uma dissertação (LIBÓRIO, 2009) e duas teses (BARRIOS GONZÁLEZ, 2013; MIRANDA, 2008).

\footnotetext{
${ }^{1}$ Segundo Santos (2015, p.47), a transferência é um conceito da Psicanálise que explica o "deslocamento de sentido atribuído a pessoas do passado às pessoas do presente".
} 
Considerando que a educação implica na promoção do desenvolvimento e da aprendizagem, Libório (2009) argumenta que é fundamental que o trabalho pedagógico seja permeado por ações criativas. Neste sentido, sua pesquisa buscou investigar a relação professoraluno para compreender de que forma essas relações podem ser favorecedoras de um clima propício ao desenvolvimento da criatividade em sala de aula. O estudo foi realizado com professores e alunos de oito turmas de $5^{\mathrm{a}}$ série do Ensino Fundamental a partir de instrumentos variados, tais como: escala sobre clima favorável à criatividade, entrevista semi-estruturada, observações em sala de aula e gravações em vídeo. Os resultados sugerem que as turmas que apresentaram um clima mais favorável à criatividade eram aquelas que apresentavam interações professor-aluno de sintonia e cooperação com mais frequência. A autora discute ainda que as concepções dos professores sobre suas relações com os alunos são perpassadas pela noção de aluno ideal como aquele que segue as instruções e permanece em silêncio durante as aulas. Destaca que a expressão da criatividade é facilitada quando há um clima interativo de cumplicidade, confiança e empatia.

Barrios González (2013) apresenta um estudo que articula a relação entre professor e alunos ao desenvolvimento moral, apoiado na perspectiva sociocultural construtivista. Compreendendo que as crianças analisam e ressignificam suas próprias experiências nos diferentes contextos socioculturais, a pesquisa teve como objetivo identificar e analisar aspectos relevantes do discurso e argumentação e da dinâmica interativa entre um professor e um grupo de alunos, relacionada ao desenvolvimento moral. A pesquisa foi realizada em uma turma de $5^{\circ}$ ano do Ensino Fundamental de uma escola pública do Distrito Federal, a partir da análise microgenética de situações estruturadas, discussões com um grupo focal e entrevistas com o professor. Como resultados, a autora apresenta que no contexto investigado o desenvolvimento moral era visto de maneira equivocada, relacionado a um conjunto de normas e regras de disciplina. As análises apontaram uma relação assimétrica entre professor e alunos, onde o professor exercia papel central nas atividades, com poucos momentos de negociação e estabelecimento de regras sem discussão com o grupo, fatores que não favorecem o desenvolvimento moral dos estudantes. As discussões apontam para a necessidade de se problematizar o controle por parte dos docentes e melhorar suas competências em relação ao desenvolvimento moral do aluno.

A pesquisa de Miranda (2008) teve o objetivo de identificar mecanismos comunicativos e metacomunicativos ${ }^{2}$ nos processos de construção da auto-estima. A pesquisa foi realizada

\footnotetext{
${ }^{2}$ Segundo Miranda (2008) a metacomunicação se refere à comunicação sobre uma situação onde a interação ocorre, onde há um novo olhar sobre o conteúdo e as maneiras de se comunicar.
} 
com uma professora e seis crianças da $1^{\mathrm{a}}$ série do Ensino Fundamental de uma escola pública do Distrito Federal. Utilizando como instrumentos a observação de situações estruturadas e entrevistas e fazendo uma análise microgenética, a autora destaca que a interação comunicativa serena e respeitosa da professora nos momentos de intervenção ou advertência atuava de maneira colaborativa aos processos de construção de auto-estima das crianças. Além disso, a qualidade da mediação e a percepção da professora em não perder os feedbacks comunicacionais e metacomunicacionais com a turma foi importante para a manutenção e elevação da auto-estima. A autora discute que os encontros comunicativos e metacomunicativos entre professor e alunos podem possibilitar o desenvolvimento de habilidades sociais, afetivos, cognitivas, criativas e motoras.

Os três estudos possuem aproximações não apenas por sua articulação a temáticas específicas, mas por considerar que a relação estabelecida na sala de aula é fundamental para outros tipos desenvolvimento, para além da aprendizagem dos conteúdos curriculares.

\section{3) A relação entre professor e alunos na prática pedagógica}

Nesta categoria encontram-se trabalhos que discutem a relação entre professor e alunos na prática pedagógica, investigando as dinâmicas relacionais na sala de aula. Alguns desse trabalhos (ANJOS, 2014; RODRIGUES, 2014; FERREIRA, 2013; LIMA, 2008) possuem um enfoque maior na prática pedagógica, não abordando a relação como foco central, mas trazendo considerações relevantes para a discussão do tema.

Compreendendo a escola como contexto de desenvolvimento humano, Anjos (2014) analisa a prática pedagógica de três professores do $2^{\circ}$ ano do Ensino Fundamental, buscando compreender os aspectos da atuação dos docentes que se relacionam com o desenvolvimento de operações complexas de pensamento pelos alunos. Apesar do objetivo geral do trabalho não tratar explicitamente da relação entre professor e alunos, a temática é abordada a partir da análise do direcionamento das práticas pedagógicas. Embasada pela perspectiva históricocultural, a autora investiga o contexto escolar, as formas de planejamento dos professores, as escolhas pedagógicas e as estratégias de intervenção com os alunos. Destaca que a forma como os professores orientavam suas escolhas pedagógicas variava, sendo que apenas um professor orientava sua prática por conversas, discussões e negociações com os alunos, enquanto os outros compreendiam o desenvolvimento dos discentes relacionado prioritariamente à aprendizagem dos conteúdos escolares e conceitos. Consideramos relevantes as discussões da pesquisa sobre a organização do trabalho pedagógico baseada quase que exclusivamente nos 
conteúdos curriculares, onde a aprendizagem é relacionada à transmissão de conhecimentos de maneira padronizada e os sujeitos ficam em segundo plano.

Rodrigues (2014) discute a relação entre professor e alunos como uma relação que envolve tanto aspectos objetivos quanto aspectos intersubjetivos. Ancorada na perspectiva histórico-cultural de Vigotski e na abordagem da complexidade de Edgar Morin, a autora realiza uma pesquisa com três professoras de séries iniciais do Ensino Fundamental, destacando que a relação entre professor e alunos é marcada pelas expectativas dos docentes e pelas formas que os sujeitos significam as experiências do trabalho pedagógico. Percebeu-se que o discurso das professoras é marcado pela necessidade de controlar os alunos, onde a coerção aparece como aspecto recorrente. A autora ressalta que esse controle é uma forma das docentes lidarem com a heterogeneidade e complexidade que envolvem o processo de ensino-aprendizagem. Essa situação representa uma relação assimétrica entre professor e alunos, gerando uma dificuldade para o verdadeiro encontro na relação pedagógica.

Sobre a necessidade de o professor conhecer os processos de pensamento e aprendizagem dos alunos se situam ainda os trabalhos de Ferreira (2013) e Lima (2008). Ferreira (2013) investiga como o brincar permite que professor e aluno entrem em diálogo possibilitando que o professor conheça os modos de aprender e pensar dos alunos, principalmente aqueles que estão enfrentando obstáculos no processo de aprendizagem. Apoiada na perspectiva histórico-cultural e realizando uma pesquisa numa turma de $3^{\circ}$ ano do Ensino Fundamental, a autora destaca que o brincar pode provocar mudanças nos processos psíquicos da criança e que nos momentos de brincadeiras o aluno assume um papel ativo e, por isso, é um importante recurso pedagógico para o professor que busca fazer uma leitura dos processos de aprendizagem dos alunos. Apesar de a análise está centrada em um recurso pedagógico - o brincar - a autora salienta que as questões que configuram a relação professoraluno são decisivas para o processo de aprendizagem, onde o professor deve considerar a diversidade dos alunos.

Já o trabalho de Lima (2008) buscou identificar como o professor investiga o processo de aprendizagem dos alunos, compreendendo as concepções dos professores sobre avaliação e as formas como o diagnóstico psicopedagógico subsidia a prática pedagógica. Ancorada na Teoria da Subjetividade e na Epistemologia Qualitativa de González Rey, a autora realizou uma pesquisa com duas turmas de Ensino Fundamental e analisou que as professoras consideravam que a avaliação deveria ser realizada de maneira ampla e contínua, de modo que oferecesse meios para direcionar a ação pedagógica e as decisões sobre os alunos, entretanto havia a prevalência do foco da avaliação na verificação do conteúdo. Como resultado, apresenta que as 
professoras não alcançam uma consideração da subjetividade nos processos de aprendizagem dos alunos, entretanto em uma das professoras investigadas pôde-se perceber uma atenção para as singularidades e diferenças dos alunos. Na turma desta última o vínculo afetivo com os alunos, os processos comunicativos e os espaços relacionais favoreciam a problematização do pensamento e a significação do conhecimento. Neste sentido, destaca:

\begin{abstract}
A atenção do professor quanto à dinâmica relacional da sala de aula, percebendo-se, inclusive, como ator nesse cenário, pode oferecer-lhe significativos indicadores quanto à compreensão singular dos processos de aprendizagem de seus alunos, em que a produção de significados e sentidos sobre o conhecimento e a participação da subjetividade neste processo podem ganhar uma atenção especial. Nessas informações, o professor pode encontrar os elementos necessários à elaboração de estratégias interventivas que alcancem as necessidades individuais de cada aluno e favoreçam, consequentemente, a aprendizagem dos mesmos. (LIMA, 2008, p. 204)
\end{abstract}

Esse trabalho se aproxima da nossa concepção por entendermos de fundamental importância que o professor conheça os alunos na prática pedagógica, não apenas seus modos de pensar e agir relacionados diretamente à aprendizagem, mas também suas histórias de vida, suas experiências, seus principais contextos interativos, dentre tantos outros aspectos que se integram na constituição das singularidades dos alunos, que devem ser consideradas nas salas de aula.

\title{
Discussão
}

A revisão de literatura apresentada permitiu o acesso a trabalhos que discutiram a relação entre professor e alunos a partir de temáticas e perspectivas metodológicas distintas. Destacamos que por se tratar de tese e dissertações, estes trabalhos apresentam uma discussão teórica mais densa e aprofundada, além de apresentar perspectivas metodológicas com maiores possibilidades explicativas, que vão além da mera descrição. Consideramos que seria interessante que os resultados destes trabalhos fossem discutidos através de publicação de artigos em periódicos, possibilitando uma maior divulgação e circulação das pesquisas.

Ressaltamos a ausência de tese de doutorado sobre o tema, no período pesquisado, no Programa de Pós-Graduação da Faculdade de Educação. Considerando que a relação entre professor e alunos é um aspecto fundamental da prática pedagógica, objeto próprio da área da Educação, este fato pode indicar a necessidade de ampliação e aprofundamento de pesquisas na área.

Neste cenário, este trabalho assume uma preocupação em investigar as maneiras como os professores buscam conhecer as especificidades dos alunos, bem como identificar se esse 
conhecimento orienta a organização do trabalho pedagógico. Para isso, considera-se os processos relacionais entre professor e alunos a partir da complexidade inerente as relações humanas, entendendo a subjetividade como parte constitutiva dos indivíduos e das organizações sociais que eles fazem parte. Nesta perspectiva, adota-se uma forma diferente de produção do conhecimento, com bases epistemológicas que permitem o estudo da subjetividade e de realidades complexas e plurideterminadas. Nestes aspectos reside o valor teórico e metodológico deste trabalho, por possibilitar a construção de novas zonas de sentido sobre os processos relacionais entre professor e alunos na sala de aula.

Dessa forma, este estudo será fundamentado na articulação das considerações da perspectiva histórico-cultural de Vigotski e da Teoria da Subjetividade numa perspectiva cultural-histórica, de González Rey, utilizando como base epistemológica a Epistemologia Qualitativa, também de González Rey. A perspectiva histórico-cultural marca a relevância do meio cultural e social para a constituição psicológica, destacando a importância das interações sociais no desenvolvimento humano. Além disso, os estudos de Vigotski trazem novas bases para compreensão da subjetividade como um fenômeno culturalmente constituído, perspectiva que é desenvolvida por González Rey na Teoria da Subjetividade, a partir de uma nova representação da psique como sistema complexo que integra as dimensões cognitivas e emocionais. Tais perspectivas teóricas e epistemológicas serão apresentadas nos capítulos seguintes. 


\section{A PERSPECTIVA HISTÓRICO-CULTURAL DE VIGOTSKI}

Como um dos grandes expoentes da psicologia histórico-cultural, Vigostki preocupouse em tentar explicar como as características tipicamente humanas se formaram ao longo da história da humanidade e ao longo da vida das pessoas. Neste processo, estudou as relações entre as pessoas e seu meio social, buscando explicitar o relacionamento entre o homem e a natureza e as consequências psicológicas dessa relação. Influenciado pela perspectiva materialista-dialética, o autor buscou analisar as relações do homem com o meio natural a partir das mudanças provocadas pelo trabalho, articulando a história da espécie humana com o desenvolvimento pessoal.

Nesta análise, Vigotski (1998) criticou a psicologia de sua época, destacando a necessidade de se desenvolver uma nova psicologia. $\mathrm{O}$ autor fez críticas à psicologia subjetiva e suas bases idealistas, e a psicologia objetiva, com enfoque fisiológico e mecanicista. Defendendo que o desenvolvimento dos comportamentos humanos não se limita a um processo unicamente maturacional, mas ocorre por meio de transformações complexas e qualitativas. Considerou que o objeto da psicologia deveria ser o processo integral do comportamento humano, não apenas por seus componentes biológicos, mas também os psíquicos que são social e culturalmente constituídos e estão em constante processo de desenvolvimento e transformação. A psicologia, portanto, deveria estudar a natureza do psíquico de maneira dialética, a partir das ideias de gênese e desenvolvimento, reorganização estrutural e da análise de unidades dos processos psicológicos.

Vigotski (1998) fez ainda críticas incisivas aos métodos de investigação fragmentados, em que experimentos a partir da estrutura de estímulos-respostas serviam de base para a explicação de fenômenos mentais complexos que não podiam ser reduzidos a condutas mecânicas. Para o autor, a compreensão dialética do desenvolvimento psicológico dos homens, que age sobre a natureza e cria as condições para sua existência modificando-a por meio de ferramentas culturais e, simultaneamente, modificando a si mesmo, requer novas metodologias de experimentação e análise em psicologia. Essas novas metodologias deveriam se basear em três princípios: a análise de processos em vez de objetos, a explicação dos fenômenos em vez da mera descrição e o abandono do caráter mecânico e fossilizado dos comportamentos, buscando a análise dinâmica das origens desses comportamentos. (VIGOTSKI, 1931) O estudo dos processos complexos humanos deveria ser baseado na análise dos sistemas, não em elementos fragmentados e isolados. 
Vigotski $(1998,2012)$ marca a relevância do meio social e cultural para a constituição psicológica, onde as trocas estabelecidas a partir das e nas interações sociais têm fundamental importância para o desenvolvimento humano. Neste processo, a linguagem tem papel relevante, pois introduz mudanças qualitativas nos processos psicológicos. Vigotski faz uma analogia entre o uso de signos e o uso de instrumentos, destacando que o primeiro funciona como instrumento psicológico devido a função mediadora que o caracteriza. As ações do homem na natureza não produzem transformações apenas no meio físico, mas transformam o próprio homem. Assim, da mesma forma que os instrumentos permitem ao homem o controle do comportamento externo, os signos possibilitam um meio de atividade interna, onde "a alteração provocada pelo homem sobre a natureza altera a própria natureza do homem.” (VIGOTSKI, 1998, p.73)

Este princípio só torna-se possível através da cultura, que para o autor pode ser entendida como uma produção humana que tem origem nas formas estruturadas de organização social. Os meios simbólicos da cultura permitem que o homem se aproprie dos meios culturais e possa modifica-los, modificando assim seu desenvolvimento psicológico que, dessa maneira, possui natureza social.

As elaborações de Vigotski representam um pensamento rico e dinâmico que não teve uma sequência harmônica e regular, pelo contrário, o autor teve momentos contraditórios e de idas e vindas no desenvolvimento de seu sistema teórico. Em alguns desses momentos, apesar de buscar uma relação dialética entre o individual/social entre o interno/externo, a explicação que ele elaborou acabou tendendo à operacionalização que ele tanto criticava. (GONZÁLEZ REY, 2012a)

Ao estudar a influência dos instrumentos no desenvolvimento da criança, Vigotski tentou ultrapassar as visões mecanicistas buscando levar em consideração as mudanças que ocorrem na estrutura interna das operações intelectuais da criança. Essas mudanças internas seriam possibilitadas pela relação social, onde a atividade simbólica desempenha uma função organizadora das atividades práticas da criança, que produz novas formas de comportamento e transformações psicológicas fundamentais para o desenvolvimento. Para o autor, a constituição da criança enquanto ser humano passa necessariamente pela mediação semiótica do outro, ou seja, a mediação através dos $\operatorname{signos}^{3}$ e significados. É através das interações sociais com o outro que as ações naturais da criança, bem como os objetos e instrumentos que a rodeiam, adquirem

\footnotetext{
${ }^{3}$ Os signos são as representações mentais das coisas do mundo. A semiótica é o estudo dos signos, dos modos como os homens significam o que os rodeia. (VIGOTSKI, 1998)
} 
significação. Esse processo permite que a criança se aproprie dos meios simbólicos do mundo cultural, que passa a tornar-se seu mundo.

O caminho do objeto até a criança e desta até o objeto passa através de outra pessoa. Essa estrutura humana complexa é o produto de um processo de desenvolvimento profundamente enraizado nas ligações entre história individual e história social. (VIGOTSKI, 1998, p. 40)

Para explicar esse processo de apropriação cultural que se dá a partir da mediação semiótica, Vigostki elaborou o conceito de internalização, que seria a reconstrução interna de uma atividade incialmente externa e socialmente vivenciada.

A internalização das funções culturais envolve a reconstrução interna da atividade psicológica que conduz ao desenvolvimento tipicamente humano. Para ilustrar esse processo Vigotski dá o exemplo do gesto de apontar da criança, o que inicialmente pode ser uma tentativa de pegar um objeto, a partir da ajuda de outra pessoa - que pode ser a mãe ou um familiar - a criança passa a compreender a função desse movimento, que deixa de ser orientado para o objeto e passa a ser orientado para a pessoa, como uma forma de estabelecer relação que possui um significado. Assim, o caminho do mundo até a criança passa, necessariamente, por outra pessoa.

O processo de desenvolvimento vai do social e cultural ao individual em uma relação dialética, onde todas as funções aparecem primeiro no plano social e em seguida no plano psicológico, ou seja, as funções psíquicas incialmente são relações sociais entre as pessoas.

Para González Rey (2012a), esse entendimento representa uma compreensão reducionista do autor, pois a relação direta entre o externo e interno representa uma compreensão operacional da psique. González Rey destaca que neste momento do desenvolvimento da compreensão da internalização das funções culturais, Vigotski acabou se distanciando dos princípios mais gerais de seu trabalho que rompiam com categorias objetivistas no entendimento das funções psicológicas.

Ao postular que o desenvolvimento ocorre primeiro no plano social para depois passar para o individual, Vigotski acaba por estabelecer uma relação linear e direta entre externo e interno, pois não explica como esse processo ocorre e não considera, neste momento, o caráter ativo da psique. Segundo González Rey:

Afirmar que passamos a ser nós mesmos através dos outros define uma relação linear do externo para o interno que é falsa, pois a ação dos outros não representa nada em si mesma, seus efeitos sobre a pessoa dependerão tanto de sua organização psicológica ao entrar em contato com esse outro, como do contexto em que se produz a ação do outro. Não existe outro "em si", que atue como universal nas diversas relações humanas; existe um outro produzido através de meus próprios processos subjetivos. 
O outro em sua universalidade só pode ser um outro instrumental que aparece diante de mim apenas por suas operações, mas sem nenhuma significação íntimo-emocional. (GONZÁLEZ REY, 2012a, p. 81)

Esse momento das elaborações de Vigotski, que representa uma compreensão mais operacional do funcionamento psicológico acabou sendo supervalorizado no Ocidente devido à interpretação de sua obra e a continuidade de alguns autores ligados ao pragmatismo norteamericano. Apesar desse critica, González Rey (2012a) salienta que em obras posteriores Vigotski retomou a preocupação com uma compreensão mais complexa da relação da criança com o mundo, destacando o papel das emoções no desenvolvimento. Neste momento, o autor busca se distanciar da relação direta entre o mundo e a constituição psicológica, trazendo elaborações que tentavam integrar a cognição e o afeto. Dentre essas elaborações estão os conceitos de situação social de desenvolvimento, vivência e sentido, que serão explicitadas mais adiante, ainda neste capítulo.

Na relação com o mundo e com as outras pessoas no processo de desenvolvimento, situam-se também os processos de aprendizagem. Vigotski abordou o problema da relação entre aprendizagem e desenvolvimento e suas especificidades nos processos educacionais. $\mathrm{O}$ autor postula que aprendizagem e desenvolvimento são processos inter-relacionados desde o primeiro dia de vida da criança, entretanto considera que a aprendizagem escolar é fundamental não apenas por ser a sistematização do conhecimento, mas por produzir mudanças qualitativas no desenvolvimento da criança. Para explicar a relação entre aprendizagem e desenvolvimento do contexto escolar ele elaborou o conceito de zona de desenvolvimento proximal.

Segundo essa abordagem, a criança possui pelo menos dois níveis de desenvolvimento: o nível de desenvolvimento real, que pode ser entendido como funções mentais que já possui desenvolvimentos completados, ou seja, aquilo que a criança é capaz de realizar de maneira independente; e o nível de desenvolvimento potencial, que representa aquilo que a criança é capaz de fazer com auxílio de outras pessoas, seja um adulto ou um parceiro mais experiente, e que é indicativo de um desenvolvimento prospectivo. A zona de desenvolvimento proximal é, portanto, a distância entre a zona de desenvolvimento real e a zona de desenvolvimento potencial, ou seja, representa processos que ainda estão em formação e pode delinear o desenvolvimento futuro da criança.

A aprendizagem, portanto, deve ser coerente com o nível de desenvolvimento da criança, no sentido do trabalho pedagógico ser orientado não para o desenvolvimento já alcançado, mas para o desenvolvimento de processos que estão em construção. Um ensino orientado para aquilo que a criança já desenvolveu torna-se ineficaz, pois não é capaz de dirigir 
o processo de desenvolvimento. Assim, “o ‘bom aprendizado’ é somente aquele que se adianta ao desenvolvimento." (VIGOTSKI, 2000, p. 117).

\begin{abstract}
a característica essencial da aprendizagem é que engendra a área de desenvolvimento potencial, ou seja, que faz nascer, estimula e ativa na criança um grupo de processos internos de desenvolvimento dentro do âmbito das inter-relações com outros, que na continuação são absorvidos pelo curso interior de desenvolvimento e se convertem em aquisições internas da criança. (VIGOTSKI, 1991, p. 115).
\end{abstract}

Nesta perspectiva, destaca a natureza social da aprendizagem, que será sempre dependente das relações com o outro. A aprendizagem não é a mesma coisa que o desenvolvimento, contudo, pode se configurar em processos de desenvolvimento das funções psicológicas culturalmente organizadas.

Este conceito tem sido muito difundido na área educacional e, por vezes, tem sido interpretado de maneira reducionista e instrumentalista. Sobre a apropriação desse conceito no campo educacional, Prestes (2010) problematiza que um dos motivos para tal banalização foram as traduções das obras de Vigostki. Sendo assim, a autora propõe uma nova tradução e interpretação do conceito, que segundo a autora deveria ser chamado de zona de desenvolvimento iminente.

\footnotetext{
a tradução que mais se aproxima do termo zona blijaichego razvitia é zona de desenvolvimento iminente, pois sua característica essencial é a das possibilidades de desenvolvimento, mais do que do imediatismo e da obrigatoriedade de ocorrência, pois se a criança não tiver a possibilidade de contar com a colaboração de outra pessoa em determinados períodos de sua vida, poderá não amadurecer certas funções intelectuais e, mesmo tendo essa pessoa, isso não garante, por si só, o seu amadurecimento. (PRESTES, 2010, 173)
}

Neste entendimento, marca-se a questão das possibilidades de desenvolvimento, pois a instrução por si só não é garantia que o desenvolvimento ocorra, mas realizada de maneira interativa e relacional, cria possibilidades potenciais para o desenvolvimento das funções psicológicas da criança, pois que tal desenvolvimento não está pré-determinado.

Para a perspectiva histórico-cultural, aprendizagem e desenvolvimento são processos interdependentes e essa relação não se refere apenas ao contexto escolar. Entretanto, compreendendo a escola como espaço de relações, pode-se entender que esse contexto social pode ir além da transmissão de saberes sistematizados e promover o desenvolvimento humano de maneira mais ampla e complexa.

Em sua primeira publicação, Psicologia Pedagógica, em 1926, Vigotski já demonstrava preocupação com a aprendizagem humana em contextos formais. Nesta obra, o autor destaca a plasticidade do comportamento humano e a importância das experiências pessoais dos alunos 
para a educação. Nesta perspectiva, o professor deve ser o organizador do meio social educativo, pois o mesmo não possui influência direta sobre o aluno. (VIGOTSKI, 2001) Para o autor, "se entendemos convencionalmente o meio social como o conjunto das relações humanas, é totalmente compreensível sua excepcional plasticidade, que o transforma em um dos recursos mais flexíveis da educação" (VIGOTSKI, 2001, p. 79). Destaca, ainda, que, no processo educativo, professor, alunos e meio social são ativos e que não se pode calcular ou prever os resultados dessa relação.

Na referida obra Vigostki ressalta que o professor deve provocar as emoções dos alunos, destacando que as emoções não são menos importantes que o pensamento e que devem estar presentes na estruturação do processo educativo. Apesar de ainda não desenvolver de forma densa a complexidade das relações entre emoção e pensamento, o autor já salienta a importância de a educação se preocupar com o aspecto emocional da personalidade.

Sobre a relação entre o contexto social e o desenvolvimento psíquico da criança, Vigotski desenvolveu o conceito de situação social de desenvolvimento, entendido como a combinação dos processos internos de desenvolvimento e das condições externas, que são diferentes em cada etapa e que influenciam a dinâmica de desenvolvimento psíquico (GONZÁLEZ REY, 2003). Vigotski (1934) tentou explicar a influência do ambiente no desenvolvimento psicológico da criança a partir de suas experiências emocionais, entendida como uma unidade de análise denominada pelo autor de perezhivanie (vivência). Esta categoria representa a unidade onde o ambiente é representado por meio das experiências emocionais e da maneira como a criança vivencia tais experiências, de acordo com suas características pessoais, seu nível de consciência sobre as situações vivenciadas e de como ela consegue elaborar internamente essas situações.

Para González Rey (2003), Vigotski não conseguiu desenvolver essa categoria de maneira mais aprofundada, entretanto a categoria representa uma tentativa de integrar em uma unidade o cognitivo e o afetivo, destacando a importância das emoções para o desenvolvimento psíquico. Ao abordar as relações entre o meio social e o desenvolvimento interno da criança a partir das vivências, sentimentos e emoções, o autor tenta articular as dimensões cognição e afeto no processo de desenvolvimento humano, dimensões estas que eram tratadas de maneira dicotômicas na psicologia da época e que, ainda hoje, tanto em elaborações teóricas quanto nas práticas pedagógicas não são assumidas como uma unidade. Entendendo a psique como um sistema, onde o social e o cultural são a base para o desenvolvimento, o autor buscou superar essa e outras dicotomias ao criticar os estudos que consideravam os processos psíquicos de maneira isolada e fragmentada. 
Em seu estudo sobre a relação entre pensamento e fala, o autor destacou que os métodos de análise das funções psicológicas utilizados pela psicologia de sua época eram indevidos por decompor processos complexos em elementos. Para explicar o equívoco cometido por esses métodos, Vigotski (2012) recorreu ao exemplo da água, esclarecendo que a análise dos elementos químicos - hidrogênio e oxigênio - em separado não significa a análise da água, pois ao isolar os elementos perdem-se as propriedades que só podem ser observadas em conjunto. Assim, o autor propõe a análise a partir de unidades em vez de elementos, entendendo como unidade aquilo que contém as propriedades fundamentais do conjunto. Dessa forma, na análise da relação entre pensamento e fala, Vigotski estudou como unidade o significado das palavras, pois este é um fenômeno tanto do pensamento - devido à generalização - tanto da fala - já que a palavra sem significado torna-se apenas um som vazio.

Analisando a relação entre pensamento e fala a partir dos significados da palavra, Vigotski (2012) desenvolve os conceitos de significação e sentido, que integram as dimensões intelectual e afetiva na formação da psique. $\mathrm{O}$ autor faz uma distinção entre esses conceitos, destacando que:

el sentido de la palabra representa la suma de todos os hechos psicológicos surgidos en la consciência a causa de la palabra. Por lo tanto, el sentido de la palavra resulta siempre uma formación dinâmica, fluida y compleja, que posee varias zonas de desigual estabilidade. El significado es solo una de las zonas del sentido que adquiere la palavra en el contexto de determinado discurso y, además, la zona más estable, unificada y precisa. (VIGOTSKI, 2012, p. 493)

Entendido dessa maneira, o sentido da palavra entrelaça os conteúdos intelectuais e afetivos, podendo mudar nas distintas consciências e na mesma consciência individual em distintas circunstâncias. O sentido representa, portanto, um aspecto psicológico da palavra, onde há uma relação inseparável entre palavra e consciência. Nesta perspectiva, o sentido é mais amplo que o significado e apresenta dinamicidade e fluidez. Vigotski salienta ainda que para compreender a fala de uma pessoa não basta apenas entender o significado das palavras que estão sendo ditas e o contexto, é necessário compreender o caminho do pensamento até as palavras e as motivações da pessoa.

El propio pensamiento no surge de outro pensamiento, sino de la esfera motivacional de nuestra conciencia, que compreende nuestras inclinaciones y necesidades, nuestros intereses y impulsos, nuestros afectos y emociones. Tras el pensamiento se halla la tendencia afectiva y volitiva. (VIGOTSKI, 2012, p. 508) 
Assim, as origens da fala e pensamento não tem origem apenas na dimensão intelectual, pois o indivíduo fala e pensa a partir de seus desejos, sentimentos, intenções e motivações e, neste processo, dá sentido às palavras e às situações que vivencia.

Os afetos têm, portanto, papel constitutivo na vida psíquica. Ao desenvolver a categoria sentido, Vigotski $(1998,2012)$ tenta representar a psique de maneira sistêmica, integrada, em constante desenvolvimento, rompendo com a fragmentação dominante na psicologia de sua época. Apesar desse avanço, o autor não teve tempo de desenvolver a categoria de maneira aprofundada. Contudo, sua abordagem abriu novas possibilidades de interpretação dos processos psicológicos dando visibilidade a aspectos que antes eram desconsiderados.

Dentro dessas perspectivas, González Rey (2003) tem desenvolvido a categoria de sentido subjetivo, articulando a dimensão de sentido a uma nova representação da subjetividade, entendida como forma complexa de organização da psique. O sentido subjetivo permite o registro subjetivo das diferentes experiências sociais do sujeito, que passam a fazer parte da organização subjetiva da pessoa a partir da unidade das dimensões simbólico-emocionais. Esta categoria será apresentada no próximo capítulo, dedicado à Teoria da Subjetividade.

Pensando nas contribuições da perspectiva histórico-cultural para a compreensão do contexto escolar, entendemos que o conceito de zona de desenvolvimento iminente permite articular a dimensão social aos processos de aprendizagem e desenvolvimento, entretanto Mitjáns Martinez (2006) destaca que o outro mais experiente participa do processo de aprendizagem não apenas pelas ações que realiza, mas pelo espaço comunicativo-emocional que contribui para que o sujeito que aprende produza sentidos sobre essas ações. Neste entendimento, não é a função instrumental do outro que tem relevância, mas a relação emocional da criança com outra pessoa, dentro de um processo de comunicação que irá atuar como fonte de desenvolvimento.

Para Tunes, Tacca e Bartholo (2005), o adequado entendimento do conceito de zona de desenvolvimento proximal ou iminente requer considerar que educar é nutrir possibilidades relacionais.

Ajudar é possibilitar o fazer com; é dialogar, portanto. Se o ajudante for o professor, a ajuda é planejada e sistemática, pois seu impacto no aluno é esperado como realização. Logo, é preciso conhecer o que já há; novamente, o diálogo. Conhecer o que há para definir o que poderá ser. Nesse jogo assimétrico, professor e aluno feremse, atingem-se mutuamente. $\mathrm{O}$ aluno dirige o seu próprio processo de aprender, restringindo, ativamente, as possibilidades de ação do professor. Por seu turno, o professor é quem planeja e cria as condições de possibilidade de emergência das potencialidades do aluno (TUNES; TACCA; BARTHOLO, 2005, p. 694) 
Não se trata apenas de criar ações instrumentais de ajuda para os processos que as crianças ainda não dominam de maneira independente, mas de criar estratégias para que professor e alunos estejam por inteiro na relação pedagógica, onde o diálogo seja um importante recurso para conhecer as necessidades e especificidades do outro.

Andrada (2006) destaca, baseada nos estudos de Vigotski, que há que se avançar na consideração do professor como mediador das práticas pedagógicas para a compreensão do professor como organizador do ambiente social, onde ele estabelece as condições para possibilidade dos processos de aprendizagem e desenvolvimento, tendo por base as relações dialógicas construídas na sala de aula. Para a autora, as interpretações da obra de Vigotski no meio educacional que conduzem à ideia do professor como agente mediador, como aquele que faz a interposição entre aluno e conhecimento, incorrem no erro de considerar o professor como mera ferramenta de ensino e colocar a primazia da ação docente na transmissão dos conteúdos em vez do desenvolvimento do aluno. Sendo assim, a interpretação mais adequada da relação com o outro na psicologia histórico-cultural coloca a relevância não mais na mediação, mas na relação pedagógica, onde a partir do encontro e do diálogo o professor tem possibilidades de conhecer os processos de aprendizagem de seus alunos para, assim, buscar organizar o trabalho pedagógico. (TACCA, 2004)

Concordamos com a autora que essas relações não estão estabelecidas a priori, mas precisam ser construídas a partir do envolvimento e do vínculo com o outro. Neste sentido, entendemos que os processos relacionais implicam a constituição subjetiva do sujeito, entendido não apenas em sua dimensão intelectual, mas como sistema complexo.

Ao introduzir os conceitos de situação social de desenvolvimento, vivência e sentido, apesar de não ter tido tempo de elaborar um sistema teórico com categorias bem definidas, Vigotski deixa um sistema de opções a serem desenvolvidas como desdobramentos de sua obra. González Rey desenvolve uma nova representação da psique como sistema que integra o simbólico e o emocional de maneira complexa, a partir da Teoria da Subjetividade numa perspectiva cultural-histórica, que será apresentada no próximo capítulo para avançar as discussões iniciadas. 


\section{A TEORIA DA SUBJETIVIDADE NUMA PERSPECTIVA CULTURAL- HISTÓRICA, DE GONZÁLEZ REY}

Compreendendo a psique humana como sistema complexo a partir da integração única de diferentes processos e formações psicológicas em cada sujeito concreto, González Rey (2002, 2003, 2005) tem desenvolvido a Teoria da Subjetividade numa perspectiva culturalhistórica. Ao criticar as tendências da psicologia que tratam o tema da subjetividade a partir do mentalismo, racionalismo ou subjetivismo, em que os processos psicológicos são vistos ora de maneira fragmentada ora como reação a estímulos, o autor se apoia nas contribuições da psicologia histórico-cultural, em que o conceito de mente é inseparável da cultura, para desenvolver uma compreensão da psique como sistema.

O tema da subjetividade foi negado por diversas perspectivas teóricas desenvolvidas no século XIX, onde o subjetivo era associado ao oculto, ao interno ou como reflexo do externo. Por um lado, havia uma visão naturalista e, consequentemente, individualista dos processos humanos complexos analisados de maneira independente das produções de sentido dos espaços sociais. Em contrapartida, as tendências que criticavam o naturalismo e atribuíam maior ênfase aos fenômenos sociais incorriam no equívoco de analisar a produção dos sujeitos como reflexo objetivo das condições de vida, ignorando o caráter singular das ações individuais.

Buscando romper com essas dicotomias entre individual e social, interno e externo, cognitivo e afetivo, González Rey (2002, 2003, 2005) preocupa-se em desenvolver uma definição ontológica da subjetividade. A compreensão da subjetividade como sistema complexo considera sua organização de maneira plurideterminada, multidimensional e sistêmica, onde aspectos dos fenômenos sociais e psicológicos se integram e inter-relacionam numa tensão constante. Nesta perspectiva, a subjetividade não é entendida apenas como uma organização interna ou intrapsíquica, mas como constitutiva do indivíduo e das diferentes formas de organização social. (GONZÁLEZ REY, 2005)

Nesta perspectiva, a psique humana deve ser entendida a partir do caráter subjetivo dos processos individuais e sociais que são inseparáveis da cultura. A subjetividade é, portanto, constituída na cultura e vista não apenas como uma produção objetiva da vida social ou expressão direta das condições concretas, mas como

uma produção subjetiva que expressa as condições de vida do homem em cada momento histórico e em cada sociedade concreta, mas que constitui uma produção diferenciada que indica precisamente o curso dos processos de subjetivação que orientam a ação humana em cada época e ambiente em que essa ação foi realizada. (GONZÁLEZ REY, 2012b, p. 124) 
Dessa forma, os espaços sociais e culturais não determinam de maneira linear a subjetividade, pois ela também é subjetiva. As formas objetivas da vida social adquirem dimensão subjetiva através dos sistemas de sentido e significação dos diferentes grupos sociais, onde a partir das relações nesses grupos se constitui a subjetividade individual e social. Assim, o desenvolvimento do homem em sua dimensão subjetiva e a cultura se constituem simultânea e reciprocamente.

A teoria da subjetividade numa perspectiva cultural-histórica permite compreender a psique individual como constituída pelos espaços sociais, ao mesmo tempo em que é constituinte desses espaços pela multiplicidade de produções dos sujeitos. Assim, a subjetividade está constituída tanto no sujeito individual - subjetividade individual - como nos diferentes espaços sociais - subjetividade social. A subjetividade social representa a organização de um sistema de configurações subjetivas dos diferentes espaços da sociedade, que é constituído pelas crenças, mitos, valores, representações, moralidade, etc e através da produção de sentidos que ocorrem nos espaços e grupos em que os sujeitos participam. (GONZÁLEZ REY, 2005)

A partir das relações e interações nas diversas instituições que caracterizam a vida humana em determinada cultura, o indivíduo vai se constituindo integrando-se à subjetividade social, não de maneira linear e direta, mas em um processo diferenciado e singular, de acordo com suas especificidades individuais e com os modos que adquirem as relações entre o individual e o social. Ao atuar e interagir nesses espaços sociais, as ações dos sujeitos também vão constituindo estes espaços, adquirindo sentidos subjetivos diversos para os outros integrantes, gerando momentos de subjetivação que podem se configurar no desenvolvimento da subjetividade social daquele contexto. (GONZÁLEZ REY, 2003)

Dessa maneira, esses dois níveis - subjetividade social e subjetividade individual - não são independentes, estão constantemente inter-relacionados, onde os espaços sociais geram formas de subjetivação a partir da complexa relação entre individual e social. Nas palavras de González Rey (2005, p. 25):

O sujeito individual está inserido, de forma constante, em espaços de subjetividade
social, e sua condição de sujeito atualiza-se permanentemente na tensão produzida a
partir das contradições entre suas configurações subjetivas individuais e os sentidos
subjetivos produzidos em seu trânsito pelas atividades compartilhadas nos diferentes
espaços sociais.

Dessa maneira, a subjetividade social e a subjetividade individual fazem parte de um mesmo sistema e a partir das tensões e contradições entre esses níveis, as produções de sentidos 
subjetivos participam do desenvolvimento dos sujeitos e dos espaços sociais em que eles atuam, gerando momentos de ruptura e continuidade, contradição e coerências.

Na subjetividade social de um espaço concreto também se integram configurações de sentido provenientes de outros contextos, já que o sujeito participa de vários espaços sociais que estão constantemente relacionados entre si. Se considerarmos a subjetividade social da escola, por exemplo, esta é constituída não só pelos sentidos subjetivos produzidos no interior do espaço escolar - como a sala de aula, a coordenação pedagógica, as festas e eventos, as formas como se organiza e se efetiva o projeto político pedagógico, a relação entre os funcionários, a relação entre os professores e alunos, a participação dos pais e da comunidade, o posicionamento da equipe gestora, dentre tantos outros aspectos - mas também de elementos de sentidos relacionados à posição sócio-econômica, de costumes e crenças das famílias, de religiosidade, dentre outros vividos fora da escola. Todos esses elementos de diferentes procedências se integram na configuração da subjetividade social que, por sua vez, constitui de maneira recursiva a subjetividade individual dos sujeitos que frequentam aquela escola.

Essa relação complexa afasta a compreensão da subjetividade como algo próprio de abstração, intrínseco ao indivíduo, e pressupõe a compreensão, tanto dos indivíduos quanto da sociedade em termos de desenvolvimento.

\footnotetext{
As ações dos sujeitos implicados em um espaço social compartilha elementos de sentido e significados gerados dentro desses espaços, os quais passam a ser elementos de subjetividade individual. Entretanto, essa subjetividade individual está constituída em um sujeito ativo, cuja trajetória diferenciada é geradora de sentidos e significações que levam ao desenvolvimento de novas configurações subjetivas individuais que se convertem em elementos de sentidos contraditórios com o status quo dominante nos espaços sociais que o sujeito atua. Essa condição de integração e ruptura, de constituído e constituinte que caracteriza a relação entre o sujeito individual e a subjetividade social, é um dos processos característicos do desenvolvimento humano. (GONZÁLEZ REY, 2003, p. 207)
}

A subjetividade pode ser entendida como a organização dos processos psicológicos em um sistema complexo que integra as emoções do sujeito, o pensamento, as situações vividas por ele, por meio da produção de sentidos subjetivos que ocorre em todos os processos e formas de organização da atividade humana. Para explicar essa produção de sistemas de sentidos, González Rey (2003, 2006, 2012) desenvolveu a categoria de sentidos subjetivos, entendidos como a unidade dos processos simbólicos e emocionais que aparecem e se organizam de diferentes formas nos sujeitos. Ao desenvolver essa categoria, González Rey avança ao compreender que o sentido é uma unidade em sua relação inseparável com a subjetividade, entendendo os sentidos subjetivos como: 
expressões de uma teia simbólico-emocional na qual as emoções, sentidos e processos simbólicos de procedência muito diferentes integram-se na definição das diversas configurações subjetivas que acompanham os diferentes tipos de atividades humanas. (GONZÁLEZ REY, 2006, p. 35)

Nesta conceituação, o autor vai além daquilo que Vigotski havia desenvolvido como significado e sentido da palavra. Além disso, González Rey não considera apenas a influência da dimensão afetiva e interpretativa frente à palavra, mas o papel constitutivo das emoções em sua unidade inseparável com os processos simbólicos que surgem e se organizam em cada experiência do sujeito e tem relação não só com a própria experiência concreta, mas com outros momentos vividos em outros espaços sociais e com a própria história de vida do sujeito. Entendidos dessa maneira, os sentidos subjetivos não representam apenas uma interpretação ou uma absorção linear da realidade, mas uma produção, onde todas as experiências vividas no plano social se integram em desdobramentos simbólico-emocionais nas diversas configurações subjetivas.

Nesta definição, o sentido subjetivo passa a se relacionar a todos os espaços simbolicamente produzidos pela e na cultura, que se integram a emocionalidades de origens diversas. As emoções podem evocar processos simbólicos, assim como os processos simbólicos associados a um sentido subjetivo podem provocar emoções, sem que um seja a causa do outro e sem que um se reduza ao outro (GONZÁLEZ REY, 2005). Os sentidos subjetivos representam a integração permanente dos processos simbólicos e emocionais formando uma complexa unidade. Assim, uma mesma situação objetiva concreta, como, por exemplo, a realização de uma atividade escrita na sala de aula, pode ter significado convergente para alunos diferentes, mas tendo o valor emocional distinto. Isso influirá na produção de sentidos subjetivos, que terá relação não apenas com a atividade concreta em si, mas com a trajetória de vida desses alunos, suas experiências em outros espaços sociais, o valor que eles atribuem à aprendizagem e à atividade realizada, à relação com o conhecimento e com o professor em questão, às experiências anteriores de fracasso ou êxito em outras atividades (escolares ou não), processos estes que muitas vezes estão além da capacidade de conscientização do sujeito.

Dessa forma, não há características universais da subjetividade, assim como não há sentidos subjetivos universais, pois todo sentido subjetivo se produz no singular, em relação com a história de vida do sujeito, que não é vista como a soma dos acontecimentos objetivos da vida da pessoa, mas como a configuração subjetiva singular das suas experiências nos espaços sociais que transita. Esses sentidos subjetivos passam a formar parte da organização subjetiva da pessoa, mas não como algo fixo e estático, pois estão em constante desenvolvimento. Nas palavras de González Rey (2011, p.33): 
um sentido subjetivo é uma unidade simbólico-emocional que é produzida num momento atual, mas que não pode ser compreendida em uma unidade isolada em si mesma. Essa unidade, por sua vez, se transforma rapidamente, plasticamente, gerando cadeias de sentidos subjetivos que só se tornam inteligíveis no momento de interpretação da configuração subjetiva, que é o que permite captar os sentidos subjetivos dominantes, presentes na expressão plural da pessoa que aparece, de forma simultânea, em cada momento da ação concreta.

O autor $(2002,2005,2011)$ tem utilizado a categoria configuração subjetiva para se distanciar de conteúdos universais e estáticos, se referindo a um núcleo de organização de sentidos subjetivos, que se apresenta de maneira mais estável, sem, no entanto, perder a dinamicidade por estar dentro de um sistema configuracional. As configurações subjetivas representam redes de sentidos subjetivos que se integram na organização da subjetividade, onde os processos históricos e atuais e as diversas experiências vivenciadas aparecem subjetivadas em configurações, que não devem ser entendidas como a soma de diversos sentidos subjetivos, pois a própria integração destes representa novos momentos de subjetivação. Os sentidos subjetivos aparecem em todas as atividades humanas e as configurações subjetivas representam a unidade dos sentidos subjetivos predominantes, de maneira relativamente estável, integrando a multiplicidade dos espaços sociais e dos processos históricos no momento atual da atividade. Apesar dessa relativa estabilidade, as configurações subjetivas não deixam de ser fluidas, podendo haver mudanças nos sentidos subjetivos que a constituem, que podem levar a reorganização no núcleo da configuração e promover mudanças no desenvolvimento da personalidade do sujeito.

As configurações subjetivas compõem a subjetividade individual, que representa os processos e formas de organização da subjetividade do individuo. Assim, processualidade e organização estão em constante relação na compreensão da subjetividade humana. Essa compreensão sistêmica e complexa da subjetividade orienta a uma forma diferente de entender a personalidade. González Rey (2003) faz criticas à maneira como as tendências dominantes na psicologia tem compreendido a personalidade que, dentro de um modelo empírico tem sido entendida como conjunto de traços universais que representam as causas de determinados comportamentos. Nessa compreensão, o ser humano é visto de maneira fragmentada e estática, além de se desconsiderar as especificidades dos aspectos culturais e sociais e das trajetórias individuais singulares de cada pessoa. Para o autor, a personalidade apresenta-se como organização sistêmica da subjetividade individual.

A personalidade deixa de ser compreendida como causa que atua de fora da ação do sujeito para passar a ser um momento de sentido da própria ação. Dessa forma, a personalidade adquire uma plasticidade que não foi considerada dentro de nenhum dos marcos anteriores que já trabalharam. Na personalidade aparecem organizados 
subjetivamente todas as experiências do sujeito em um sistema em que os sentidos subjetivos produzidos por uma experiência passam a ser elementos constituintes de outras, dando lugar a cadeias complexas de configurações que aparecem no sentido subjetivo produzido a cada experiência concreta do sujeito. (GONZÁLEZ REY, 2003, p. 256)

A partir dessa compreensão da personalidade numa perspectiva cultural-histórica destacam-se os seguintes aspectos: a plasticidade e a capacidade geradora. A partir da dinamicidade das configurações subjetivas, o sujeito tem possibilidade de mobilidade nas experiências sociais. Assim, ao vivenciar experiências que se tornam impactantes devido aos sentidos subjetivos produzidos naquele momento, este processo pode representar novos espaços de subjetivação, refletindo na reorganização das configurações subjetivas da pessoa e de sua personalidade, gerando o desenvolvimento pessoal. Esse processo não acontece de maneira direta e linear, mas a possibilidade de mudanças, dentro do sistema da subjetividade, recupera o lugar do sujeito em seu próprio desenvolvimento. Dessa forma, os indivíduos não devem ser compreendidos a partir de características universais e fixas, que estão dadas de fora, mas sim a partir de suas produções singulares no curso diferenciado de suas vidas.

Todo esse processo ocorre em constante relação entre o social e o individual que representam uma das contradições do desenvolvimento humano, pois ao mesmo tempo em que a personalidade é constituída pela subjetivação de aspectos da subjetividade social, é justamente através dos recursos singulares da personalidade que o sujeito tem opções para produzir espaços subjetivos alternativos àqueles que o constituem, gerando novos processos de subjetivação dentro de seu próprio sistema organizador podendo, inclusive, influenciar na constituição da subjetividade social nos espaços em que participa.

Essa relação dialética entre social e individual e o caráter gerador da subjetividade permitem recuperar a ideia de sujeito, compreendendo o homem em seu caráter dialético e complexo, onde a relação com o social não é determinante, mas plurideterminada a partir das produções de sentidos subjetivos. Neste processo, o sujeito não é passivo, é constituído subjetivamente em sua própria história e suas ações são fonte de subjetivação. O termo sujeito não deve ser entendido como um adjetivo, mas como uma categoria da teoria, que representa a capacidade ativa e participativa dos indivíduos. O sujeito é interativo, sujeito do pensamento, da linguagem, da emoção, onde produz opções que não são apenas cognitivas, mas caminhos de sentidos subjetivos que influenciam seus processos psicológicos e suas práticas sociais. (GONZÁLEZ REY, 2003)

Nem sempre a posição de sujeito foi reconhecida nas perspectivas teóricas desenvolvidas, o que se reflete ainda na atualidade nos mais diversos cenários sociais. Por vezes 
o indivíduo é visto como subordinado às características sociais ou a-sujeitado ao desenvolvimento da linguagem, concepções que desconsideram as formas alternativas e opções singulares que o sujeito pode desenvolver nos espaços que atua. Através da ação singular do sujeito, ele representa uma opção de mudança que pode gerar novos processos de subjetivação.

\subsection{Contribuições para a compreensão da educação e dos processos relacionais na sala de aula}

A inter-relação das categorias analisadas permite compreender a subjetividade humana em diversos contextos sociais, dentre eles a escola. Historicamente, o espaço escolar tem sido organizado muito mais como local de transmissão do conhecimento acumulado pela sociedade que como espaço de desenvolvimento e produção de conhecimento. A tendência à hierarquização e padronização na organização da escola e a compreensão da aprendizagem como função exclusivamente cognitiva e intelectual desconsidera os aspectos subjetivos envolvidos no desenvolvimento humano, por vezes dificultando o percurso escolar de muitas crianças.

Apesar de constantes discussões sobre os problemas da educação escolar na contemporaneidade, a organização do trabalho pedagógico ainda ocorre a partir de modelos, pelos quais se espera que todas as crianças aprendam as mesmas coisas, da mesma forma, no mesmo período de tempo. Essa expectativa pode estar baseada numa compreensão reducionista de desenvolvimento e aprendizagem, onde o sujeito é reduzido às funções cognitivas e intelectuais, que parecem ser as únicas valorizadas pela educação escolar. Tal perspectiva se coaduna com a representação fragmentada da psique, em que a complexidade constitutiva do indivíduo é desconsiderada, e o mesmo é visto a partir de elementos isolados, evidenciando dicotomias entre cognitivo e afetivo, individual e social.

A compreensão da teoria da subjetividade numa perspectiva cultural-histórica traz a possibilidade de revisão das práticas institucionais a partir de um novo sistema teórico que permite romper com a fragmentação na consideração nos processos de desenvolvimento humano. Nesta perspectiva, o objetivo da educação não deve se resumir à transmissão de um saber para o aluno, mas principalmente o de promover seu desenvolvimento como sujeito, o que implica a sua participação ativa. Este processo só será possível se a atividade educacional implicar o aluno subjetivamente, através da produção de sentidos subjetivos que envolvem não 
apenas dimensões intelectuais, mas todo um sistema composto por dimensões afetivas, relacionais, dialógicas, entre outras mais.

Não se trata de desconsiderar a dimensão cognitiva, mas de vislumbrar que esta não é a única, tampouco a mais importante na constituição do sujeito aprendiz. É certo que é função da escola promover o desenvolvimento do pensamento e da linguagem, contudo buscar esse desenvolvimento a partir de situações unicamente operacionais, situadas fora do sujeito não tem se mostrado eficaz. Trata-se de considerar a expressão da linguagem e do pensamento a partir da constituição subjetiva de quem fala e pensa. De acordo com González Rey:

\footnotetext{
O pensamento se define como um processo psicológico, não somente por seu caráter cognitivo, mas por seu sentido subjetivo, pelas significações e emoções que se articulam em sua expressão, que não é automática, mas construída pelo sujeito mediante complexos desenhos intencionais e conscientes, nos quais também não se esgota seu caráter subjetivo. (GONZÁLEZ REY, 2003, p. 235)
}

O pensamento deve ser entendido, portanto, também como um processo de sentido subjetivo, a partir de situações e conteúdos que implicam o sujeito através das produções que irão configurar processualmente sua subjetividade individual. Dessa mesma forma, a linguagem também não pode ser reduzida apenas aos aspectos simbólicos ou tratada como reflexo da participação social dos indivíduos. E ela aparece como momento de um processo de subjetivação, onde se converte em novos momentos constituintes da configuração do sujeito. Essa compreensão recupera o valor do sujeito na medida em que destaca a sua capacidade geradora, para além da expressão reprodutiva.

Em seus estudos sobre a relação entre pensamento e linguagem, Vigotski (2012, p.508) ao elaborar a categoria sentido já considerava a importância da afetividade nesse processo, ao postular que "tras el pensamiento se halla la tendencia afectiva y volitiva" e, ainda, "solo es posible comprender efectiva y cabalmente el pensamiento ajeno cuando descubrimos su transfondo afectivo-volitivo real."

Nesta compreensão, o autor tentava integrar as dimensões afetiva e cognitiva em uma mesma unidade. Posteriormente, González Rey (2002, 2003, 2005) desenvolve a categoria de sentido subjetivo a partir de uma nova representação da subjetividade, onde as emoções têm papel fundamental. As emoções que estão relacionadas às ações dos sujeitos nos espaços sociais e nos processos interativos que eles participam influenciam a forma desses sujeitos se mobilizarem para o desenvolvimento de determinada atividade, processo que não se dá de maneira linear, mas a partir da produção de sentidos subjetivos sobre a experiência. Nas palavras do autor: 
[...] é a emoção que define a disponibilidade dos recursos subjetivos do sujeito para atuar, o que é, em si mesmo, um sentido subjetivo que aparece por meio de emoções que expressam a síntese complexa de um conjunto de estados sobre os quais o sujeito tem ou não consciência, mas que são essencialmente estados afetivos, que historicamente têm se definido por categorias como autoestima, segurança, interesse, etc, que são estados que definem o tipo de emoção que caracteriza o sujeito para o desenvolvimento de uma atividade e dos quais vai depender muito a qualidade da realização do sujeito nessa atividade. (GONZÁLEZ REY, 2003, p. 245)

Tomando-se como referência o contexto da escola e, mais especificamente, da sala de aula pode-se considerar que o envolvimento do aluno em determinada atividade dependerá em grande parte das emoções geradas por ela, emoções essas que serão configuradas subjetivamente em unidade com os aspectos simbólicos, produzindo diferentes sentidos subjetivos. Como já citado anteriormente, historicamente, a dimensão da emoção na aprendizagem tem sido tratada a partir de categorias como motivação, autoestima, necessidades, dentre outros, muitas vezes analisados como elementos em separado a partir de uma visão intrapsíquica. A consideração desses aspectos a partir da produção de sentidos subjetivos requer a compreensão da dimensão relacional dos processos interativos, onde o envolvimento do aluno em determinada situação não deve ser visto a partir das características intrínsecas a ele, mas aos processos de subjetivação que ocorrem continuamente na relação com o outro, seja o professor ou os colegas. Além disso, conceber o desenvolvimento do aluno a partir de sua constituição subjetiva permite a compreensão do funcionamento integral e sistêmico do sujeito.

Dessa forma, a aprendizagem escolar deve, portanto, ser concebida como processo da subjetividade. Mitjáns Martinez (2006) apresenta três razões para fundamentar essa afirmação. A primeira é o reconhecimento das configurações de sentido que participam do processo de aprender. O sujeito aprende não apenas como intelecto, mas como sistema complexo, no qual se articulam dimensões cognitivas, afetivas, relacionais, personológicas, etc, emergindo por meio da produção de sentidos subjetivos. Os processos simbólicos e emocionais que surgem no momento de aprender não necessariamente têm relação direta com a situação concreta específica, mas podem ser processos de sentido oriundos de outras experiências e história de vida que podem se constituir como elementos subjetivos da aprendizagem. As operações intelectuais podem ser bloqueadas, por exemplo, se o aluno vivenciar o fracasso subjetivamente antes mesmo da realização da tarefa.

A segunda razão é a consideração da aprendizagem escolar como função do sujeito, o que pressupõe sua ação intencional, ativa, interativa e emocional. González Rey (2006) tem elaborado a ideia de "sujeito que aprende" para destacar o caráter singular do processo de 
aprender, onde o aluno se posiciona a partir de suas experiências e formas diferenciadas de lidar com as situações no espaço escolar. Considerar a aprendizagem como função do sujeito requer a construção de práticas pedagógicas que permitam o posicionamento ativo e reflexivo dos alunos, o que só será possível a partir de práticas dialógicas. Para o autor (2006, p. 39) "as emoções que permitem a emergência de sentidos subjetivos só aparecerão com o compromisso pessoal, com o interesse em se posicionar ante o aprendido e defender e avançar por meio de posições próprias".

Esse posicionamento coloca para a escola o desafio de repensar práticas padronizadas que hegemonicamente tem caracterizado a organização do trabalho pedagógico e criar estratégias para a efetivação de um cenário social participativo na sala de aula que impliquem os alunos em seus processos subjetivos.

Finalmente, a terceira razão para justificar a aprendizagem como processo da subjetividade é o reconhecimento de que na aprendizagem escolar se expressam a subjetividade individual e a subjetividade social. A subjetividade social da escola é composta, dentre outros aspectos, pela rede de significados construídos culturalmente sobre como se processa a aprendizagem escolar. Por sua vez, esses significados são apropriados e reconstruídos individualmente a partir dos sistemas relacionais entre os sujeitos e contribuem para a formação dos sentidos subjetivos singulares. Assim, no espaço da sala de aula, as subjetividades individual e social estão inter-relacionadas nas dinâmicas que ocorrem durante o processo de aprendizagem. (MITJÁNS MARTINEZ, 2006)

Compreender a aprendizagem escolar como processo da subjetividade significa considerar a aprendizagem como processo relacional, onde o outro constitui parte importante do processo de aprender, não como ações instrumentais e operacionais, mas como parte constitutiva do processo. Recuperando a compreensão sobre zona de desenvolvimento proximal elaborado por Vigotski (2002) e traduzido por Prestes (2010) como zona de desenvolvimento iminente percebe-se que a apropriação desse conceito na educação foi e ainda tem sido feita com caráter operacional, onde o outro (professor ou colega mais experiente) é visto apenas a partir de suas ações e não nos processos de sentido subjetivo que essas ações e pessoas podem gerar. Não se pode negar que o conceito de zona de desenvolvimento iminente apresenta muitas contribuições para a educação por considerar a dimensão social da aprendizagem: a dimensão prospectiva da aprendizagem que, se efetivada, gera desenvolvimento e a importância da mediação pedagógica. Entretanto, seria reducionista considerar esse aspecto apenas por seu caráter instrumental. As possibilidades de desenvolvimento não dependem só da mediação dos 
recursos culturais, mas dos recursos subjetivos que compõem a configuração subjetiva das funções psíquicas.

O fato de recuperar o lugar do aluno como sujeito não significa que a responsabilidade da aprendizagem seja só dele ou só no professor a partir da elaboração de práticas pedagógicas participativas, mas simultaneamente acontece na relação pedagógica. A importância do papel do outro no processo de aprendizagem se dá pela construção de um espaço comunicativoemocional que pode contribuir para a geração de sentidos subjetivos no sujeito que aprende.

Ao professor caberá a tarefa constante de considerar as singularidades na coletividade da sala de aula, entendendo esse espaço como contexto gerador de subjetividade social onde sujeitos singulares se relacionam entre si e com o conhecimento a partir de suas subjetividades individuais, inclusive a do próprio professor, ao mesmo tempo em que constituem aquele espaço e são por ele constituídos. O desafio está na busca permanente por compreender os modos singulares de aprender dos alunos e a dinâmica que se estabelece naquele espaço social perante a aprendizagem para, com isso, direcionar o trabalho pedagógico às necessidades e especificidades dos sujeitos que aprendem. (MADEIRA-COELHO, 2009)

Para delinear estratégias pedagógicas é necessário que o professor conheça o nível de desenvolvimento já atingido pelo aluno, os conhecimentos, habilidades que possui, as formas como ele se relaciona com o conhecimento, como são seus processos de pensamento, quais as dificuldades que encontra e as necessidades específicas. Para além desses aspectos mais operacionais é fundamental também conhecer aspectos da configuração subjetiva das crianças que podem estar relacionadas ao processo de aprender. Os interesses, gostos, sentidos que tem para o aluno a escola, o processo de aprendizagem, o espaço da sala de aula, as emoções que vivencia, etc, precisam ser do conhecimento do professor.

\footnotetext{
Especial relevância tem o conhecimento da história de vida da criança, seus principais contextos de desenvolvimento, os principais sistemas interativos em que está inserido, as pessoas com as quais estabelece um vínculo afetivo real e as principais influências educativas. Isso, junto ao conhecimento de seus aspectos positivos, suas forças e possibilidades permitirão, não apenas compreender muitos aspectos de seu processo de aprendizagem, mas também delinear estratégias pedagógicas que o considerem de forma sistêmica. (MIJÁNS MARTINEZ, 2006, p. 384)
}

O professor, também considerado como sujeito da sua ação profissional, deve orientarse por objetivos próximos às crianças, relacionados às suas singularidades. A singularidade não deve ser tratada como sinônimo de individualidade, pois representa um momento qualitativo da subjetividade, se constituindo como realidade diferenciada na história da constituição subjetiva do indivíduo (GONZÁLEZ REY, 2002). Trabalhar com o aluno a partir de sua singularidade, 
significa considerar sua forma única e diferenciada de constituição subjetiva. Assim, não existem modelos universais de alunos, professores ou práticas pedagógicas, pois a manifestação dos sujeitos concretos na sala de aula estará relacionada aos processos de sentido produzidos naquele espaço e ao curso diferenciado de suas trajetórias de vida.

Neste sentido, estamos compreendendo as estratégias pedagógicas na perspectiva de Tacca (2006a, p. 48) que entende que essas estratégias seriam "recursos relacionais que orientam o professor na criação de canais dialógicos", permitindo compreender o pensamento e emoções do aluno para a elaboração de novas possibilidades de atuação. A criação desses recursos relacionais que permitam captar o outro exige a disponibilidade constante dos sujeitos da relação.

Estar junto em um mesmo espaço físico num mesmo período de tempo não necessariamente garante que os sujeitos estejam em relação. Construir um espaço relacional na sala de aula requer que professores e alunos se voltem um para o outro em um encontro dialógico.

Tunes e Bartholo (2004) defendem que a atitude de voltar-se um para o outro na criação de um espaço inter-humano implica a alteridade e requer uma disposição ao diálogo. Os autores destacam que para entrar em diálogo é necessária uma atitude de reciprocidade e compromisso, onde um se disponibiliza para o outro, o que permite o encontro entre as pessoas.

Para Tacca (2004, 2006b), o professor como organizador do ambiente social da sala de aula deve estar inclinado a ir ao encontro dos alunos, buscando ter um conhecimento íntimo dos mesmos, pois os modos de intervenção serão mais produtivos se estiverem relacionados a percepção da singularidade do outro.

\footnotetext{
Ensinar, nesta proposição, significa mais do que se preocupar com estratégias e métodos de ensino em si, mas implica, sobretudo, reconhecer a importância de conhecer o fio da história constitutiva da configuração subjetiva dos sujeitos da aprendizagem, procurando compreender a forma como se imbricam nela o afeto e a cognição. O desafio torna-se, então, encontrar canais que permitam fluir e convergir os processos de significação na direção dos objetivos educacionais. (TACCA, 2006b, p. 61)
}

A comunicação, considerada como a utilização plena do diálogo, apresenta-se como importante canal que permite o encontro na relação. O aluno tratado de maneira coletivizada, onde a turma recebe orientações amplas e gerais do professor, dificulta a aproximação e o envolvimento necessário à criação de um espaço relacional na sala de aula. A despeito das dificuldades relativas ao quantitativo de alunos na sala de aula, pode-se inferir que muitos professores não buscam tal aproximação por não perceberem a importância das situações 
comunicativas como momentos que podem promover o desenvolvimento. Segundo González Rey (1999, p. 26),

la comunicación implica el reto de la diferenciación, de la individualización, de crear espacios diferenciados com los alunos actuando flexiblemente en la expresión de nuestra propia representación. La comunicación se construye entre dos sujetos que encuentran um espacio interactivo común y específico; es imposible llevarla a formas únicas sobre el rol y la función de cada parte en interacción.

A comunicação aparece, portanto, como via privilegiada para a consideração da sala de aula como espaço relacional e a aproximação com os processos de sentido produzidos neste contexto. Conhecer os alunos para além dos aspectos instrumentais supõe a aproximação com os mesmos no sentido de construir espaços relacionais e dialógicos no contexto da sala de aula.

Campos (2005) argumenta que a comunicação deve ser personalizada, a partir da busca da individualização da relação, onde o aluno sendo valorizado e respeitado pelo professor em sua singularidade poderá sentir mais confiança para expressar as questões necessárias ao fortalecimento da relação. Em pesquisa sobre a constituição subjetiva de alunos em situação de fracasso escolar, a autora destacou que a relação personalizada estabelecida foi elemento de sentido subjetivo para um dos alunos investigados, onde a partir dessa relação, que foi considerada unidade subjetiva de desenvolvimento, houve a possibilidade de desenvolvimento pessoal, social e pedagógico do aluno.

Sobre o tema da confiança consideramos relevantes as ponderações de Mc Dermott (1977) sobre as "relações de confiança" entre professores e alunos. O autor destaca que a confiança não é um atributo da personalidade, mas um produto do envolvimento entre pessoas no sentido de construir um contexto de negociações e se responsabilizarem mutuamente pelo alcance de determinado objetivo. A eficácia da prática pedagógica depende, portanto, das relações sociais estabelecidas com as diferentes crianças no contexto da sala de aula e isso implica o direcionamento da atenção do professor às necessidades individuais da criança e a criação de oportunidades para a construção de relações de confiança.

É importante salientar que o professor não constrói a relação sozinho, pois o posicionamento do aluno e sua disponibilidade para o encontro também constituem a relação. Entretanto, por sua intencionalidade e posição como organizador do ambiente social, entendemos que ele deve buscar alternativas para negociações que permitam que os alunos se mostrem no processo de ensino-aprendizagem, alternativas essas que deverão estar pautadas em bases de confiança, valorização e respeito. Algumas problematizações nos ajudam a pensar sobre esse tema e a direcionar nossa pesquisa: como os professores buscam conhecer seus 
alunos? Que aspectos da relação favorecem esse conhecimento? Nessa busca por conhecer os alunos o professor reconhece aspectos da subjetividade? $\mathrm{O}$ que o professor faz com esse conhecimento? Essas informações são inseridas na prática pedagógica? De que forma? Essas questões têm norteado a definição da investigação a que se propõe este trabalho.

Como já apresentado anteriormente no tópico destinado à revisão de literatura, apesar de haver muitas pesquisas sobre a relação entre professor e alunos, poucas têm concebido a aprendizagem como processo da subjetividade. $\mathrm{O}$ valor de proceder a uma investigação apoiada no referencial teórico aqui apresentado está relacionado à consideração do outro (professor, colegas) não apenas como facilitador do processo de aprendizagem, como algo externo, mas como parte constitutiva deste processo. 


\section{METODOLOGIA}

\subsection{A Epistemologia Qualitativa de González Rey}

"Os maiores aprendizados estão pelo caminho e não na chegada."

A subjetividade como definição ontológica, a partir da compreensão das formas de organização da subjetividade social no sujeito individual, traz diversas implicações para a pesquisa. O estudo da subjetividade permite a compreensão tanto sobre os sujeitos como dos espaços sociais em que eles participam. Entretanto a subjetividade não aparece de forma imediata ao pesquisador, já que configurações subjetivas e sentidos subjetivos não correspondem de forma linear e direta às expressões do sujeito. A partir dessas implicações e fazendo uma crítica contundente às perspectivas de pesquisa em psicologia apoiadas na lógica positivista González Rey desenvolve a Epistemologia Qualitativa como alternativa epistemológica e metodológica para o estudo do homem a partir de um processo diferente de construção do conhecimento. Nas palavras de González Rey (2002, p.24):

A definição de uma "epistemologia qualitativa", expressão que pode parecer redundante perante o fato de que toda epistemologia como construção dos processos do conhecimento é qualitativa, demanda significação ante a necessidade de especificar epistemologicamente o qualitativo.

Nesta perspectiva, a compreensão do qualitativo não requer apenas uma mudança das questões instrumentais, mas uma definição epistemológica dos processos de construção do conhecimento, que significam uma maneira diferente de fazer ciência assumindo o caráter histórico-cultural do conhecimento como construção humana. O desenvolvimento da Epistemologia Qualitativa como alternativa epistemológica para a pesquisa qualitativa em psicologia se deu em relação com o estudo da subjetividade humana, que trouxe novas exigências para as formas de produzir conhecimento.

Em primeiro lugar, a ciência não é só racionalidade, é subjetividade em tudo o que o termo implica, é emoção, individualização, contradição, enfim, é expressão íntegra do fluxo da vida humana, que se realiza através de sujeitos individuais, nos quais sua experiência se concretiza na forma individualizada de sua produção. O social surge na rota única dos indivíduos constituídos em uma sociedade e uma cultura particular. (GONZÁLEZ REY, 2002, p. 28)

A consideração da subjetividade em ciências sociais se faz fundamental pela própria natureza dos objetos que, sendo ao mesmo tempo sujeitos, não podem ser estudados fora da complexidade que os constitui. Considerar o estudo da subjetividade significa compreendê-la 
como parte constitutiva do indivíduo e dos diferentes espaços sociais, onde a realidade apresenta-se de forma plurideterminada, irregular, contraditória, histórica e interativa, fato que traz novas necessidades para o processo de pesquisa. (GONZÁLEZ REY, 2002)

Essa abordagem recupera o lugar das construções teóricas no processo de pesquisa e do pesquisador enquanto sujeito do pensamento, compreensões que trazem relevantes consequências metodológicas que se apoiam em três princípios: o conhecimento como produção construtivo-interpretativa, o caráter interativo e dialógico do processo de construção do conhecimento e a legitimação do singular na produção do conhecimento.

O caráter construtivo-interpretativo do conhecimento se refere à necessidade de o pesquisador dar sentido às informações que aparecem no momento empírico da pesquisa, processo que ocorre através das suas interpretações que, em constante confrontação com a teoria, apresentando construções sobre a realidade investigada. Não se trata de encaixar as manifestações dos sujeitos participantes da pesquisa em categorias estabelecidas a priori, mas de atribuir significados que abrem novas zonas de sentido sobre a realidade investigada.

\footnotetext{
Ainda que toda interpretação seja uma construção, há construções geradas pelo curso das ideias que se combinam no pensamento do pesquisador, que têm uma relação mais indireta e implícita com o problema estudado que aquela que caracteriza a interpretação. [...] O pesquisador, como sujeito, produz ideias ao longo da pesquisa, em um processo permanente que conta com momentos de integração e continuidade de seu próprio pensamento [...] (GONZÁLEZ REY, 2002, p. 33)
}

O caráter interativo e dialógico do processo de construção do conhecimento atribui fundamental importância para a relação entre os sujeitos da pesquisa, considerando a comunicação como via privilegiada para o estudo dos processos de subjetividade que acompanham os sujeitos e, assim, entender como a vida das pessoas é afetada por determinadas condições objetivas. Este princípio novamente reivindica o papel ativo do pesquisador que deve criar um clima favorável à comunicação a partir do envolvimento dos participantes, já que os problemas sociais se expressam na comunicação, seja por via direta ou indireta, que será de fundamental importância para a produção de zonas de sentido pelo pesquisador. O caráter dialógico da investigação recupera os participantes como sujeitos da pesquisa e não apenas como objeto de estudo. O pesquisador e as relações estabelecidas com os sujeitos participantes da pesquisa passam a ser os protagonistas do processo investigativo. (GONZÁLEZ REY, 2005)

O terceiro princípio, a legitimação do singular na produção do conhecimento, recupera a importância qualitativa da singularidade dos indivíduos, que pode ser entendida como forma única e diferenciada de constituição subjetiva, o que confere legitimação a um caso singular estudado. Tal legitimação se justifica pela importância das informações provenientes de um 
caso singular para a produção teórica em desenvolvimento. Segundo González Rey (2003, p. 270), "o caso individual proporciona informação que ganha significação dentro do processo de construção teórica que já está em desenvolvimento pelo investigador no momento em que se encontra com o caso estudado".

Considerando esses princípios a pesquisa não se apresenta como ritual padronizado de procedimentos, mas como processo. A pesquisa qualitativa se apresenta como via para a produção de modelos teóricos, que podem ser entendidos como a construção de sistemas de representações capazes de gerar inteligibilidade sobre a realidade. A teoria possui dois níveis relacionados entre si: nível macro que organiza as representações com certa estabilidade e abrangência, mas em sistemas abertos em constante desenvolvimento; e um nível local, comprometido com o empírico, onde gera suas próprias representações e conceitos. (GONZÁLEZ REY, 2003)

O momento empírico é inseparável do momento teórico e a tensão permanente entre esses dois momentos a partir do posicionamento ativo e reflexivo do pesquisador conduz a construções teóricas, que são as produções permanentes de ideias a partir de indicadores que vão adquirindo significado no curso da pesquisa que levam a novas zonas de sentido sobre o objeto investigado. Essas zonas de sentido, possíveis a partir das construções interpretativas do pesquisador, geram visibilidade a aspectos da realidade que antes estavam ocultas. As construções teóricas integrarão o modelo teórico mais amplo em desenvolvimento como momentos de continuidade e ruptura.

As teorias são modelos de significação que permitem construir versões sobre a realidade estudada, são produções humanas, representações possíveis do real e não o seu reflexo. As novas construções teóricas podem conduzir a novas representações da realidade. O momento empírico em constante relação e tensão com a teoria possui múltiplas alternativas de inteligibilidade e significação, onde o pesquisador faz opções que vão definir o curso da produção teórica sobre o objeto. Esse processo, definido como lógica configuracional, integra as construções do pesquisador com os fatos da realidade estudada e está em constante desenvolvimento, onde a emergência de novos elementos e ideias pode implicar mudanças no curso da pesquisa. Essa categoria representa o processo dinâmico, personalizado e constante de produção teórica, onde o pesquisador organiza a diversidade de ideias em eixos teóricos. (GONZÁLEZ REY, 2002)

Ao iniciar a pesquisa, entendida como processo de produção de conhecimento, o pesquisador se apoia em uma teoria que possui certo nível de consolidação e oferece ao pesquisador as bases para as construções teóricas e a proposição de modelos teóricos que gerem 
inteligibilidade sobre a questão investigada. A teoria possui além de categorias e princípios gerais, uma orientação metodológica, já o modelo teórico representa uma explicação, uma proposição, uma proposta explicativa elaborada pelo pesquisador para dar conta do objeto investigado e que vai abrindo novos campos de significação desse objeto a partir das zonas de sentido geradas. Nesse processo ocorre uma tensão constante entre a teoria e o momento empírico, onde o pesquisador, a partir das construções interpretativas elabora modelos teóricos de representação da realidade. Tal processo exige a atenção constante do pesquisador e seu posicionamento ativo como sujeito.

\subsection{Delineamento metodológico}

Em consonância com o referencial teórico assumido, a presente pesquisa adota a Epistemologia Qualitativa como referencial epistemológico e metodológico por compreender ser a opção mais adequada para o estudo de realidades complexas e plurideterminadas como é o caso da relação entre professor e alunos. Neste momento, retomamos os objetivos do estudo, já apresentados na introdução, e em seguida apresentamos como se pretende realizar a investigação para alcance dos objetivos propostos.

\section{Objetivo Geral:}

- Investigar os modos como a professora busca conhecer as especificidades dos alunos na dinâmica relacional da sala de aula, bem como identificar de que maneira esse conhecimento orienta a organização do trabalho pedagógico.

Objetivos Específicos:

1) Analisar o desenvolvimento das relações entre professora e alunos na sala de aula, identificando as bases pelas quais elas se constituem.

2) Identificar as formas como a professora age e cria canais comunicativos com a turma e com os alunos individualmente.

3) Conhecer aspectos que constituem a subjetividade individual da professora, bem como a articulação destes aspectos para a compreensão das relações construídas com os alunos. 


\subsubsection{Escolha dos participantes e construção do cenário social da pesquisa}

A perspectiva da Epistemologia Qualitativa atribui fundamental importância a construção do cenário social de pesquisa, entendido como "a fundação daquele espaço social que caracterizará o desenvolvimento da pesquisa e que está orientado a promover o envolvimento dos participantes." (GONZÁLEZ REY, 2005, p. 83) Neste processo, as pessoas tomarão a decisão de participar ou não da investigação, sendo assim, é necessário que o pesquisador busque estabelecer uma relação de confiança com os participantes, não apenas para obter sua aceitação, mas principalmente sua efetiva participação em um clima comunicativo e reflexivo. A seguir apresenta-se como se deu a escolha pela escola e pelos participantes, bem como o início da construção do cenário de pesquisa.

Inicialmente, teve-se como delimitação a escolha por uma escola pública de uma Região Administrativa do Distrito Federal que atendesse as séries iniciais do Ensino Fundamental e tivesse o acompanhamento de professores atuando no Bloco Inicial de Alfabetização $\left(1^{\circ}\right.$ ao $3^{\circ}$ anos). A escolha pelo Bloco Inicial de Alfabetização se justifica pelo interesse pessoal da pesquisadora nesse nível de ensino e por ser este o momento inicial em que as relações entre professor e alunos se constituem numa maior formalização devido às exigências curriculares, já que antes dessa etapa - na Educação Infantil - há uma maior flexibilização do currículo. Apesar disso, consideramos que nesta fase há mais condições de haver maior envolvimento entre professores e alunos, visto que apenas um professor se encontra responsável pela turma diariamente. Entretanto, considerando a complexidade dos processos relacionais, destacamos que nem sempre isto acontece, já que estar presente em um mesmo espaço físico não garante o envolvimento ativo entre pessoas.

Após essas definições decidimos a princípio acompanhar duas professoras e suas turmas. Para proceder à escolha dos participantes da pesquisa iniciamos uma conversa com algumas professoras da Secretaria de Estado de Educação do Distrito Federal que haviam sido orientadoras do curso do PNAIC (Pacto Nacional pela Alfabetização na Idade Certa) e, devido a isso, tinham contato com diversos professores da rede pública de ensino. Nessa conversa inicial foram apresentados os objetivos da pesquisa e pedimos a indicação de possíveis colaboradores que se encaixassem nos seguintes critérios: professores que atuavam no Bloco Inicial de Alfabetização; professores que demonstravam ser abertos à participação em uma pesquisa; professores que durante o curso PNAIC demonstravam, de alguma forma, uma preocupação com a sua relação com os alunos. 
Após a sondagem inicial e passado o período de greve e reposição das aulas, optamos por iniciar a pesquisa em uma escola que tinha pelo menos duas professoras que foram indicados e que se localizava numa região mais central da cidade de Planaltina, Distrito Federal. O contato inicial com a escola foi realizado na primeira semana de aula do ano letivo de 2016, no início do mês de março, a partir de uma conversa com a direção e a entrega de uma Carta de Apresentação (apêndice A). A pesquisadora explicou que tinha recebido a indicação de duas professoras para participarem da pesquisa, ao passo que a diretora informou que uma dessas professoras estava atuando com o $1^{\circ}$ ano do Ensino Fundamental, mas que a outra indicada não estava atuando com turmas do Bloco Inicial de Alfabetização. Sendo assim, a própria diretora sugeriu outra professora, também de $1^{\circ}$ ano do Ensino Fundamental, para participar da pesquisa.

Em seguida, iniciamos uma conversa com as duas professoras indicadas onde apresentamos o estudo e esclarecemos aspectos da dinâmica da pesquisa. As duas professoras demonstraram, prontamente, interesse na participação. Com essa aceitação foi feito o registro no Termo de Consentimento Livre e Esclarecido (apêndice B) e acordado a data para início das atividades.

As situações descritas demonstram apenas o início da aproximação com os participantes da pesquisa, entretanto, há que se ter em mente que o cenário social da pesquisa não é um momento estático e permanece em manutenção ao longo de todo o processo de investigação, a partir da construção de um espaço de relações (ROSSATO; MARTINS; MARTINEZ, 2014). Neste sentido, iniciamos a pesquisa acompanhando duas professoras de $1^{\circ}$ ano do Ensino Fundamental e suas respectivas turmas, no entanto, no decorrer da investigação optamos por continuar com apenas uma professora e sua respectiva turma, por apresentarem mais elementos que nos auxiliavam na construção da informação, além de demonstrar um envolvimento maior com a pesquisa.

Faz-se necessário esclarecer que o referencial epistemológico adotado requer um envolvimento ativo do participante da pesquisa com o objeto de estudo, o que traz também ao pesquisador o desafio de buscar a construção de uma relação dialógica com os participantes. A partir do envolvimento inicial com as duas turmas, optou-se por prosseguir com apenas uma delas para permitir o maior aprofundamento das questões investigadas. Segundo González Rey (2005, p.111), no processo de pesquisa

[...] os sujeitos não são escolhidos ao acaso, mas eleitos entre os que tiveram uma participação mais significativa em relação aos objetivos da pesquisa. Os sujeitos individuais selecionados serão uma via essencial para o aprofundamento das informações implicadas no desenvolvimento do modelo teórico em construção. 
Dessa forma, a pesquisa foi realizada a partir de um estudo de caso com uma professora, a quem demos o nome fictício de Alice, e sua respectiva turma de $1^{\circ}$ ano do Ensino Fundamental. Esse estudo de caso permite o estudo da singularidade dos sujeitos envolvidos na pesquisa, bem como de um grupo social, que nos forneceu importantes informações sobre as subjetividades individual e social. Como salienta González Rey (2012), não é a quantidade de sujeitos estudados que legitima o conhecimento científico, mas a qualidade da sua expressão, em que as informações provenientes de um caso singular adquirem legitimidade pela construção do modelo teórico do pesquisador.

Consideramos, então, que o estudo de caso com uma professora sua turma seria a opção mais adequada para a investigação dos processos relacionais entre professor e alunos na sala de aula, visto que nos auxiliaria a ter uma compreensão mais aprofundada dos múltiplos aspectos que constituem este processo.

\subsubsection{Produção da informação - instrumentos da pesquisa}

Na Epistemologia Qualitativa a construção de indicadores se dá a partir dos momentos formais e informais da pesquisa, onde tem relevante papel a utilização dos instrumentos que permitam a comunicação e a expressão dos participantes. Os instrumentos são entendidos como "toda situação ou recurso que permite ao outro expressar-se no contexto de relação que caracteriza a pesquisa". (GONZÁLEZ REY, 2010, p. 42) Dessa forma, os diferentes instrumentos apresentam-se como uma ferramenta interativa e formam um sistema relacionando-se uns com os outros e permitindo a expressão de informações significativas em mais de um momento.

Na presente pesquisa, utilizou-se os seguintes instrumentos:

- Dinâmicas conversacionais - entendido como todo espaço de conversação, incluindo os momentos informais, que coloca a relação com outro como momento permanente da pesquisa. As dinâmicas conversacionais foram realizadas com os professores e com os alunos, perpassando todos os momentos e espaços da pesquisa, incluindo momentos previamente planejados pela pesquisadora e momentos não planejados em que surgia a oportunidade de diálogo. Vale ressaltar que durante a presença da pesquisadora na escola houve diversas oportunidades de desenvolvimento de dinâmicas conversacionais devido ao vínculo estabelecido com a professora e os alunos. 
- Entrevista semiestruturada - objetiva a expressão das reflexões dos participantes da pesquisa a partir das problematizações do pesquisador e complementa de forma sistemática os sistemas conversacionais. Nesse momento o pesquisador pode aprofundar aspectos observados em outros instrumentos para consolidar a construção dos indicadores. Neste trabalho, a entrevista foi realizada para conhecer melhor o percurso profissional da professora, suas justificativas para as formas como assume a organização do trabalho pedagógico, o modo como ela percebe seus alunos e sua turma, além de outras informações pertinentes ao desenvolvimento da pesquisa. A entrevista foi realizada ao final do $1^{\circ}$ bimestre letivo, momento em que a pesquisadora já estava na escola há dois meses (apêndice C).

- Complemento de frases - instrumento criado por González Rey (2005), apresenta indutores curtos a serem completados pelos participantes e permitem a expressão de sentidos subjetivos provenientes de diversas áreas e contextos. A escolha deste instrumento nesta pesquisa teve a finalidade de conhecer aspectos da constituição subjetiva da professora, bem como a articulação destes aspectos para a compreensão das relações construídas com os alunos. O complemento de frases foi realizado no terceiro mês da pesquisa (apêndice D).

- Observação/envolvimento por convivência cotidiana - permite identificar comportamentos intencionais e não intencionais envolvidos na configuração da realidade investigada. A observação foi realizada a partir de um planejamento dos aspectos que se desejava observar. Além disso, a pesquisadora se ateve a momentos descritivos e explicativos, que envolviam sua percepção, suas ideias, problematizações, impressões, etc, que foram articuladas aos outros instrumentos para a construção dos indicadores. As observações foram registradas em um diário de bordo. Um procedimento que se tornou interessante e produtivo na investigação foi que, a cada observação realizada, a pesquisadora elencava questões e aspectos para serem aprofundados nas observações seguintes. Algumas dessas questões, puderam ser discutidas com a professora em dinâmicas conversacionais no mesmo dia da observação, em momentos mais livres tais como o recreio ou horário de parque e quadra. Devido ao envolvimento com os participantes da pesquisa, nestas observações cotidianas era possível realizar diversos momentos de dinâmicas conversacionais no curso das ações observadas. No decorrer da pesquisa, os próprios alunos e a professora 
colaboradora iniciavam diálogos com a pesquisadora sobre as atividades realizadas na escola. Essa articulação entre observação e dinâmicas conversacionais trouxe importantes informações que auxiliaram na construção dos indicadores. Participamos dos seguintes contextos:

- DINÂMICA RELACIONAL NA SALA DE AULA - foram considerados todos os momentos que envolvem o desenvolvimento das aulas, incluindo o espaço da sala de aula, biblioteca, parquinho, pátio, dentre outros, observando: como se desenvolve a rotina das aulas; de que modo professor e alunos se relacionam na prática pedagógica; como os professores se dirigem aos alunos; como os alunos reagem às posturas do professor; como o professor conduz as atividades; em que momentos professor e alunos têm uma maior aproximação; como o professor busca solucionar dúvidas e conflitos; como, porquê e em que momentos o professor busca se aproximar dos alunos; de que maneira o professor busca conhecer os alunos e que aspectos privilegia nesse processo; como se estabelece os turnos de fala e os processos de negociação; de que maneira o professor intercala a atenção ao coletivo e ao individual durante as atividades realizadas; qual a postura do professor e dos alunos durante a realização das diferentes atividades propostas; como é o "clima" da sala de aula; dentre outras situações pertinentes aos objetivos da pesquisa.

- COORDENAÇÃO PEDAGÓGICA - realizada de duas a três vezes por semana em horário inverso ao horário de aula, onde os professores fazem estudos e planejamento de como serão as aulas. Neste momento observamos: como a professora se refere aos alunos; como discute os encaminhamentos das aulas; o que prioriza na seleção das atividades a serem desenvolvidas; como busca estratégias para solução dos problemas identificados; se insere no planejamento o conhecimento que tem de seus alunos; se insere no planejamento das aulas momentos que possibilitem a maior aproximação e conhecimento dos alunos; se faz algum tipo de adaptação ao planejamento de acordo com as especificidades dos alunos; dentre outras situações relevantes.

- CONSELHO DE CLASSE - realizado bimestralmente entre os professores, equipe pedagógica e equipe gestora. Participamos de dois momentos de 
conselho de classe, referente ao $1^{\circ}$ e $2^{\circ}$ bimestres, em que observamos os assuntos e temas que foram privilegiados; como os professores e equipe gestora demonstram ter conhecimento dos alunos que eram citados e de que maneira buscaram possíveis encaminhamentos para conflitos não solucionados, dentre outros aspectos.

- MOMENTOS NÃO-FORMAIS - os intervalos das aulas no pátio da escola e na sala dos professores, horário de entrada e saída dos alunos, festas e eventos, são ricas oportunidades de se observar as posturas de professor e alunos em momentos mais livres e, ainda de buscar uma maior aproximação com os mesmos. Destacamos a participação no passeio ao Centro Cultural Banco do Brasil, na Festa da Família, na festa de encerramento do projeto "Contanto Histórias, Formando Leitores" e na festa de aniversário de um aluno que teve a presença de toda a turma. Estes momentos foram fundamentais para conversas com familiares dos alunos, com os alunos e com a professora, favorecendo a consolidação de alguns indicadores que já haviam sido levantados pela pesquisadora sobre o funcionamento da turma de acordo com a dinâmica relacional estabelecida naquele espaço social.

- Análise documental - foi realizada a partir da análise dos escritos que envolvem a prática pedagógica e que não foram desenvolvidos pela pesquisadora, mas pelos participantes. Os escritos incluíram tanto materiais mais informais como: murais, cartazes, bilhetes dos alunos, fotografias, dentre outros; tanto os formais, utilizados oficialmente na instituição escolar como forma de organização do trabalho pedagógico. Em relação aos documentos formais fizeram parte da pesquisa:

- RELATÓRIO DOS ALUNOS - realizado ao final de cada bimestre pelo professor, apresenta de forma descritiva o desenvolvimento do aluno naquele período. O relatório é apresentado aos pais e compõe a pasta do aluno que fica na secretaria e acompanha toda a vida escolar do estudante. A análise dos relatórios teve como objetivo conhecer aspectos que a professora privilegia nesse momento e como ele percebe o desenvolvimento e aprendizagem dos alunos. 
- FICHA DO CONSELHO DE CLASSE - é preenchida ao final de cada bimestre pelo professor em discussão com a equipe pedagógica e apresenta as principais dificuldades e avanços da turma, além do registro dos alunos que necessitam de algum tipo de intervenção. $\mathrm{O}$ documento apresenta ainda possíveis encaminhamentos para o bimestre seguinte.

- OUTROS - no desenvolvimento da pesquisa houve ainda a análise de outros materiais, tais como: caderno dos alunos, atividades realizadas pelos alunos, murais e caderno de planejamento do professor.

- Redação - trata-se de um registro escrito, que representa uma importante via de produção de trechos de informação, visto que possibilita um envolvimento reflexivo do participante da pesquisa. (GONZÁLEZ REY, 2005) Pediu-se que a professora realizasse uma redação com o título "Eu e minha turma" e foi esclarecido que ela poderia escolher qualquer gênero para escrita (apêndice E). Essa proposição de caráter mais aberto é fundamental para o posicionamento ativo do participante, que será fonte de indicadores de sentidos subjetivos envolvidos com o objeto da pesquisa.

Os instrumentos acima descritos foram planejados inicialmente, quando da elaboração do projeto de pesquisa. Todavia, no decorrer do processo de investigação, no curso do processo construtivo da pesquisadora, surgiu a necessidade de acrescentar outros recursos, tais como:

- Dinâmica conversacional sobre o complemento de frases - após a realização do complemento de frases levantamos alguns indicadores sobre a constituição subjetiva da professora. Com o objetivo de aprofundar nossa construção interpretativa, propomos ao final da pesquisa um momento de conversação sobre os seguintes temas que emergiram no complemento de frases: infância; história de vida; família; local de trabalho.

- Publicações em redes sociais - a partir do envolvimento com a professora, as redes sociais se tornaram uma importante fonte de informação da pesquisa. Utilizou-se o facebook $^{4}$ com o objetivo de conhecer as situações vividas pela professora, bem como

\footnotetext{
${ }^{4} \mathrm{O}$ facebook é uma rede social que permite aos usuários divulgar mensagens, fotos e vídeos formando um mural. Cada publicação, chamada de post, dos diferentes usuários que estão conectados fica disponível em um "feed de notícias”. Os usuários podem interagir fazendo comentários nas publicações e trocando mensagens privadas.
} 
suas publicações sobre posicionamento pessoal sobre assuntos diversos, tais como: política, educação, infância, mídias sociais, etc. Além disso, a professora utilizava o facebook para divulgar situações do seu trabalho pedagógico com a turma, onde era possível, ainda, ter acesso aos comentários de colegas de trabalho e pais de alunos. Além


e participante, visto que conversávamos sobre os momentos vivenciadas na sala de aula, situações e comentários inusitados feitos pelos alunos na ausência da pesquisadora. Em alguns momentos, os alunos chegaram a mandar mensagem de áudio para a pesquisadora através do whatsapp da professora. Para além das informações produzidas, as redes sociais foram meios que favoreceram o vínculo entre a pesquisadora e a turma investigada.

- Dinâmica conversacional com os alunos a partir de uma história - nas observações cotidianas, a partir do vínculo estabelecido com a turma, as dinâmicas conversacionais com os alunos era algo rotineiro. Mesmo assim, optamos por criar um momento específico com o objetivo de conhecer os momentos que os alunos mais gostavam nas aulas, bem como suas opiniões e comentários sobre a professora. Este instrumento foi realizado com grupos de 10 alunos, sem a presença da professora, onde a pesquisadora contou a história "Uma professora muito maluquinha", de Ziraldo, e, em seguida, abriuse espaço para diálogo sobre a história e sobre a realidade vivenciada por eles na turma (apêndice F).

A utilização dos diferentes instrumentos elencados se justifica para garantir diversas possibilidades de expressão dos sujeitos, facilitando o trânsito por zonas distintas de experiências que estimulem a implicação subjetiva dos participantes da pesquisa. Além disso, a articulação entre as informações dos diversos instrumentos permite a construção de indicadores com a consolidação ou abandono de determinada hipótese de trabalho, que será base para a compreensão do problema investigado.

\footnotetext{
${ }^{5} \mathrm{O}$ whatsapp é um aplicativo de mensagens instantâneas para celulares. Com ele, o usuário pode trocar mensagens com seus contatos telefônicos que também possuam o aplicativo. Os usuários do whatsapp podem trocar, ainda, fotos, vídeos e gravações de áudio.
} 


\title{
6. O PROCESSO CONSTRUTIVO INTERPRETATIVO: A RELAÇÃO PROFESSORA-ALUNOS COMO BASE DO CONTEXTO PEDAGÓGICO
}

\begin{abstract}
"A diferença entre professores e educadores está no olhar. Os olhos dos professores olham primeiro os saberes. Seu dever é cumprir o programa. Depois eles olham para os alunos, para ver se eles aprenderam os saberes. Para professores, saberes são fins, alunos são meios. Os olhos dos educadores, ao contrário, olham primeiro para os alunos. Eles querem que os alunos 'degustem' os saberes. Todo saber deve ser saboroso."
\end{abstract}

Rubem Alves

Na Epistemologia Qualitativa o processo de construção da informação representa uma tensão constante entre o momento empírico e a teoria que sustenta a pesquisa. Diferentemente de outras epistemologias, a construção do pesquisador não ocorre apenas ao final da pesquisa, após a "coleta de dados", pois, como já foi destacado, as informações do campo empírico não estão prontas e acabadas, mas devem ser interpretadas pelo pesquisador que vai elaborando hipóteses de trabalho e construindo indicadores sobre o objeto de estudo. Dito isto, é fundamental que se tenha em mente que, apesar de ser apresentada em um capítulo final, por uma questão de estrutura de texto, a construção interpretativa da pesquisadora foi realizada durante toda a pesquisa, com um caráter processual e contínuo.

Neste capítulo, apresentamos o modelo teórico produzido, articulando as informações do campo empírico com a produção intelectual da pesquisadora, que representa processos de significação que foram sendo produzidos no curso da pesquisa e vão além dos fatos manifestos.

Sendo assim, inicialmente apresentamos o contexto de realização da pesquisa, trazendo informações sobre a escola, a professora, a turma e a rotina das aulas. Em seguida, apoiamos nossas construções em três tópicos:

1) Bases que constituem a relação professora-alunos - neste tópico apresentamos temas que consideramos ser os princípios que estão na base das relações que foram construídas entre a professora Alice e seus alunos. Discutimos, ainda, aspectos sobre os processos de comunicação e os modos como a professora buscava conhecer as especificidades dos alunos na sala de aula.

2) Aspectos da constituição subjetiva da professora Alice e sua articulação para a compreensão das relações estabelecidas com os alunos - neste tópico trazemos alguns elementos da constituição da subjetividade individual da professora Alice e fazemos uma articulação com os princípios apresentados no tópico anterior. 
3) Síntese integrativa dos aspectos analisados: respondendo aos objetivos da pesquisa - este último tópico apresenta uma síntese que articula os tópicos anteriores.

Faz-se necessário esclarecer que esta organização, bem como os temas destacados no primeiro item, não estava estabelecida a priori, antes do início da pesquisa. Os temas que compõem o item 1, que consideramos estar na base da constituição da relação professor-aluno, foram construídos a partir da interpretação do contexto pedagógico investigado e a relação entre os indicadores levantados. Dentre estes temas, alguns se relacionam mais às concepções da professora, outros às formas de definir o trabalho pedagógico e outros aos modos de relação entre professora e alunos. Entretanto, optamos por apresenta-los de maneira temática, como descrito no quadro, sem fazer uma classificação destes tópicos, pois consideramos que estes aspectos se articulam de maneira complexa, formando uma unidade que constitui um modo singular de funcionamento da turma investigada. Essa discussão será aprofundada na apresentação de cada tema.

A escola

A instituição educativa em que a realizamos a pesquisa atendia turmas de Educação Infantil e de $1^{\circ}$ ao $5^{\circ}$ ano do Ensino Fundamental. A escola fica localizada no perímetro urbano de uma Região Administrativa do Distrito Federal e atende alunos da quadra residencial em que fica situada e de alguns bairros periféricos vizinhos.

No ano da pesquisa a escola atendia 684 alunos, totalizando 28 turmas. Em relação a estrutura física contava com dois blocos de sala de aula, sendo um bloco destinado às turmas de Educação Infantil e Bloco Inicial de Alfabetização ( $1^{\circ}$ ao $3^{\circ}$ anos) e outro bloco destinado às turmas de $4^{\circ}$ e $5^{\circ}$ anos. Logo à entrada da instituição se situavam a secretaria, a direção, a sala dos professores e a sala de apoio especializado. ${ }^{6}$ A instituição possuía ainda um pátio grande; uma quadra; um parque de areia; uma área verde com árvores; uma sala de leitura; uma sala de informática que, naquele ano estava desativada devido a problemas técnicos; uma sala de recursos para atendimento dos alunos com necessidades educacionais especiais; além de cantina e depósito de materiais.

O grupo de profissionais da escola era formado por 56 servidores, sendo secretária escolar, professores das turmas regulares, uma pedagoga, uma psicóloga escolar, uma

\footnotetext{
${ }^{6} \mathrm{~A}$ sala de apoio especializado contava com uma equipe multifuncional formada por uma pedagoga, uma psicóloga e uma orientadora educacional.
} 
orientadora pedagógica, uma diretora, uma vice-diretora, um supervisor administrativo, uma coordenadora pedagógica, uma monitora e dois professores da Sala de Recursos ${ }^{7}$ (quantidade justificada pelo número de alunos ANEE atendidos pela escola). Os servidores responsáveis pela limpeza e pela alimentação pertenciam ao quadro de uma empresa terceirizada. Apesar de contar com uma equipe completa no Serviço de Apoio Especializado (pedagoga, psicóloga e orientadora educacional), fato raro nas escolas públicas do Distrito Federal, a escola enfrentava problemas relativos aos recursos humanos. No início do ano letivo a equipe gestora ficou desfalcada sem a figura de uma vice-diretora por quase dois meses. Além disso, pelo quantitativo de alunos a escola tinha direito a três coordenadores pedagógicos, entretanto durante todo o ano letivo a instituição contou apenas com uma coordenadora já que não haviam outros professores que se interessavam em ocupar tal cargo. ${ }^{8}$

A organização da escola se dava de maneira semelhante a outras escolas públicas deste nível de ensino, em que em um turno os professores estavam em regência com suas turmas e no turno contrário na coordenação pedagógica. Um dia da semana era dedicado à coordenação coletiva, onde havia reunião com a equipe gestora, estudos e discussão de assuntos administrativos. Os outros dias da semana eram reservados ao planejamento pedagógico das aulas. Neste momento haviam duas situações: professores de uma mesma série que se reuniam para planejar em conjunto as situações de aprendizagens que seriam desenvolvidas com as turmas; e professores que realizavam o planejamento de maneira individual, sem a troca de experiências com os colegas. No geral, percebemos que no momento do planejamento pedagógico não havia uma estratégia em nível amplo ou um projeto para toda a escola. $\mathrm{O}$ fato de não haver a figura de um supervisor pedagógico e apenas uma coordenadora pedagógica que, constantemente estava em sala de aula substituindo professores em licença médica ou cumprindo outras demandas, dificultava a elaboração de um projeto comum para toda a escola e um planejamento pedagógico mais coletivo e co-participativo. Dessa forma, cada professor realizava seu planejamento da maneira que achava adequada.

Apesar dessa dificuldade, que também está presente em diversas outras instituições educativas do DF, nos momentos de realização de eventos, festas e atividades que abrangiam toda a escola percebemos que todos os profissionais se envolviam ativamente, contribuindo para a qualidade do evento. Destacamos, ainda, a atuação da diretora que estava sempre

\footnotetext{
${ }^{7}$ A sala de recursos oferece um serviço de natureza pedagógica complementar e suplementar ao realizado nas salas regulares com alunos com necessidades educacionais especiais. (DISTRITO FEDERAL, 2010)

${ }^{8}$ Destacamos que o trabalho do coordenador pedagógico implica o desafio de trabalhar coletivamente. Esta dificuldade apresentada pela escola da pesquisa, bem como por outras escolas públicas do Distrito Federal, indica um aspecto da subjetividade social das instituições escolares.
} 
presente nos momentos de início das aulas, recebendo os alunos e participando dos momentos de acolhida, em que professores e crianças cantavam músicas e contavam histórias antes de ir para a sala de aula. Nestas ocasiões, a diretora interagia com os alunos e professores. Além disso, nos dias destinados ao planejamento pedagógico presenciamos diversos episódios em que a diretora ia conversar com as professoras sobre alguns alunos, às vezes demonstrando preocupação com algum episódio desagradável, outras vezes contando situações inusitadas e até mesmo perguntando como estava seu processo de aprendizagem.

Alguns trechos de informações retirados dos conselhos de classe nos auxiliam na interpretação de que a diretora da escola estava preocupada com a construção de um trabalho pedagógico de qualidade e que, de fato, tivesse implicações no desenvolvimento dos alunos.

Gente, não adianta ter o projeto do livro bonito, mas que o menino não fala, não dramatiza, fica engessado. Aí no $3^{\circ}$ ano o menino vira diplomado né, acabou o afeto. Ai fica falando o tempo todo: "Ah porque no $1^{\circ}$ ano e no $2^{\circ}$ não reprovou, mas agora reprova, viu”.

A sala de informática já está disponível para quem quiser dar reforço. Mas, gente, não adianta trazer o menino pro reforço pra dar a mesma folha que ele faz na sala de aula. É perda de tempo! Tem que ter atividades diferentes, lúdica, atrativas, tem que ter atividades diversificadas.

O que eu acho legal, Paloma (professora do $2^{\circ}$ ano), é que apesar de todas essas dificuldades com a turma, eles estão felizes contigo, que é nosso papel também, além do pedagógico. (Diretora, Conselho de Classe)

Os trechos destacados, juntamente com as informações anteriores, nos indicam que a diretora tinha um posicionamento crítico em relação a práticas pedagógicas padronizadas, além de tentar estar próxima à realidade concreta dos alunos. Entretanto, apesar das recomendações da diretora, devido às dificuldades já citadas, a escola não possuía um projeto pedagógico comum e conviviam simultaneamente grupos diferentes de professores: alguns com práticas mais padronizadas e tradicionais, outros sem uma definição clara de organização do trabalho pedagógico e alguns com práticas mais participativas e inovadoras.

Apresentar esse contexto é importante para compreendermos um pouco da organização da escola, fato que tem implicação na constituição da subjetividade social daquela instituição educativa. Neste cenário, os professores e suas turmas podem apresentar posturas significando tanto a reprodução da subjetividade social estabelecida, quanto a ruptura com processos de significação já consolidados, gerando novos espaços de subjetivação. 
A professora Alice

A professora a quem demos o nome fictício de Alice tinha 32 anos no momento da pesquisa, nasceu em uma fazenda, na zona rural do estado da Bahia, onde morou com a mãe e os seis irmãos durante a primeira infância. Em seguida mudou-se com a mãe e os irmãos para uma cidade pequena para poder estudar. Já adolescente, a família se mudou para uma Região Administrativa do Distrito Federal, a mesma onde se situa a escola onde realizamos a pesquisa e onde Alice morava no ano em questão.

No momento da pesquisa Alice estava recém separada e morava com seus dois filhos, um menino de 6 anos e uma menina de 9 anos, ambos estudavam na mesma escola em que ela trabalhava. Em relação à formação acadêmica, ela fez o curso de Magistério, formou-se em Pedagogia pela Universidade de Brasília e tinha acabado de finalizar uma Especialização em Educação Infantil, também pela Universidade de Brasília.

Alice é professora há 14 anos e já trabalhou naquela escola por cinco anos não consecutivos. Em sua trajetória profissional atuou com turmas de Educação Infantil, $1^{\circ}$ ano, $2^{\circ}$ ano, $5^{\circ}$ ano e Educação de Jovens e Adultos. Além disso, já atuou como supervisora pedagógica e coordenadora pedagógica. No entanto, ela relatou que sua preferência de atuação é em sala de aula, em turmas de Educação Infantil e $1^{\circ}$ ano do Ensino Fundamental.

Desde o primeiro contato com a escola, a professora Alice demonstrou bastante abertura em relação à pesquisa. Logo no início ela contou sobre suas experiências como pesquisadora no curso de especialização que havia realizado e os artigos que escreveu com base no trabalho final do curso. Manifestou o desejo de fazer Mestrado e estava sempre participando de congressos e eventos de Educação. Estes fatos facilitaram a construção de um vínculo entre pesquisadora e participante, já que Alice demonstrava interesse em conversar sobre o processo de pesquisa e a vida acadêmica.

Na escola, Alice era reconhecida pela equipe gestora, pelos colegas de trabalho e pelos pais de alunos por causa do trabalho pedagógico criativo e compromissado que realizava. Devido a tal reconhecimento, no ano da pesquisa Alice chegou a receber convites para ser Supervisora Pedagógica, mas recusou alegando que preferia atuar como professora e que não gostaria de abandonar sua turma.

Mais adiante, em um tópico específico, aprofundaremos essa análise com a discussão de aspectos da constituição subjetiva da professora Alice e sua articulação para a compreensão das relações estabelecidas com os alunos. 


\section{A turma}

A turma de $1^{\circ}$ ano do Ensino Fundamental, que tinha a professora Alice como regente, possuía 26 alunos, sendo dez meninas e dezesseis meninos. No decorrer da pesquisa uma aluna foi transferida e, algum tempo depois, outra aluna foi matriculada, preenchendo esta vaga. Os alunos tinham seis anos de idade e a grande maioria já estudava na escola no ano anterior, na turma de Educação Infantil referente à alunos com cinco anos de idade. Dessa forma, muitos já conheciam a professora Alice devido à sua participação em momentos de contação de histórias que envolviam toda a escola.

Minha presença na sala de aula foi percebida pelos alunos com naturalidade, possivelmente porque antes da minha chegada a professora teve uma conversa com a turma sobre a pesquisa. Com o passar do tempo e de acordo com a ampliação dos vínculos com os alunos eles iam fazendo perguntas mais específicas sobre os motivos de eu estar acompanhando a turma deles. De uma maneira geral, os alunos eram bastante comunicativos e participativos, gostavam de brincar, conversar e se movimentar pela sala.

A turma foi acompanhada durante seis meses, desde a segunda semana do início do ano letivo, dos meses de março a agosto. Neste período, a convivência cotidiana com a turma e a professora colaboradora se dava através de dois encontros semanais. O contato com a turma não se encerrou após esse período de seis meses, havendo ainda a nossa participação em alguns eventos na escola, como festa de aniversário de um aluno, comemoração da semana da criança, festa de encerramento do ano letivo, dentre outros.

\section{A rotina das aulas}

Para que o leitor compreenda melhor os aspectos que serão destacados sobre a dinâmica relacional na sala de aula faz-se necessário contextualizar as formas de organização do trabalho pedagógico da professora Alice. As escolhas pedagógicas realizadas no planejamento e as maneiras como os docentes organizam a rotina da turma não são neutras, revelando as concepções destes profissionais sobre educação, aprendizagem, desenvolvimento, criança, enfim, sobre aspectos que terão implicações nas relações construídas com os alunos. Mais do que revelar concepções, acreditamos que tais escolhas não estão desvinculadas das crenças, da história de vida, dos processos de formação, dos gostos e interesses, das emocionalidades geradas, ou seja, de toda uma configuração que faz parte da constituição subjetiva do professor. 
Sendo assim, serão explicitadas algumas práticas que faziam parte da organização do trabalho pedagógico da professora Alice e da rotina da sua turma. Em seguida, esses aspectos serão retomados juntamente com a análise das relações construídas entre professor e alunos na sala de aula.

* Planejamento: na escola em questão, o turno vespertino é composto por duas turmas de $1^{\circ}$ ano do Ensino Fundamental. Seguindo a organização da estrutura das escolas do Distrito Federal, os professores se dedicam à coordenação pedagógica, planejamento, cursos e estudos em horário inverso, ou seja, no período matutino. A professora Alice planejava as práticas que seriam desenvolvidas com a turma juntamente com a outra professora de $1^{\circ}$ ano. No início do ano letivo elas definiram dois projetos base para desenvolver com as turmas: 1) Contando histórias, formando leitores; 2) Gente tem nome e sobrenome. As duas professoras definiam juntas as histórias que seriam trabalhadas, os conteúdos e objetivos que poderiam ser abordados a partir daquelas histórias, as atividades que seriam desenvolvidas, bem como dividiam tarefas relativas às apresentações da história (escolha de personagens, cenário, figurino, etc). Apesar de terem a mesma base de planejamento, as professoras realizavam atividades diferentes de acordo com as necessidades de cada turma. A professora Alice elaborava as atividades de sistematização a partir das possibilidades geradas pelas histórias escolhidas, relacionando os aspectos operacionais dos conteúdos aos temas discutidos em sala. Além das atividades sistematizadas, que envolviam o registro dos alunos, eram elaboradas ainda atividades, como jogos, brincadeiras, atividades de psicomotricidade, rodas de conversa, dentre outras. Dessa forma, elas não recorriam a atividades padronizadas encontradas em livros e apostilas, mas criavam as atividades de acordo com as necessidades da turma naquele momento e sempre contextualizando com um tema mais amplo, demonstrando assim um processo de autoria.

* Rotina das aulas

\section{Quadro 2 - Organização semanal das aulas 9}

\footnotetext{
${ }^{9} \mathrm{O}$ quadro foi representado a partir de uma foto tirada do caderno de planejamento da professora e é possível notar a escrita dos alunos. Optamos por apresentar o quadro desta forma, pois entendemos que esta situação se apresenta como um indicador de como eram as relações entre professora e alunos, já que as crianças tinham livre acesso à mesa da professora, sem que isso gerasse algum tipo de situação adversa.
} 


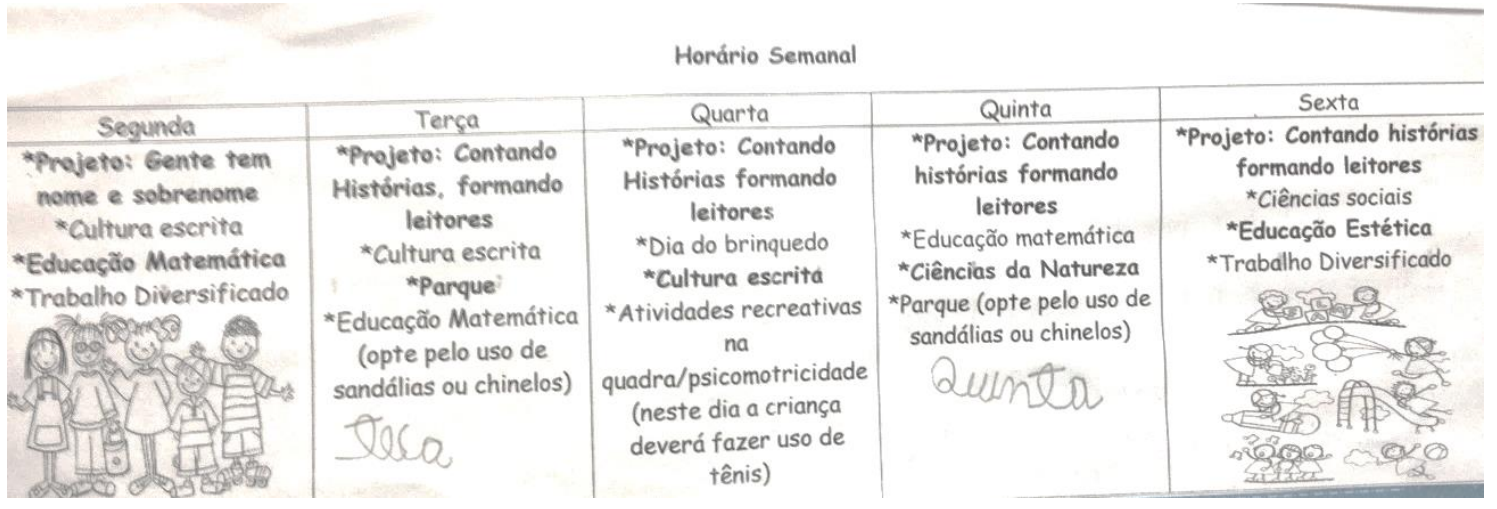

- Acolhida no pátio: ao chegar à escola os alunos guardavam os materiais na sala de aula e seguiam para o pátio, onde sentavam no chão, cada turma disposta em duas fileiras de meninos e meninas. Participavam desse momento todas as turmas do Bloco Inicial de Alfabetização ( $1^{\circ}$ ao $3^{\circ}$ ano do Ensino Fundamental) e as turmas da Educação Infantil (que no turno vespertino eram duas). Quando batia o sinal todas as professoras se reuniam à frente do grupo para dar boas-vindas aos alunos, cantar algumas canções do universo infantil, ensinar brincadeiras musicadas, dentre outras atividades de preparação para o início da aula. Era um momento bastante animado que os alunos participam ativamente. Percebemos a participação ativa da diretora neste momento, que além de auxiliar na organização fazia questão de cantar e dançar com os alunos, demonstrando descontração e aproximação com os mesmos. Notamos ainda uma atitude de liderança da professora Alice, que sempre se mostrava bastante animada e por diversas vezes tomava a inciativa de escolher músicas e ir à frente das coreografias. Além das atividades citadas, uma vez por semana as professoras apresentavam uma história, que podia ser contada através de fantoches, materiais diversos ou dramatizações. Essa apresentação era organizada pela professora Alice e pela outra professora do $1^{\circ}$ ano, que contavam com a ajuda das professoras das outras turmas nos momentos de dramatização. As histórias escolhidas eram aquelas que seriam utilizadas no projeto das professoras do $1^{\circ}$ ano.

- Disposição dos alunos na sala: após a acolhida no pátio a professora Alice levava os alunos ao banheiro e bebedouro e em seguida iam para a sala de aula. Os alunos eram dispostos em grupos com 4 ou 5 crianças. Algumas vezes eles sentavam aleatoriamente e outras a professora mudava alguns alunos de lugar de acordo com os objetivos das atividades do dia. Os grupos de carteiras eram dispostos do meio para o fundo da sala, possibilitando que o espaço em frente ao quadro fique liberado para que os alunos se sentassem no chão no momento da "rodinha". 
- "Rodinha" ou "montinho": ao chegar à sala de aula os alunos normalmente guardavam a pasta (quando havia dever de casa) e sentavam nos grupos aguardando a organização da professora. Em seguida, ela os chamava para a frente da sala, onde eles sentavam no chão. Dependendo do objetivo e da atividade a ser desenvolvida os alunos podiam se sentar em semicírculo, o que eles chamavam de "rodinha", ou podiam se sentar dispostos de maneira mais livre, desde que não atrapalhassem os colegas, o que eles chamavam de "montinho". Interessante destacar que desde o início do ano essa diferença entre "rodinha" e "montinho" já ficou bem clara e os alunos já iam se organizando sem precisar de muito direcionamento da professora. Neste momento eram realizadas diversas atividades: rodas de conversa livres, para possibilitar que os alunos contassem suas experiências; rodas de conversa direcionadas, sobre um determinado tema em questão; explorações diversas no quadro: calendário, tempo, letras, números, alfabeto, contagem de alunos, relação número-quantidade, etc.; contagem e recontagem de histórias; conversas sobre o dever de casa; socialização de atividades realizadas durante o dia; dentre outras. É importante salientar que esse momento não se restringia apenas ao início da aula, como uma preparação para a atividade seguinte, mas constituia atividades bases do dia, inclusive alternando situações em que os alunos se sentavam nas carteiras em grupo e em que voltavam para a rodinha em outras partes do dia.

- Projeto "Contando histórias, formando leitores": era um dos projetos que direcionava o trabalho pedagógico com as turmas do $1^{\circ}$ ano. Elaborados pelas professoras, o projeto consistia em incentivar a formação de leitores a partir da contação de histórias. Além disso, era a partir das histórias que todos os conteúdos curriculares eram organizados de modo que fossem apresentados de maneira contextualizada a partir de um determinado tema. Como já foi dito, a história era inicialmente apresentada no pátio, a partir de recursos diversos, no momento da acolhida. Em seguida, a professora Alice realiza atividades mais direcionadas na sala de aula, que poderiam ser: recontagem da história com apoio do livro; recontagem da história pelos alunos; rodas de conversa sobre a história; produções artísticas, tais como: desenho, pintura, confecção de fantoches com os personagens, dobraduras, dentre outras; atividades de sistematização do sistema de escrita alfabética, tais como: lista de palavras da história, jogos, cartazes, registros escritos, etc; votação do personagem favorito e confecção de gráfico, dentre tantas outras possibilidades. Essas atividades eram desenvolvidas em vários dias seguidos, compondo assim uma sequência didática a partir da história selecionada. Vale salientar que na primeira semana de aula a professora Alice levou dezenas de livros para que os alunos pudessem olhar, manusear e conversar a respeito para que assim, ela pudesse incluir no 
planejamento os livros que despertaram interesse nos alunos, além dos livros que já haviam sido selecionados previamente.

- Projeto "Gente tem nome e sobrenome": o objetivo do projeto era trabalhar a identidade dos alunos a partir de seus nomes e suas histórias de vida. Além disso, a partir do nome de cada aluno eram trabalhados os conteúdos mais operacionais relativos à aprendizagem de leitura e escrita. A cada semana o foco era em um ou dois alunos e várias atividades eram desenvolvidas a partir deles. Inicialmente, a turma precisava descobrir quem eram os "nomes do dia" e a professora Alice utilizava diversas estratégias de brincadeiras e jogos para esse momento, como: jogo da forca, objetos que lembravam a criança, caixa mágica com objetos que começavam com a mesma letra do nome da criança, foto dos alunos escondida, etc. Este momento gerava bastante curiosidade nos alunos e expectativa em serem os próximos sorteados. Após a descoberta os alunos escolhidos eram entrevistados pelos colegas. Não havia um roteiro pré-definido, sendo que as crianças podiam fazer qualquer pergunta com o objetivo de conhecer melhor aquele aluno. Em seguida eram feitas atividades escritas diversas com os nomes, além da confecção coletiva de um cartaz representado um retrato daquelas crianças, onde todos os colegas participam da elaboração. Ao final, os cartazes eram expostos nas paredes da sala de aula. Além disso, a cada semana todos os alunos levavam um dever de casa para ser realizado juntamente com os pais ou responsáveis sobre temas relacionados à identidade, como: motivo da escolha do nome, dia do nascimento da criança, organização e hábitos familiares, principais experiências na primeira infância, gostos e interesses, etc. Quando os alunos retornavam com o dever de casa, as informações eram compartilhadas com o restante da turma, onde cada criança tinha a oportunidade de contar sobre o que conversou com a família sobre aquele tema.

- Brincadeiras: todos os dias, geralmente ao final da aula, a turma tinha um momento destinado a brincadeiras, que podia ser no parque, na quadra ou com o trabalho diversificado com brinquedos. No dia da quadra a professora Alice revezava momentos de brincadeiras livres e momentos de brincadeiras ou jogos direcionados, onde trabalhava aspectos da psicomotricidade. O trabalho diversificado com brinquedos, que os alunos chamavam de "grupinhos", foi um momento criado pela professora para que os alunos tivessem a possibilidade de brincar com determinados tipos de materiais já selecionados e era realizado duas vezes por semana. Esse momento era inicialmente composto por cinco grupos: massinha; miniaturas; faz de conta; construção; lego. Com o tempo, a professora incluiu o quadro negro 
por perceber o interesse dos alunos em utilizar também esse recurso. Nos dias destinados ao trabalho diversificado os alunos eram direcionados para um determinado grupo de brincadeiras, sendo que às vezes eles escolhiam o grupo que queriam participar e outras vezes eram realizados sorteios. Dessa forma, todas as crianças passavam por todos os grupos de brincadeiras, possibilitando a interação com materiais diversos, que muitas vezes as crianças não escolhiam e, por isso, não tinham a oportunidade de descobrir outras formas de brincar. Ademais, esse momento se tornava uma ocasião favorável para que as crianças interagissem com todos os colegas da sala, já que a formação dos grupos não era fixa.

- Educação estética: ao final da semana, às sextas-feiras, era reservado um momento da aula destinado à educação estética. Geralmente, esse momento era composto por dois tipos de atividades em semanas alternadas: artes e culinária. Nas aulas de artes a turma trabalhava com desenho, pintura, dobraduras, confecção de fantoches e de brinquedos, dentre outras atividades. Nas aulas de culinária a turma preparava uma receita, com a participação de todos os alunos. As crianças chamavam esse momento de "aula de comidinha" e se mostravam bastante participativas e animadas, inclusive sugerindo as próximas receitas a serem realizadas. As receitas realizadas normalmente tinham relação com a história que estava sendo trabalhada na semana, por exemplo, na história "O lobo vegetariano" a turma fez uma receita de espetinho de salada de frutas, já a partir do livro "Branca de Neve e os sete anões" eles fizeram uma receita de maçã do amor. Essa contextualização também ocorria com as atividades artísticas.

É importante salientar que as atividades descritas não possuíam uma estrutura rígida no planejamento da professora Alice, sendo que alguns aspectos destacados em determinadas atividades eram também encontrados em outros momentos da rotina da turma. As rodas de conversa, por exemplo, não se restringiam aos momentos da "rodinha", bem como as atividades artísticas não estavam concentradas apenas em um dia da semana, integrando também outras propostas de atividades. Tal organização foi realizada apenas para nortear o trabalho pedagógico, entretanto havia uma flexibilização para mudanças e adaptações de acordo com as necessidades da turma ou sugestões dos alunos.

Tendo conhecido melhor o contexto social da pesquisa, apresentamos a seguir a construção teórica conforme tópicos já destacados anteriormente e organizados no texto da seguinte forma: 


\section{Quadro 1 - Organização temática da construção interpretativa da pesquisa}

\begin{tabular}{|l|}
\hline I- Bases que constituem a relação professora-alunos \\
\hline - Clima da sala de aula; \\
- Concepções da professora sobre o processo de aprendizagem; \\
- Encantamento com a infância; \\
- Alunos como sujeitos protagonistas de seus processos de aprendizagem e desenvolvimento; \\
- Individualização da relação/olhar para o sujeito; \\
- Importância da imaginação e emoção no desenvolvimento infantil; \\
- Envolvimento emocional como base das relações; \\
- Comunicação com os pais. \\
\hline 2- Aspectos da constituição subjetiva da professora Alice e sua articulação para a \\
compreensão das relações construídas com os alunos. \\
\hline 3- Síntese integrativa dos aspectos analisados: respondendo aos objetivos da pesquisa. \\
\hline
\end{tabular}

\subsection{Bases que constituem a relação professora-alunos}

\section{Clima da sala de aula}

A minha aproximação com a turma começou logo no início do ano letivo, mais precisamente na segunda semana de aula. Dessa forma, os alunos ainda estavam num período de adaptação com a nova rotina e com a nova professora. Apesar disso, já havia uma organização bem clara na sala de aula, que demonstrava a construção de uma dinâmica que se foi consolidando com o tempo.

Logo nos primeiros contatos com a turma ficou claro que a sequência de atividades das aulas era bem organizada, apesar de não ser rígida. A professora constantemente explicava essa sequência para os alunos e sempre que necessário fazia esclarecimentos e dava orientações. Percebemos que nas primeiras semanas as orientações da professora para os alunos eram mais recorrentes e, com o passar do tempo, estas foram se tornando desnecessárias. Por exemplo, quando os alunos terminavam de lanchar ela os orientava a organizar os pratos e talheres vazios em uma única mesa e quem ia terminando já podia ir ao banheiro. Frases como "quando sair usa o banheiro, escova os dentes e não esqueçam de tomar água" ajudavam os alunos a se programar para aquele momento que ficariam fora da sala de aula. A professora, por sua vez, ficava na porta observando tanto os alunos que estavam na sala como os alunos que haviam ido 
ao banheiro. As orientações eram claras e objetivas, e a professora Alice as repetia sempre que necessário, com tom de voz que demonstrava paciência. Esse tipo de postura era observado também nas explicações das atividades e nos momentos de dúvidas dos alunos.

Momentos que poderiam desestabilizar a organização da sala eram tratados com naturalidade pela professora que, novamente, dava orientações na busca da solução de problemas. Um exemplo desse tipo de situação foi quando um aluno derramou iogurte em sua mesa e no chão ao final do horário do lanche. As outras crianças gritaram acusando-o e ele ficou imóvel, com um olhar de preocupação e rosto apreensivo. Parecia que as crianças esperavam que ele fosse levar uma bronca, pois os outros alunos olhavam para a professora aguardando a reação dela enquanto o que havia derramado o iogurte demonstrava aflição. A professora, no entanto, manteve-se no mesmo local em que estava e com o tom de voz calmo falou: "tá tudo bem, vai lá na sala dos servidores e pede um pano pra limpar a mesa." O aluno seguiu a orientação e os outros continuaram o que estavam fazendo.

Apesar de simples, este episódio exemplifica uma postura da professora que tem implicações no clima que vai se estabelecendo na sala de aula. Em nossa experiência profissional, já observamos turmas em que os alunos estão sempre tensos por saberem que qualquer situação adversa pode ser motivo de bronca ou exposição. Nesta turma, no entanto, as situações inesperadas eram tratadas com naturalidade pela professora e, com o tempo, também pelos alunos. Observamos, por exemplo, momentos posteriores em que ocorreram episódios parecidos e que os próprios alunos já tomavam a iniciativa de ir buscar o pano, apenas avisando o motivo de estarem saindo da sala.

Outra estratégia utilizada pela professora era sempre explicar o porquê de determinado comportamento esperado dos alunos. Nos momentos de história, por exemplo, quando os alunos estavam sentados na rodinha e começavam a se agitar, ela dizia: "senta, porque senão o colega que tá atrás de você não vai conseguir ver o livro" ou "calma, agora é a vez do seu colega falar, tem que esperar". O que queremos destacar com esses exemplos é que as intervenções da professora em relação ao comportamento dos alunos não era apenas uma "ordem" ou algo arbitrário, mas eram feitas no sentido de manter uma organização que garantisse o bem estar de todos e que os próprios alunos compreendessem o motivo de se comportarem de determinada maneira.

Sobre essa organização da turma, a professora esclareceu que na primeira semana de aula houve um momento para a discussão dos combinados entre eles:

Teve um momento, a gente sentou na rodinha e aí a gente começou a conversar em cima de uma história que a gente tinha apresentado no pátio. E aí a gente começou a falar né, sobre assim o que seria necessário pra que todo mundo convivesse bem, 
mais harmoniosamente possível e aí eles foram colocando. Aí foi engraçado porque a maioria das coisas não fui eu que coloquei, partiram deles mesmo, essa questão do bater eles colocaram muito, essa questão da conversa. [...] Eles foram colocando as necessidades deles, como eles gostariam de ser tratados, como eles queriam que fosse essa nossa relação em sala de aula. (Entrevista)

Em pouco tempo os alunos foram compreendendo essa dinâmica e já realizavam as posturas acordadas sem que fosse necessária a intervenção da professora. Era como se houvesse um contrato implícito entre eles, sem que fosse preciso ficar lembrando como deveriam agir. Até mesmo quando a professora precisava sair da sala os alunos mantinham os mesmos comportamentos de quando ela estava presente. Entendemos que esse tipo de atitude era facilitado pelo clima de liberdade que havia na sala de aula, pois a naturalidade com que a professora agia nos momentos de conflitos e negociações favorecia com que os alunos não se sentissem cerceados nem avaliados constantemente. Outro trecho da entrevista ilustra esse aspecto:

A gente tem os combinados assim que eu já falei pra eles "olha, eu não sou mãe, eu não sou pai, a gente vai estabelecer uma relação aqui de respeito, respeito vocês $e$ vocês me respeitam, a gente pode conversar sobre tudo, vocês não tem que ter medo de ninguém, vocês não tem que ficar sentados o tempo todo...” Por que assim eu acho que é bem essa questão do respeito à infância mesmo e eu tento deixar isso claro pra eles da mesma forma que eu deixei pras famílias na primeira reunião. Então assim, como é que eu vou podar o movimento da criança? Como é que eu vou podar a expressão oral, corporal delas? Então assim, eu tento sempre tá mediando ali através do diálogo, mas sem pedir que elas neguem a identidade delas, acho que é bem por aí mesmo. (Entrevista)

\section{O respeito entre os pares e o respeito às características próprias da infância estavam}

na base das relações que foram se construindo entre a professora Alice e seus alunos. Essas características implicavam num clima de liberdade e de aceitação na sala de aula, em que os alunos se sentiam à vontade para falar e agir de maneira espontânea.

Quando havia situações de conflito, que atrapalhavam o desenvolvimento das atividades, a professora sempre recorria ao diálogo com os alunos, relembrando os combinados e tentando fazer com que eles se sentissem corresponsáveis pela organização da sala de aula. Nestes momentos ela apresentava firmeza, demonstrava sua insatisfação com aquele determinado tipo de comportamento, mas não recorria a gritos e ameaças, pelo contrário, fazia questão de explicar o motivo de aquele comportamento ser inadequado que, no caso acima, se referia ao fato de a conversa paralela atrapalhar o colega que estava apresentando.

A utilização do diálogo como meio de negociação nos momentos de conflitos também foi percebida em diversas situações. Um exemplo disso foi quando a professora estava fazendo o acompanhamento individualizado em sua mesa com um aluno enquanto o restante da turma terminava um desenho. Como de costume os alunos estavam sentados em grupos com quatro 
crianças. Um desses grupos estava conversando muito alto, de modo que deixavam de fazer a atividade e atrapalhavam os outros colegas. Apesar de chamar a atenção do grupo várias vezes e pedir que eles falassem mais baixo e se concentrassem no dever, as orientações não surtiram efeito. Então a professora avisou: “quando bater o sinal (do recreio) o grupo vai ficar aqui pra gente conversar". Quando o sinal do recreio tocou os alunos do grupo se dirigiram à mesa dela enquanto os outros saíram da sala.

Professora: o que é o nosso combinado?

Lia, Ruan, Beatriz e Tiago ${ }^{10}$ permaneceram em silêncio.

Professora: Precisa ficar o tempo todo sem conversar na sala?

Alunos: Não.

Professora: Mas tem que falar como?

Alunos: Baixo.

Professora: e eu to falando e vocês não tão ouvindo. Eu chamei a atenção de vocês várias vezes...

Ruan: cinco vezes.

Professora: Pois é! Deu até pra contar, né. E aí, como vamos resolver?

Os alunos ficam em silêncio pensativos.

Tiago (depois de pensar um pouco): a gente pode conversar e combinar.

Professora: Mas só falar parece que não tá resolvendo.

Tiago: mas agora a gente vai falar baixo.

Professora: Posso confiar em vocês?

Os alunos balançam a cabeça indicando que sim.

Professora: Posso confiar em você, Lia?

Lia: pode.

Professora: Posso, Ruan?

Ruan: sim.

Professora: Posso, Tiago?

Tiago balança a cabeça que sim.

Professora: Posso, Beatriz?

Beatriz balança a cabeça que sim.

Professora: tudo bem. Podem ir brincar.

Essa postura de conversar com os alunos no início do recreio já havia sido observada em outras situações. Entendemos que essa atitude não se apresentava como uma punição, mas como uma forma de a professora poder ter uma conversa mais reservada com um aluno ou um grupo de alunos. Além disso, ela sempre dividia o problema com as crianças, esperando que elas mesmas apresentassem alguma solução. O tom de voz utilizado, a expressão facial, o fato de ficarem sozinhos na sala, tudo que envolvia a situação indicava que era um momento mais sério, entretanto não havia constrangimentos para os alunos. Inclusive as crianças já sabiam que depois da conversa poderiam brincar normalmente no recreio. Este fato foi percebido quando notamos que nesses momentos em que a professora conversava com um aluno ou um grupo de alunos na hora do recreio outras crianças, colegas daqueles que estavam na sala, ficavam no pátio, próximo à porta da sala de aula, esperando a conversa terminar para eles poderem ir brincar, ou seja, eles já sabiam que haveria apenas uma conversa e não um "castigo".

\footnotetext{
${ }^{10}$ Foram utilizados nomes fictícios para preservar a identidade dos alunos.
} 
Quando perguntava para os alunos "posso confiar em você?" a professora não fazia a pergunta apenas para o grupo, mas para cada criança em específico, olhando para cada uma delas e aguardando sua resposta. Entendemos que essa postura era realizada no sentido de firmar um compromisso com cada criança, para que cada uma entendesse que tem parte de responsabilidade naquele acordo que deveria cumprido. Nos momentos de observações não percebemos decisões arbitrárias da professora nas situações de conflito, sempre havia uma conversa com os envolvidos e as orientações da docente eram feitas no sentido de alertar para o comportamento inadequado e não no sentido de gerar punições ou ameaças. Compreendemos que dessa maneira a professora e os alunos formavam um grupo em que havia compromisso e responsabilidade mútuos, em que todos precisavam fazer sua parte para o bom andamento das aulas.

Outro ponto que merece destaque é que a professora Alice não apenas cobrava que os alunos respeitassem os combinados, mas buscava também cumprir com os acordos realizados. Por várias vezes observamos situações em que ela parava uma atividade sistematizada, mesmo quando ela não havia sido concluída, por que era o horário de brincadeira dos alunos. Em um dia específico ela comentou: "vamos parar e continuar amanhã senão a gente vai perder o tempo de ir pros grupinhos, e aí vocês vão reclamar com razão, né?!'” Dessa forma, os acordos não eram relativizados e a professora buscava respeitar os combinados estabelecidos, especialmente quando se tratava dos direitos das crianças. A organização e andamento da turma era marcada por esse compromisso e respeito mútuos.

De acordo com Tacca (2006, p. 64) "professor e alunos devem compor um espaço relacional em que fique criada uma atmosfera de compromisso e responsabilidade na consecução dos objetivos educativos". Neste contexto, os processos comunicativos têm fundamental relevância para a construção de uma confiança mútua que fortaleça o cumprimento dos acordos firmados. Destacamos, ainda, que que a professora Alice buscava construir uma "relação de confiança" com os alunos, conforme foi destacado por McDermott (1977). Para o autor, a relação entre professores e crianças é central na organização do tempo e do trabalho na sala de aula, e os processos comunicativos não podem se limitar a coerções e ações diretivas dos professores.

Além de utilizar o diálogo como meio de resolver conflitos a professora incentivava que os alunos fizessem o mesmo. Uma situação observada na quadra de esportes ilustra essa questão. Vários alunos já haviam reclamado que Daniel estava batendo nos colegas. Em uma dessas reclamações, a professora foi mais firme: "Daniel, se você não parar de bater vai acabar perdendo o direito de brincar." Ele explicou que estava jogando futebol e os outros meninos 
estavam atrapalhando o jogo dele, passando toda hora em frente ao gol. Ao passo que a professora orientou: "então vai lá e conversa com eles." A partir desse momento, notamos que Daniel começou, timidamente, a falar com os colegas que estavam atrapalhando, pedindo que dessem licença. Como alguns alunos demoravam a atender o pedido de Daniel, a professora alertou: "lá é o lugar da bola, se vocês ficarem passando toda hora vão acabar sendo acertados pela bola mesmo".

Daniel era um aluno com quem nem sempre a professora conseguia estabelecer um diálogo, pois muitas vezes quando ela o chamava para conversar ele fechava a cara, apresentando uma expressão facial contrariada, cruzava os braços e não falava nada, apenas escutava. Entretanto, na situação relatada percebe-se que ao correr o risco de perder o direito de brincar o aluno prontamente se defendeu apresentando uma justificativa para aquela atitude. Entendemos que a explicação de Daniel para a professora foi motivada não apenas pelo risco dele ter que parar de brincar, mas por ele estar se sentindo injustiçado, já que os colegas estavam realmente atrapalhando a brincadeira dele. Após a orientação da professora para que ele resolvesse conversando, percebemos uma tentativa neste sentido, que para este aluno já representa um avanço. Ao alertar os outros alunos para que não ocupassem o lugar destinado à bola a professora demonstrava reconhecer esse avanço na postura do Daniel e fez a intervenção para evitar que outras situações de conflito ocorressem entre aqueles alunos. Apesar de incentivar que os alunos resolvessem esse tipo de conflito de maneira independente e através do diálogo, a professora valorizava a tentativa de Daniel e tratava de evitar novas situações desagradáveis que fizessem o aluno voltar a sentir injustiçado.

Em alguns momentos de conflitos a professora apresentava uma postura provocadora na tentativa de gerar possibilidades de reflexões nos alunos, como podemos observar no episódio seguinte:

Tiago: ô tia, ele tá me chamando de egoísta. Professora: por que ele tá dizendo isso? Você tá deixando ele brincar com você? Tiago: Nâo!

Professora: Então será que você não tá sendo egoísta? Pensa bem. Eu acho que você sempre brinca com os mesmos colegas, talvez você devesse tentar brincar com outros pra ver como é.

A intervenção da professora sinalizava para uma tentativa de Tiago rever suas posturas e só foi possível porque ela já tinha uma proximidade com o aluno a respeito de algumas de suas características pessoais.

No espaço da sala de aula foi-se criando um ambiente acolhedor, em que todos tinham a oportunidade de se expressar e a professora estava sempre questionando e provocando para proporcionar ainda mais expressões dos alunos. Esse ambiente acolhedor podia ser notado não 
apenas pela turma, mas por aqueles que, por algum motivo, participavam daquele espaço em determinado momento, como nas atividades realizadas em parceria com outros professores. $\mathrm{O}$ clima acolhedor também foi vivenciado por mim que, em pouco tempo de presença na sala de aula, já me sentia parte daquele espaço social devido à receptividade da professora e dos próprios alunos. Com o tempo, as crianças também passaram a me procurar para contar suas experiências fora da escola e durante as atividades, mesmo que as vezes eu não perguntasse, elas me explicavam o que estavam fazendo, contavam o que tinham realizado nos dias em que eu não estava presente e me convidavam para participar das próximas atividades festivas. Além disso, sempre demonstravam interesse pelas minhas anotações e pelos meus estudos fazendo questionamentos diversos, tais como: "o que você tá escrevendo?”, "por que você precisa escrever isso?", "quando você sai da escola pra onde você vai?", "você não veio ontem por que tava estudando?”, “hoje tem pesquisa?”, etc.

A partir dessas interpretações iniciais surgiram algumas questões: por que a professora se posicionava dessa forma? O que estava na base desse tipo de relação que foi sendo construída na sala de aula e que era muito marcada pelo modo como a professora desenvolvia o trabalho pedagógico? Que outros aspectos constituíam a relação entre professora e alunos e como isso implicava um tipo de funcionamento daquele espaço social?

Para responder essas questões e aprofundar a análise daquele espaço relacional elencamos a seguir alguns aspectos que acreditamos estar na base da relação entre a professora e os alunos na sala de aula. Salientamos que esse tipo de organização se faz necessária para a compreensão da nossa construção-interpretativa, entretanto cada aspecto destacado não deve ser percebido de maneira isolada, visto que eles se articulam de maneira complexa na constituição da relação.

Concepção da professora sobre o processo de aprendizagem

Para a professora Alice todos os momentos durante a aula poderiam ser ricas oportunidades de aprendizagem. O desenvolvimento da oralidade a partir dos diálogos com as crianças era uma constante na sala de aula, sendo que a sistematização através dos registros escritos em folhas ou cadernos não era considerado o aspecto mais relevante. Por ser o primeiro ano do Bloco Inicial de Alfabetização, percebemos na prática de muitos professores alfabetizadores uma supervalorização dos momentos de registro escrito das crianças em detrimento de outras atividades com o corpo e até mesmo de elaboração de pensamento. A professora Alice, no entanto, criticava essa tendência e buscava uma prática diferenciada nesse 
aspecto. Essa crítica ficou clara desde o início do ano quando os próprios alunos começaram a cobrar "tarefas" ou "deveres", se referindo a atividades de registro fotocopiadas.

A questão de tarefa, então assim, eles me cobravam o tempo todo por que eles falavam: "que horas que a gente vai fazer tarefa?", "tia a gente veio pra escola hoje e não fez nenhuma tarefa". Então assim, a gente trabalhava com dobradura, a gente trabalhava com massinha, a gente trabalhava com esses materiais mais concretos, mas pra eles só tinha tarefa se eles tivessem escrevendo. (Entrevista)

Para a professora Alice, essa atitude dos alunos se explicava pelo fato de no ano anterior, o trabalho pedagógico ser direcionado pela predominância de atividades escritas e reprodutivistas, mesmo estando em uma turma de Educação Infantil. Essa não era uma crítica apenas da professora Alice, mas também da professora da outra turma de $1^{\circ}$ ano. No início do ano, nos momentos de coordenação pedagógica, era comum as conversas entre as professoras sobre esta situação, onde elas percebiam que os alunos eram capazes de copiar do quadro, entretanto não conseguiam se organizar nos momentos de brincadeiras e nos momentos de rodinha, por exemplo. A crítica era feita ao tipo de trabalho pedagógico que estava sendo desenvolvido na Educação Infantil e que não correspondia àquilo que era adequado para este nível de ensino, e foi relatada pela professora Alice no momento do Conselho de Classe para possibilitar a discussão do tema.

Então assim foi uma coisa que eu senti muita dificuldade, acho que Eliane também, que eles sempre cobravam isso, escrever, escrever, escrever e questão de vídeo por vídeo também, que eles queriam assistir televisão todos os dias. Então acho assim, que tem umas coisas que a gente enquanto grupo... um vai seguir pro outro... a gente tem que repensar pra tá trabalhando. E eu acho que essa discussão da educação infantil, esse respeito aos documentos que a gente tem, ele tem que começar a ser abordado também no chão da escola. (Conselho de Classe $1^{\circ}$ bimestre)

A preocupação da professora Alice não era apenas com seus alunos naquele ano e naquele momento específico, mas a discussão coletiva para a construção de uma prática na Educação Infantil mais condizente com os documentos oficiais e com o desenvolvimento dos alunos de maneira integral. Esse tipo de discussão era recorrente nos momentos de coordenação pedagógica e nos conselhos de classe. Apesar disso, essa situação não se apresentava como um aspecto dificultador para a professora Alice, que fazia questão de explicar aos alunos que aprender ia muito além de escrever.

Teve uma hora que eu sentei com eles e eu conversei, falei: "gente, tarefa não é só você pegar o lápis, você tá escrevendo, não, isso aqui também é uma forma de tarefa. Olha, vamos ver o que a gente já aprendeu hoje... " Então assim, eu deixei isso claro pra eles também e foi engraçado que eles foram falando: "não tia, a gente aprendeu isso, aprendeu aquilo". Eu falei: "Pois é, e aí, a gente precisou escrever o tempo todo pra aprender isso? A gente não precisou. É...eu já sei que vocês sabem fazer o traçado das letras, não preciso que vocês escrevam pra mim dez, vinte vezes o traçado." (Entrevista) 
Com o passar do tempo, os alunos foram compreendendo a dinâmica das aulas e a diversidade de estratégias que eram propostas pela professora, de modo que essa cobrança por "tarefa" desapareceu. Em vez de dizer "a gente não vai fazer tarefa?”, os alunos passaram a questionar "o que a gente vai fazer hoje?". Essa pergunta era comum no início da aula e a professora Alice sempre respondia, as vezes apresentando de maneira resumida o planejamento do dia, outras vezes instigando a curiosidade das crianças de acordo com o objetivo das próximas atividades. Em outras vezes, no momento da rodinha, a professora pedia para os alunos irem relembrando o que foi realizado naquela semana ou nos dias anteriores. Dessa forma, eles iam organizando as atividades numa sequência lógica e se conscientizando do que tinham aprendido naquele período. Compreendemos que essas constantes discussões abriram espaço para a produção de novos sentidos subjetivos sobre o que é aprender, em que os alunos puderam ampliar a concepção anterior reducionista de que aprendizagem estava associada apenas às tarefas escritas.

A professora destacava ainda, que considerava mais relevante a construção das ideias e de pensamento do que a memorização:

Tento tornar esse momento que eu tenho com eles mais leve, um momento mais alegre, que não seja penoso, que eles não sejam punidos, e por eu acreditar que eles tão aqui pra desenvolver essa questão do raciocínio e não do treino. (Entrevista)

Os indicadores apontam que a professora Alice compreende a aprendizagem como um processo de construção, que vai além da sistematização escrita do conhecimento.

Os trechos a seguir, retirados do complemento de frases, fortalecem essa interpretação:

62- Aprender necessidade de transformação.

65- As pessoas construção.

20- A sala de aula um espaço de vivência.

Para a professora Alice, as atividades não se reduziam às folhas para registro escrito e os momentos vivenciados na sala de aula na diversidade de estratégias propostas eram fundamentais para a aprendizagem dos alunos.

Naquela sala de aula ficava claro o espaço que era dedicado às expressões dos alunos nas mais diversas situações: na rodinha quando eles dividiam suas experiências fora da escola, nas rodas de conversa após as histórias que foram contadas, na apresentação das atividades de registro ou até mesmo durante a realização das atividades, que não possuíam uma estrutura rígida. Entendemos que esse tempo e espaço dedicado à expressão dos alunos não tinha o objetivo apenas de desenvolver a oralidade, mas de permitir que as crianças expressassem suas opiniões e pensamentos e, assim, as possibilidades de aprendizagem perpassavam todas as atividades propostas. Sobre esse aspecto a professora Alice comenta: 
Eu valorizo muito assim essa questão da relação dialógica, porque eu acredito assim nas rodas de conversa, nos momentos que a gente tá ali fazendo essas trocas a gente tá aprendendo e... a maioria das coisas você tá ali naquela interação você percebe que a criança sabe, então...é....eu não vejo essa necessidade de tá sistematizando o tempo todo. Acho que essa aprendizagem ela acontece mais nesse campo oral do que no registro. E mesmo porque se eu for pro registro, eu vou ter que voltar pra oralidade, porque eu não vou poder... é... fazer inferências sobre aquilo que as crianças registraram se elas não disserem pra mim o que tá ali. Então assim é sempre esse vai e volta, mas eu valorizo muito a questão da oralidade. (Entrevista)

Esse "vai e volta" que a professora se refere era constante nas aulas. Sempre após a finalização de uma atividade escrita ela pedia que o aluno explicasse o que ele fez, escreveu ou desenhou. Dessa forma, ela poderia compreender a produção da criança, conhecendo o percurso que ela percorreu ao realizar a atividade, e não somente o produto. Além disso, muitas dessas produções eram apresentadas para os colegas, onde todos os alunos tinham oportunidade de participar. A situação a seguir ilustra esse aspecto.

Os alunos sentaram no chão em semicírculo, o que eles chamam de rodinha, e a professora sentou na frente numa cadeira baixa, de modo que todos os alunos a vissem. No quadro havia um cartaz colado com a frase "De onde vem os bebês?". A professora foi chamando de um por um para se levantar, mostrar o desenho e falar sobre ele. Este foi um momento em que houve a participação de todas as crianças, sem exceção, pois havia uma intencionalidade da professora em entender a produção dos alunos, além de desenvolver a oralidade. Nos momentos de rodas de conversas livres ou até mesmo dirigidas percebemos que algumas crianças falavam bastante, queriam sempre expor algo, enquanto outros alunos que apresentavam postura mais tímida participavam apenas observando, preferindo ficar calado. Dessa forma, o momento de expor o trabalho e falar sobre ele apresenta-se como uma possibilidade para essas crianças mais reservadas desenvolverem a habilidade de falar em público e, ainda, da professora se aproximar mais das opiniões e pensamentos desses alunos. Apesar de identificarmos essa postura mais reservada em alguns alunos, nas observações realizadas nunca houve recusa por parte deles em apresentar seus trabalhos.

Os alunos mostravam o desenho respondendo a pergunta "De onde vem os bebês?" e a professora instigava a reflexão a partir de questionamentos. Em seguida, eles mesmos colavam no cartaz que estava fixado no quadro. Os questionamentos da professora geravam explicações diversas, como pode ser observado nos trechos seguintes:

Professora: de onde vem os bebês?

Adriano: da barriga.

Professora: e como ele foi parar lá?

Adriano (pensa um pouco em silêncio): ele sai e não volta mais.

Professora: de onde vem os bebês?

Bento: da barriga. 
Professora (coloca as mãos na cintura e pergunta com tom investigativo): e como ele foi parar lá?

Bento: foi Deus que colocou.

Carine: Deus coloca o ovo, o ovo cresce e aí vira o bebê.

Professora: de onde vem os bebês?

Diogo: do coração?

Professora: do coração? E o que cresceu foi a barriga ou o coração?

Diogo: o coração!

Professora: então tá!

O objetivo da professora era entender o que as crianças pensavam sobre esse tema, por isso ela fazia perguntas que permitiam ir além daquilo que estava desenhado, entretanto não interferia dando a informação correta, pois isso seria feito no dia seguinte com a apresentação de um vídeo. Quando o aluno ia à frente a professora o envolvia colocando o braço em sua cintura, pegava o desenho e levantava para todos verem e olhava diretamente para a criança enquanto ela estava falando. Alguns alunos sentavam no colo dela ou passavam o braço em seu pescoço descansando descontraidamente. Enquanto isso os colegas faziam elogios, comentavam e prestavam atenção.

Continuando com as apresentações dos desenhos pelas crianças, uma explicação interessante foi a de Fernando que fez o seguinte desenho:

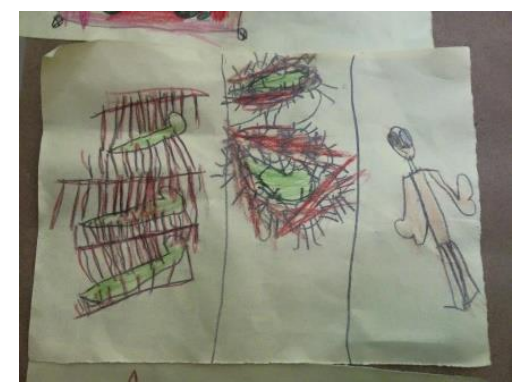

Fotografia do desenho do aluno Fernando, em resposta à questão "De onde vêm os bebês?"

Professora: vamos prestar atenção aqui no desenho do Fernando, tá bem legal.

Fernando (apontando o primeiro desenho): esses aqui vem caminhando, entra na barriga e vira o bebê.

Professora (apontando para o desenho): e o que são esses aqui?

Fernando: micodômetos.

Professora (sorrindo): como é?

Fernando: são os micodômetos. Eles tavam pequeno (junta o polegar com o indicador tentando representar algo bem pequeno) ai eles caminham e vira bebê.

Professora: ah, são os espermatozoides?

Fernando balança a cabeça que sim.

A professora elogia o desenho, pede que as outras crianças prestem atenção na explicação do colega e repete o que ele falou, depois pergunta para Fernando:

Professora: e de onde eles vem?

Fernando (passando a mão na barriga da professora): daqui!

Professora: então tá, pode colar lá. Ficou muito bonito.

O aluno colou o desenho no cartaz, depois saiu da rodinha, foi até o lugar onde eu estava sentada observando e disse: "viu, tia, meu negócio lá? É muito interessante meu desenho, né?" Eu fiz um elogio e concordei com a afirmação dele, então ele voltou pra rodinha sorrindo com 
um ar de satisfação. Parece que Fernando percebeu que sua fala e desenho traziam informações que ainda não tinham sido discutidas pelos colegas e, nesse sentido, se sentiu importante com a realização da atividade.

Pelo desenho e explicação do aluno a professora entendeu que provavelmente ele estava se referindo aos espermatozoides. Sem lembrar o nome certo, ele utilizou um nome complicado que veio em sua mente, utilizando uma estratégia para resolver seu problema naquele momento. Mesmo sem saber o nome correto e de onde eles vêm, o aluno fez a representação, provavelmente por já ter visto uma imagem ou vídeo a respeito, e já entende que eles participam, de alguma forma, da formação do bebê. Se a professora tivesse apenas recolhido os desenhos, sem dar a oportunidade de os alunos apresentarem, talvez não tivesse alcançado a compreensão do que Fernando estava querendo representar. Entendemos que a professora utiliza os momentos de apresentação dos alunos não apenas como forma deles se expressarem ou desenvolverem a oralidade, mas como uma maneira de conhecer o pensamento das crianças, o que elas já sabem a respeito de determinado assunto, quais suas opiniões e representações, aspectos fundamentais para pensar em novas estratégias e intervenções na organização do trabalho pedagógico. Dessa forma, as ações da professora na busca por conhecer os alunos não se restringiam às atividades sistematizadas ou momentos de avaliação, mas se estendia aos diálogos e a todos os momentos relacionais. Com isso, podia atingir os processos de significação das crianças na aprendizagem.

Esse momento de apresentação dos desenhos ou produções dos alunos foi se tornando parte integrante da rotina das aulas de modo que, como o passar do tempo, mesmo os alunos que demonstravam um comportamento mais introvertido no início do ano, com dificuldade de se expressar, passaram não só a se apresentar com mais facilidade, como também a pedir para ir à frente, mesmo quando a proposta da atividade não exigia que todos os alunos fossem.

A valorização das falas e expressões dos alunos pela professora Alice não se restringia apenas aos momentos formais, mas perpassava todas as situações informais. Nos momentos de brincadeiras, no recreio, ao término de uma atividade ou até mesmo durante a realização dela, sempre que um aluno queria falar algo, fosse relacionado à aula ou fosse sobre suas experiências fora da escola ou, ainda, qualquer outro assunto, a professora Alice parava para escutar, olhava diretamente para o aluno, prestava atenção na sua elaboração e respondia. Nas palavras da professora:

Eu acho muito importante essa questão da escuta sensível, de você parar, de você escutar, de você saber quais são as necessidades pra ela naquele momento. (Entrevista) 
Esse aspecto pôde ser observado em diversos episódios, como o relatado a seguir. Em uma segunda-feira, no início da aula, os alunos estavam bastante agitados. A professora disse que entendia que eles tinham muitas histórias pra contar sobre o final de semana, mas que eles precisavam se acalmar por que eles iriam iniciar uma atividade e a roda de conversa ficaria para mais tarde. Nesse momento, Renato interrompeu, levantou a mão e gritou: "Eu assisti Guerra Civil!" A partir desse momento várias crianças começaram a falar ao mesmo tempo fazendo com que a professora revisse sua decisão. Ela pediu então que eles se levantassem, sentassem na rodinha e passou a organizar os turnos de fala. Os alunos levantavam a mão e ela ia indicando os nomes para organizar a sequência das falas. Surgiram vários assuntos, como mostra o trecho a seguir:

Leandro: Ontem eu assisti Mama.

Professora (com expressão de espanto): Você assistiu Mama? Ai, eu quando assisti fiquei com medo, aquele filme não é pra criança.

Leandro: Mas eu gostei!

Tiago: E eu fui na folia e comprei 100 cartinhas. (segurando um bolo de cartinhas na mão)

Professora; Eu nem fui na folia. Você comprou canjica pra mim?

Tiago: Não! (sorrindo)

Professora: Tá demais, hein! (sorrindo)

Leandro: Eu assisti Anaconda.

Professora: Agora é minha vez, sabe o filme que a tia gosta? De princesa, de contos de fadas, que tem bruxa...

Fernando: cavaleiro...

Professora: isso, cavaleiro. Pois é, e vocês assistindo filme de terror, acho que nós estamos com a idade trocada. Leandro: esse filme tem música de apaixonado.

Professora: e como é música de apaixonado?

Mateus: música lenta.

Ruan: ô tia, eu fico grudado no computador.

Professora (coloca as mãos na cintura com ar investigativo): Tu fica grudado no computador? Fazendo o quê?

Ruan: olhando vídeo de massinha.

Percebe-se que a intenção inicial da professora era que os alunos se acalmassem para ela dar início ao planejamento do dia, entretanto, ao ser interrompida por Renato, que estava ansioso em contar que tinha assistido um filme, e ao perceber a agitação dos outros alunos que também queriam fazer o mesmo e seguir contando suas experiências, ela passa então a organizar os turnos de fala para atender essa necessidade dos alunos naquele momento. A partir das falas citadas, é possível notar que a professora não apenas escuta o que os alunos querem compartilhar, mas dá uma resposta, seja expressando sua opinião a respeito, seja fazendo um novo questionamento para incentivar a continuidade do raciocínio ou até mesmo para entender o pensamento da criança. Destacamos que, ao falar de filmes infantis há ainda uma intenção moral da professora, que, articulado à liberdade de expressão de falas dos alunos, evidencia um processo de contradição presente nas relações.

Direcionar o olhar para cada criança que está falando, fazer um comentário descontraído a seguir, garantir que todos escutem e respeitem o colega, dar sua opinião ou contar algo, mudar 
a entonação de voz, são posturas constantes da professora que observamos nos momentos de rodas de conversa e que indicam a construção de canais comunicativos com os alunos, facilitando uma maior aproximação entre eles. Entendemos que a dinâmica criada nesses momentos, onde as falas dos alunos não são direcionadas para um tema específico, favorece a expressão dos hábitos e experiências fora do contexto da escola, revelando a possibilidade de a professora conhecer mais os alunos para além da sala de aula. Compreendemos que esses momentos de rodas de conversa não servem apenas para os alunos extravasarem e se acalmarem para a próxima atividade, mas favorece a criação de canais comunicativos entre professora e alunos de maneira que haja a compreensão dos sentidos subjetivos e significados entre eles. Os alunos percebem que não estão "falando por falar", parece haver uma preocupação real da professora em ouvi-los e eles se sentem valorizados nesse momento.

Além de organizar a sequência das falas de acordo com quem levanta a mão, a professora utiliza outras estratégias para organizar os turnos de fala e permitir a participação de todos que manifestam interesse, como falas que relembram os combinados: "Se acalma Adriano, agora é a vez do colega, tem que esperar."; "Eu não tô conseguindo ouvir o Fernando"; "Quem já falou agora vai esperar”. Em algumas dessas interferências ela apresenta firmeza no modo de falar na tentativa de garantir a participação de todos e a atenção dos demais alunos à fala do colega.

Essa roda de conversa que, inicialmente, não estava prevista para o dia, durou cerca de meia hora e a professora encerrou dizendo que no decorrer do dia eles poderiam contar outras coisas que tivessem vontade. A situação relatada indica que a professora apresenta uma flexibilidade no planejamento, de modo que possa alterar a sequência das atividades ou mudar o tempo das mesmas para acolher determinada necessidade da turma. Naquele momento, permitir que os alunos contassem suas experiências era mais significativo que seguir para a atividade programada. Compreendemos que esse tipo de decisão, bem como os modos como o momento se desenvolve, fortalece a relação entre a professora e os alunos, possibilitando que eles se sintam valorizados em suas experiências e contribuições. Dessa forma, a comunicação era geradora do desenvolvimento do processo relacional. (TACCA, 2006)

Alguns alunos se sentiam tão à vontade em se expressar que chegavam a fazer comentários que poderiam ser considerados inadequados ou inconvenientes. Em um dia de recreação na quadra, uma aluna comentou que eu estava "mexendo demais no cabelo" e, por isso, "parecia metida". Ao compartilhar essa situação com a professora Alice ela sorriu bastante e comentou: 
É isso que eu mais gosto nas minhas turmas, essa relação, essas tiradas! (Dinâmicas conversacionais)

Outro episódio interessante que representa essa liberdade de expressão dos alunos foi quando a diretora foi até a sala de aula divulgar a rifa de uma bicicleta, que estava sendo realizada em prol da arrecadação de fundos para a festa junina. Na ocasião, a diretora levou a bicicleta para mostrar aos alunos e, quando estava explicando sobre a rifa, foi interrompida por Bento que questionou:

Bento: "ô tia, não deveria ser uma bicicleta de criança?"

A diretora olhou para a professora sorrindo e comentou: "adorei!".

A professora, também sorrindo, disse: "agora explica."

A diretora, então, voltou-se novamente para o aluno e disse:

"Isso mesmo, você tem razão. Mas é que a gente ganhou, foi doação, então não deu pra escolher, mas se você ganhar você pode dar pro papai ou pra mamãe.”

Nesse momento, várias crianças começaram a fazer comentários: “meu pai já tem”, "o meu não”, “ se eu ganhar vou dar pra minha mãe”; e vários alunos levantaram e foram até a diretora fazer perguntas mais específicas.

A presença da diretora na sala de aula poderia causar certo enrijecimento do comportamento pelo papel de autoridade que ela ocupa na instituição escolar e por uma representação hierárquica e controladora que ainda persiste em nossa sociedade e nossas escolas sobre o cargo de direção. Entendemos que essa situação demonstra que os alunos se sentem livres para falar, intervir e questionar. Primeiro, por que essa era uma prática constante na sala de aula e muito incentivada pela professora Alice. Segundo, por que naquele espaço social a diretora também possuía uma aproximação com os alunos, principalmente nos momentos de acolhida no pátio. Mesmo assim, essa era também uma característica da turma da professora Alice, que já era reconhecida na escola como uma turma bastante comunicativa. Certa vez, a diretora comentou que quando tinha que passar nas salas dando algum recado já se preparava, pois sabia que ao passar na turma da professora Alice levaria mais tempo por causa dos questionamentos e comentários dos alunos. No decorrer do ano observamos que até mesmo os alunos que apresentavam comportamentos mais tímidos e silentes, passaram a participar de forma mais ativa e espontânea.

Em nossa concepção, a participação das crianças em diversos momentos ao exporem suas opiniões e posições não pode ser entendida como uma característica fixa da personalidade desses alunos, mas sim por uma produção de sentidos subjetivos que se expressavam no momento da ação, em que o processo relacional, a partir das comunicações verbais e nãoverbais, adquiriam um valor simbólico-emocional de liberdade no funcionamento da turma. 


\section{Encantamento com a infância}

Percebemos em diversos momentos que a professora se divertia com as reações e situações inusitadas dos alunos. Quando alguma criança trazia uma contribuição interessante, inesperada ou engraçada, mesmo que fosse algo não relacionado ao conteúdo que estava sendo trabalhado em sala de aula, a professora demonstrava alegria, sorria e parabenizava o aluno pela contribuição. Durante a coordenação pedagógica eram constantes os momentos em que ela compartilhava com outros professores essas situações inusitadas, inclusive reproduzindo diálogos e demonstrando satisfação com os pensamentos e expressões dos alunos. Essa também era uma prática comum para com a pesquisadora. Todas as vezes que eu chegava à escola, a professora Alice relatava situações que ela considerava interessante e que haviam acontecido nos dias em que eu não estava presente. Eram comum expressões como "você perdeu a atividade de ontem, os meninos amaram!" ou "você não acredita no que o Ruan me disse ontem!'. Algumas vezes, a professora gravava com o celular essas falas dos alunos, inclusive enviando para a pesquisadora.

O clima de liberdade que ia se estabelecendo na sala de aula não era apenas relacionado às falas dos alunos, mas se estendia ao comportamento. Não era exigido às crianças que ficassem sentadas o tempo inteiro, inclusive o planejamento era organizado de modo a incluir o movimento dos alunos. Mesmo naquelas atividades mais formais, que requeriam que os alunos ficassem sentados escrevendo, a professora não se incomodava quando alguns deles levantavam, se movimentavam pela sala, conversavam com os colegas, exceto quando se tornava algo excessivo. Em diversas situações, a professora demonstrava não se incomodar com o comportamento "inquieto" dos alunos. O que para outras pessoas poderia ser visto como bagunça, para a professora Alice era vista como parte do processo de desenvolvimento das crianças daquela faixa etária. Nos momentos coletivos com os outros profissionais da escola, a professora Alice já deixava claro esse posicionamento. Ao apresentar sua turma no Conselho de Classe, ela ressaltou:

"A minha turma é uma turma comum de $1^{\circ}$ ano, que apresenta movimento e comportamento normal pra idade." (Conselho de Classe)

Este aspecto não era algo que ficava apenas no discurso da professora Alice, podendo ser facilmente observado durante as aulas. Mesmo quando precisava interferir para garantir a organização da aula ou impedir que os alunos mais agitados atrapalhassem os outros ela destacava que não esperava um comportamento enrijecido das crianças. Intervenções como "vocês não precisam ficar o tempo todo calados, mas vamos falar mais baixo" ou "não precisa 
fazer fila, mas vamos todos juntos e falando baixinho pra não atrapalhar as outras turmas" eram comuns no dia a dia.

O fato de não apresentar posturas coercitivas quando os alunos estavam se movimentando muito na sala sinaliza que a professora Alice considera que a expressão das crianças não é um aspecto que atrapalhe as aulas, pelo contrário é algo comum, parte do desenvolvimento delas. Esse posicionamento também ficou explícito quando a turma realizou um passeio e uma aluna de outra turma reclamou que, enquanto a professora estava fora do ônibus, organizando o retorno para a escola, os alunos estavam muito agitados.

Aluna: tia Alice, tá uma bagunça lá dentro.

Alice: Ahh, normal, né?! Um monte de criança junta faz bagunça mesmo. Mas pode deixar que já já eu vou lá.

Apesar de ter um planejamento bem organizado e uma sequência lógica das atividades, a estrutura das aulas também não era rígida. Por causa dessa liberdade de expressão e de movimento dos alunos, a sala de aula estava sempre agitada e comunicativa. Quem fizesse uma interpretação apressada poderia considerar que aquele era um ambiente bagunçado, pois havia sempre movimento e barulho. Entretanto, bastava um acompanhamento mais contínuo para compreender que esta situação era na verdade uma "bagunça organizada", em que as atividades iam fluindo naturalmente e os alunos iam se posicionando de acordo com seus ritmos e particularidades.

A composição dos alunos na sala não era uniforme e mesmo quando a agitação das crianças estava muito grande, quando a professora começava a falar eles paravam para prestar atenção. Era como se houvesse um "contrato" entre eles, que fluía naturalmente, sem precisar de controle ou cerceamento.

Quando havia a proposta de realização de uma atividade artística, que usasse recursos materiais diversos, a professora Alice espalhava esses materiais na frente da sala e pedia que os alunos fossem levantando aos poucos para escolher aquilo que eles gostariam de utilizar. $\mathrm{Na}$ nossa experiência profissional, já observamos em outros contextos professores que, nestas oportunidades, passa-se de mesa em mesa entregando os materiais para os alunos, na tentativa de otimizar o tempo e de evitar "bagunça". Entendemos, portanto, que essa postura da professora Alice não era algo aleatório, mas estava vinculada à compreensão de infância que supõe a liberdade dos alunos e o incentivo ao desenvolvimento da autonomia. Nas palavras da professora:

Porque assim eu acho que é bem essa questão do respeito à infância mesmo e eu tento deixar isso claro pra eles da mesma forma que eu deixei pras famílias na primeira reunião. Então assim, como é que eu vou podar o movimento da criança? Como é que eu vou podar a expressão oral, corporal delas? Então assim, eu tento 
sempre tá mediando ali através do diálogo, mas sem pedir que elas neguem a identidade delas. Acho que é bem por aí mesmo. (Entrevista)

Entendemos que essas situações são indicadores de um encantamento da professora com a infância, em que ela valoriza as expressões espontâneas das crianças, as descobertas e aprendizagens para além dos conteúdos formais e não considera a agitação como algo negativo para o desenvolvimento. Dessa forma, não havia por parte da professora uma expectativa de que os alunos se comportassem de maneira padronizada. Alice sempre destacou que sua preferência de atuação é na sala de aula, especialmente com turmas de Educação Infantil ou $1^{\circ}$ ano do Ensino Fundamental. Ao falar sobre essa escolha, ela destacou:

Eu me encontrei mesmo na educação infantil e $1^{\circ}$ ano. $2^{\circ}$ ano já não foi uma experiência assim tão boba, eu já tive uma experiência, mas ainda prefiro educação infantil e $1^{\circ}$ ano. O quê que me encanta? Essa questão da interação entre eles, da espontaneidade, da escuta, do lúdico, das brincadeiras, porque querendo ou não, embora eu acredite que isso tem que permear todo o processo educativo, é...eu acho que na educação infantil, até lá no $1^{\circ}$ ano, eu encontrei o ambiente mais propício [...] Eu acredito muito nessa questão da aprendizagem pela interação, pelas brincadeiras. (Entrevista)

$O$ encantamento da professora com a infância e sua vivência em turmas de educação infantil constituíam sua prática pedagógica e pode ser percebido como um princípio que orienta a maneira como ela se relaciona com os alunos. Para a professora, o fato de os alunos não fazerem mais parte da Educação Infantil, que tem uma organização específica para o desenvolvimento das crianças, não significa que eles deixaram de ser crianças. Alguns trechos do complemento de frases aprofundam essa análise:

41- Meus alunos alunos não. Crianças!

44- As crianças me encantam.

29- Minha turma afetividade, amorosidade e encantamento

38- Os outros relação e interação

64- Eu não quero perder o encanto, a amorosidade e a afetividade

Nos diversos instrumentos, Alice por vezes reiterou seu envolvimento emocional com a turma, como pode ser observado no trecho seguinte:

Não, não vou desejar feliz dia do estudante! Prefiro pensar em vocês como crianças, sujeitos de possibilidades e que todos os nossos dias sejam felizes. \#amoinfinitamente (Facebook - publicação no dia do estudante)

Para a professora Alice os alunos eram, antes de qualquer coisa, crianças e, portanto, deveriam ter oportunidade de ser comportar e se desenvolver como tal, com todas as características e direitos respeitados. Esse entendimento, juntamente com o envolvimento emocional que se foi construindo, estava na base das relações entre elas e os alunos na sala de aula. 
Alunos como sujeitos protagonistas de seus processos de aprendizagem e desenvolvimento

A professora Alice buscava incentivar a autonomia dos alunos não dando respostas prontas, instigando a reflexão e orientando para que eles tomassem decisões. Quando algum aluno fazia uma pergunta, geralmente ela devolvia a questão de uma outra forma para possibilitar a organização do pensamento pela própria criança, como pode ser observado no episódio abaixo:

Depois de a professora ter explicado várias vezes a realização de uma atividade, Clarice pergunta: tia, o que é pra fazer?

A professora se aproxima de Clarice e diz: vamos relembrar aqui. O que você vai fazer com essas letras que o Bento entregou?

Clarice: cortar e colar.

Professora: e o que as letras vão formar?

Clarice: o nome.

Professora: isso, o nome do livro, "O vestido de Kaká". E como você vai montar o nome?

Clarice: tem que pensar.

Professora: é, tem que pensar. E se você precisar de ajuda, onde você pode olhar?

Clarice: No quadro.

A aluna estava com os papéis espalhados na mesa e ainda não havia começado a realização da atividade alegando não saber o que era para fazer. Entretanto, suas respostas demonstram que ela já possuía as informações que puderam ser organizadas a partir das perguntas da professora. Não dar respostas prontas e incentivar a reflexão também apontam para uma concepção de aprendizagem que vai além do treino e da reprodução, privilegiando operações mais complexas do pensamento. A aluna já compreendia que para formar um nome precisaria "pensar", provavelmente porque eram frequentes situações em que a professora propunha situações de reflexão sobre o sistema de escrita. Por outro lado, se ela tivesse dificuldades sabia que não haveria problemas em olhar no quadro, onde o nome do livro "O vestido de Kaká” já estava registrado, juntamente com outras palavras da história. Para a professora Alice os alunos deveriam refletir durante a realização da atividade, o que não os impedia de ter o apoio visual, tão importante nessa fase de aprendizagem da leitura e escrita.

O protagonismo dos alunos também se expressava a partir das escolhas pedagógicas da professora. Uma das atividades que direcionava o trabalho pedagógico com a turma era o projeto "Gente tem nome e sobrenome". O objetivo do projeto era trabalhar a identidade dos alunos a partir de seus nomes e suas histórias de vida. Além disso, a partir do nome de cada aluno eram trabalhados os conteúdos relativos à aprendizagem de leitura e escrita, como a compreensão do funcionamento do sistema de escrita alfabética. A cada semana o foco era um 
ou dois alunos e várias atividades eram desenvolvidas a partir de seus nomes, dentre elas uma entrevista.

A forma como a entrevista era organizada garantia que os alunos se tornassem os protagonistas daquela atividade, em que não apenas a criança entrevistada tinha voz, mas todos os outros alunos na medida em que podiam fazer qualquer pergunta ou comentário. O diálogo seguinte, parte de um episódio em que o aluno Tiago estava sendo entrevistado, sendo este um um indicador do protagonismo das crianças. Nesse momento, o aluno a ser entrevistado senta em uma cadeira baixa à frente da turma, enquanto os outros colegas se posicionam ao redor dele, sentados no chão em um semicírculo, o que eles chamam de "rodinha".

Lucas: Você já andou de skate?

Tiago: Já!

Lara: O que você mais gosta de fazer?

Tiago: Jogar futebol.

Adriano: e por que você nunca me convida e não convida todo mundo pra jogar futebol?

Professora sorri e diz: hum, adorei a pergunta. Pode falar Tiago..

Tiago (pensa um pouco): por que aí vai ficar muita gente.

Clarice: Mas futebol é muita gente mesmo!

Tiago desvia o olhar como se quisesse desconversar.

Marcelo: $O$ que você gosta de comer?

Tiago (pensa um pouco): granulado e brigadeiro.

Adriano: E por que você não convida eu e o Fernando e todo mundo quando traz sua bola?

Professora (dando risadas): pode falar o que você quiser Tiago, não precisa ter vergonha.

Tiago: É por que...as vezes...tem gente que entra no futebol e não sabe jogar futebol...e aí chuta a bola com o bico do tênis.

Professora: ahhh tá. Mas aí agora você pode explicar pra eles que não pode chutar a bola com o bico do tênis e pode convidar eles pra jogar, né?

Tiago balança a cabeça que sim.

Renato: Você já assistiu Guerra Civil?

Tiago: Não, mas eu já sei que o Capitão América ganha.

Renato: eu já assisti.

Clarice: Você já brincou de boneca?

Tiago: Não!

Professora: Você nunca brincou de boneca com a sua irmã?

Tiago: não, quando é assim eu pego o Ken.

Professora: entendi, você usa o boneco, né.

Marcelo: e por que os homens jogam bola e as mulheres são líderes de torcida?

Bate o sinal para o recreio.

Durante a entrevista, assim como em outros momentos de atividades coletivas, a professora ia organizando os turnos de fala para garantir a participação de todos os alunos e o respeito àquele que estava falando. Ainda assim, eram as perguntas das próprias crianças que direcionavam a atividade. Não existia pergunta certa ou errada, pergunta adequada ou inadequada, tudo que eles queriam saber sobre o colega podia ser perguntado. Nesta e em outras entrevistas já observadas, percebeu-se que surgiam assuntos diversos e distintas oportunidades de diálogos entre os alunos. Algumas vezes, a professora complementava a pergunta de uma criança ou acrescentava outras, como foi o caso de outro episódio em que ela indagou ao aluno 
entrevistado: "qual é o seu maior medo?" e "qual é o seu sonho?" Dessa forma, além de abrir espaço para os alunos perguntarem a partir de suas perspectivas, a professora também inseria o interesse dela em conhecer melhor aquela criança.

No episódio descrito foram feitas perguntas que remontavam às próprias experiências de quem estava perguntando, como no caso da pergunta sobre o filme; questões sobre as experiências do aluno que estava sendo entrevistado, seus gostos e interesses; e questões que envolviam o relacionamento interpessoal entre as crianças, como a insistência de Adriano em saber por que nunca é convidado para jogar bola.

Fica claro que, mesmo com a primeira resposta de Tiago, Adriano não se dá por satisfeito e continua insistindo na pergunta. Neste momento, a situação deixa de ser apenas uma entrevista direta, para tornar-se uma atividade dialógica que traz a possibilidade de pensar sobre esse problema entre os alunos. A professora percebe isso e incentiva que Tiago se posicione de maneira sincera, provavelmente por considerar que a pergunta de Adriano era interessante para provocar aquele aluno, no sentido de gerar reflexões. Tiago era uma criança participativa nas aulas e sempre levava brinquedo no dia da quadra, entretanto geralmente brincava com os mesmos colegas, outros três meninos que fazem parte de um grupo que se auto intitulavam "Os justiceiros". Por vezes, a professora relatou situações descontraídas desse grupo de alunos, valorizando a amizade entre eles, entretanto já havíamos observado situações em que ela incentivou que os alunos fizessem novas amizades e integrassem outros colegas em suas brincadeiras. Entendemos que, por conhecer essa especificidade do aluno e por acreditar que seria interessante ele interagir também com outros colegas, a professora incentivou o questionamento de Adriano. Dessa forma, esse momento de provocação e problematização se apresenta como potencialidade de desenvolvimento, visto que pode gerar posicionamentos reflexivos que encaminhem para a geração de novos processos de subjetivação em relação ao complexo conjunto de aspectos da experiência escolar.

Além disso, ao perguntar se o aluno já brincou de boneca e o motivo pelo qual os homens jogam bola e as mulheres são líderes de torcida, os alunos estavam problematizando questões de gênero, tema que já havia sido discutido no começo da aula a partir do comentário de um aluno sobre "rosa ser cor de menina". Entendemos que essas discussões realizadas na sala de aula vão gerando possibilidades de reflexão que se expressam em momentos que não necessariamente tem relação direta com a questão discutida, como foi o caso da entrevista.

Essa atividade de entrevista, pelo seu caráter aberto e dialógico, apresentava-se como um momento rico de aprendizagens e relações entre os alunos e entre alunos e professora. $\mathrm{O}$ curso dos diálogos estimulava a discussão entre os sujeitos, onde eles poderiam desenvolver 
emoções e reflexões no curso das informações. A partir das respostas às perguntas, não só a professora, mas toda a turma tinha a possibilidade de conhecer mais sobre aquele aluno que está sendo entrevistado. Como toda a turma ficava envolvida em atividades relacionadas àquele aluno específico, gerava-se oportunidade de todos os alunos terem um momento de maior visibilidade. Ademais, a maneira como a entrevista era organizada pode ser entendida como um indicador de que os alunos têm lugar central no desenvolvimento das atividades.

Ainda em relação a entrevista, a professora poderia, por exemplo, levar uma lista com perguntas já pré-elaboradas para fazer ou até mesmo conduzir as questões segundo aquilo que ela considera ser relevante, entretanto, em vez disso, deixa que as crianças perguntem livremente, segundo seus interesses e de acordo com a criança que está sendo entrevistada. Se já houvesse uma estrutura rígida de perguntas, provavelmente seria mais difícil surgir questões tão específicas, como foi a pergunta de Adriano e as questões sobre gênero. Neste sentido, a organização da atividade proposta permite que os alunos sejam considerados em suas singularidades.

A partir de um conjunto de indicadores, compreendemos que a professora incentivava a participação dos alunos por compreender que eles deveriam ser sujeitos do seu processo de aprendizagem e desenvolvimento. Considerando que a aprendizagem é um processo da subjetividade, em que o sujeito não aprende apenas como intelecto, mas como sistema complexo, em que se articulam dimensões das configurações subjetivas de sua história de vida articuladas com a produção de sentidos subjetivos das experiências atuais nos diversos contextos que o sujeito faz parte, González Rey (2006) salienta que a aprendizagem deve supor uma prática dialógica e singular.

O caráter singular da aprendizagem vai nos obrigar a pensar em nossas práticas pedagógicas sobre os aspectos que propiciam o posicionamento do aluno como sujeito da aprendizagem, o que necessariamente vai implicar o aluno com suas experiências e ideias no espaço do aprender. Isso é conseguido não apenas com os aspectos técnicos envolvidos na exposição de um conteúdo, mas com o desenvolvimento de relações que facilitam o posicionamento ativo e reflexivo dos alunos [...] (GONZÁLEZ REY, 2006, p. 38)

Ao destacar o posicionamento reflexivo dos alunos o autor não está se referindo a um pensamento lógico-cognitivo, pois o pensamento se define como um processo psicológico também por seu caráter subjetivo. O pensamento não se "pensa por si só", a partir de conteúdos operacionais, mas se constitui pelos processos simbólicos e emocionais que configuram processualmente a subjetividade individual do aluno. Sendo assim, o envolvimento do aluno vai depender das emoções que mobilizam a produção de sentidos subjetivos sobre o que se aprende e sobre o contexto social em que a aprendizagem ocorre. 
Em nossa construção interpretativa, entendemos que a professora incentivava a participação dos alunos por compreender que eles deveriam ser sujeitos do seu processo de aprendizagem e desenvolvimento. Alice demonstrava satisfação quando percebia atitudes das crianças que revelavam posicionamentos ativos e críticos. O diálogo a seguir, ilustra essa afirmação:

Tiago: Tia, não é justo. As meninas podem vir pra escola com um monte de enfeite no cabelo e os meninos não podem vir de boné.

Alice: Ué, mas eu nunca proibi vocês de usar boné na sala.

Tiago: Mas na escola é proibido. Eu não concordo.

Alice: E o que eu já conversei com vocês que quando a gente não concorda com alguma coisa, o que tem que fazer?

Tiago: Manifestar. Eu vou juntar meu grupo e vou manifestar.

Pesquisadora: E como você vai manifestar?

Tiago: Lá na Tia Tânia (diretora.)

A professora Alice comentou sobre esse diálogo na sala dos professores e, ainda, o reproduziu em sua rede social. Na publicação em que divulgou o fato, ela ainda escreveu:

"Olha o nível do diálogo! \#meutiago \#impressionante \#vontadedemorder" $(\text { facebook })^{11}$

Através dessa rede social, a professora Alice expressava suas opiniões sobre educação e sobre assuntos da atualidade, tais como: política, situação social e econômica do país, mídia, relações sociais, dentre outros. Compartilhava artigos e reportagens sobre escola, formação de professores, práticas pedagógicas e publicava também fotografias e comentários sobre a rotina de sua sala de aula e das atividades desenvolvidas.

A professora demonstrava ter um posicionamento crítico dentro e fora da escola, discutindo questões relacionadas à política, relações sociais e embates da profissão. Participava das assembleias e movimentos reivindicatórios dos profissionais da educação, fazia críticas nos momentos de coordenação pedagógica a posturas que considerava inadequadas e em conversas informais analisava reflexivamente a situação sócio-política do país. Sendo assim, interpretamos que a criticidade e o engajamento ativo eram importantes aspectos envolvidos na constituição subjetiva da professora Alice que se expressava em sua prática pedagógica.

Por sua vez, Alice também demonstrava o entendimento de que seus alunos deveriam ter uma formação crítica e tornar-se cidadãos ativos. Tal postura era incentivada não só em seus alunos, mas também em seus filhos. Nos momentos de coordenação pedagógica, presenciamos

\footnotetext{
${ }^{11}$ Optamos por manter a estrutura do texto da mesma maneira que foi publicado na rede social, às vezes contendo palavras abreviadas e hashtags. Hashtags são compostas por palavras-chave de um determinado assunto antecedidas pelo símbolo cerquilha (\#), e estas são escritas juntas, sem espaçamento
} 
episódios em que ela relatou com satisfação questionamentos e problematizações dos seus filhos. Entendemos que estes episódios indicam que a professora Alice compreende que a criticidade é um aspecto fundamental para a formação das crianças, que deve ser considerado não apenas na sala de aula, mas no desenvolvimento humano de maneira mais ampla.

O protagonismo dos alunos e o acolhimento das suas sugestões pela professora iam abrindo alternativas para a criação de um contexto participativo de modo que as crianças iam se reconhecendo naquele espaço social. Um exemplo interessante deste aspecto foi quando a turma ia iniciar os ensaios para a apresentação na Festa Junina. Em vez de chegar com uma proposta de apresentação definida, a professora Alice perguntou aos alunos o que eles gostariam de dançar. As crianças levaram diversas sugestões de músicas de ritmos distintos (funk, sertanejo, pop, forró), geralmente músicas que estavam sendo bastante difundidas nas rádios. Para acolher a sugestão de todos os alunos a professora Alice montou, através de um programa de edição de áudio, uma única música que unia trechos das músicas indicadas (normalmente o refrão ou a parte mais animada) mesclando com uma música base tradicional de quadrilha. A dança, chamada de "quadrilha maluca", era composta por passos tradicionais da quadrilha alternados com passos coreografados dos trechos das músicas indicadas pelos alunos.

Os alunos demonstraram bastante animação com a composição, se empenharam muito nos ensaios. Até mesmo alguns alunos que não iam participar da festa junina, devido à opção religiosa da família, pediam para participar dos ensaios, porque consideravam a música interessante. Como os ensaios aconteciam na quadra, por vezes presenciamos alunos de outras turmas assistindo e comentando que estava "muito legal" e que eram as "melhores músicas". No dia seguinte ao primeiro ensaio, quando cheguei à escola, Adriano foi logo dizendo, antes mesmo de me cumprimentar: “Tia, nossa música é bem legal, é assim ó... ” e começou a cantar demonstrando animação. Outros alunos comentavam: "tem uma parte que fui eu que escolhi"; "e aquela outra fui eu que falei". No dia da Festa Junina, a apresentação fez sucesso entre o público, que aplaudia e cantava junto com as crianças.

A possibilidade de os alunos opinarem e terem suas escolhas respeitadas, juntamente ao fato de a "quadrilha maluca" integrar diversos ritmos e músicas que estavam fazendo sucesso naquele momento possibilitou que as crianças e a comunidade se sentissem representadas naquela apresentação. Por outro lado, a mistura de ritmos não desvirtuava o caráter tradicional da festa junina, já que a base musical e os passos típicos da quadrilha foram mantidos. Este episódio demonstra uma preocupação da professora em acolher as sugestões dos alunos e torná-los partícipes de todo o processo. Aponta ainda, para uma valorização das 
experiências, hábitos e costumes dos alunos, bem como da comunidade no qual a escola estava inserida.

Nas atividades cotidianas, os alunos também tinham a oportunidade de fazer escolhas e dar sugestões. Atividades artísticas poderiam ser realizadas com os materiais que eles escolhiam; nas aulas de culinária a professora procurava incluir receitas que os alunos haviam sugerido; a organização de um evento ou de atividades poderia mudar de acordo com envolvimento da turma. Estes e outros exemplos apontam para o respeito aos interesses e opiniões dos alunos, de modo que a turma ia construindo uma identidade própria e as crianças se viam respeitadas e consideradas nesse processo. Sobre este aspecto, a professora esclareceu:

\footnotetext{
Embora eu e a Daniele (outra professora do $1^{\circ}$ ano) a gente faça um planejamento juntas, eu não gosto que a minha turma é...perca a cara, a identidade dela. Então eu sempre to introduzindo ali coisas que eles pedem, porque eles têm muito disso: "tia, a gente podia fazer isso", "a gente podia fazer aquilo" e porquê não fazer? Se eles têm necessidade de fazer um bingo, se eles têm necessidade... Vamos pra aula de receita que eles gostam muito, aula de comidinha, então porquê não trazer isso? Por que não eles me dizerem o que eles querem aprender? Porque eu acho que é bem por aí mesmo, eu que tenho que escutar as necessidades deles, eu que tenho que responder a esses anseios e não o contrário. Porque eles me dizendo isso eu também posso trilhar no meu planejamento um caminho que contemple aqueles conteúdos que estão no currículo. Acho que é por aí. (Entrevista)
}

As informações apresentadas evidenciam uma forte constituição da coletividade da turma a partir da emergência de sentidos subjetivos que implicavam o envolvimento ativo e emocional dos alunos com as atividades cotidianas. A mobilização dos alunos para participação estava articulada à qualidade das emoções envolvidas nas atividades e nas relações estabelecidas (GONZÁLEZ REY, 2005). O sentimento de pertencimento era um elemento que constituía a subjetividade social daquela sala de aula.

É certo que seria necessário um estudo individualizado para se analisar como esses aspectos se organizavam na constituição subjetiva dos alunos e na subjetividade social da sala de aula, pois as configurações subjetivas integram tanto as configurações da personalidade como as configurações subjetivas que se organizam no curso da ação. Dessa forma, o impacto das condições sociais não se dá por condições a priori ou pela relação direta com o conteúdo objetivo das atividades, mas sim através de uma rede complexa de sentidos subjetivos que se expressa na atividade atual do aluno (GONZÁLEZ REY, 2012). Na escola, por exemplo, as configurações subjetivas podem estar na base de problemas vivenciados pelos alunos na sala de aula, entretanto estas poderiam ainda ser modificadas a partir de novas configurações subjetivas envolvidas com as atividades realizadas e as relações estabelecidas. 
Sendo assim, apesar das situações elencadas não serem suficientes para uma análise da constituição subjetiva de alunos específicos, por exemplo, elas indicam uma configuração singular da produção subjetiva atual do espaço social da sala de aula que tem como elementos o sentimento de pertencimento dos alunos e a criação de oportunidades para o posicionamento ativo dos sujeitos.

\section{Individualização da relação/ olhar para o sujeito}

A busca por se aproximar dos alunos era uma estratégia da professora Alice também utilizada para investigar o processo de aprendizagem dos mesmos. Para isso, ela procurava, sempre que possível fazer um acompanhamento individualizado dos alunos. Essa era uma prática cotidiana da professora que sempre aproveitava os momentos em que as crianças estavam desenhando ou fazendo uma atividade que não exigia tanta intervenção para chamar um aluno em sua mesa para um acompanhamento mais individualizado, na tentativa de entender como estava sendo seu processo de aprendizagem de leitura e escrita.

Em uma situação de observação pudemos acompanhar mais de perto este momento. Neste dia a professora tinha trabalhado a história "Branca de Neve" e enquanto os alunos estavam desenhando a parte da história que mais gostaram, ela chamou Marcelo em sua mesa e pediu que ele escrevesse algumas palavras que faziam parte da história. A professora falou pausadamente a palavra e depois que ele escreveu pediu que ele fizesse a leitura apontando com o dedo. A cada vez que Marcelo fazia a leitura apontando o dedo ele ficava um tempo em silêncio, pensando, pegava a borracha, apagava e acrescentava ou trocava alguma letra. A professora aguardava pacientemente esse processo. Por exemplo, para escrever a palavra 'zangado' ele registrou inicialmente 'ZCD'. Quando a professora pediu para ele ler, ele mudou para 'ZCAD'. Ao ler novamente, corrigiu mais algumas vezes até chegar à escrita 'ZACADO'. Esse processo demorou um certo tempo, pois a cada vez que ele lia ficava pensativo até fazer a correção. Após a escrita de três palavras a professora percebeu que ele estava cansado e falou que ele podia sentar. No caderno de planejamento ela registrou a data, o nome do aluno e a seguinte informação: “Escrita alfabética. Realiza correção através de leitura. Apresenta insegurança."

Entendemos que essa atitude de chamar os alunos à sua mesa revela uma preocupação da professora em acompanhar de perto o desenvolvimento do processo de aprendizagem de leitura e escrita dos alunos, visto que nas atividades rotineiras nem sempre é possível fazer esse acompanhamento de maneira mais individualizada. Ao estar com mais atenção voltada a apenas 
um aluno a professora consegue ter acesso não apenas ao produto da atividade, que no caso é a escrita do aluno, mas ao percurso que ele faz até chegar a essa escrita. Neste momento ela pode perceber se o aluno repete oralmente as palavras, se se apoia no alfabeto que está colado na sala, se faz relação entre os aspectos da oralidade e do registro, dentre outros elementos, ou seja, se reflete sobre o processo de leitura e escrita, além de observar ainda de que maneira o aluno se coloca frente a esse desafio. Ao pedir que o aluno faça a leitura, a professora incentiva que ele reflita sobre sua própria escrita. Se a professora tivesse considerado apenas a primeira escrita (ZCD), sem conversar com o aluno ou permitir que ele revisse tal registro, provavelmente teria perdido a oportunidade de saber que o aluno já apresentava avanços e apenas o classificaria. Não foi apenas o fato de chamar o aluno para perto e pedir que ele relesse a escrita que contribuiu para esse processo, mas a relação estabelecida que favoreceu que o aluno, mesmo apresentando certa insegurança, se arriscasse a fazer novas tentativas de escrita. Ou seja, provavelmente não havia medo de errar, e se havia, ele não foi um impedimento para Marcelo se arriscar a novas formas de escrever. Compreendemos que essa situação indica que a professora valoriza a aprendizagem significativa que organiza o processo de desenvolvimento que está em construção, entendendo que deve considerar não apenas a aprendizagem que está produzida e consolidada, mas aquela que está em processo e que pode gerar possibilidades de desenvolvimento.

Depois de ter realizado o acompanhamento com o Marcelo, a professora chamou o aluno Mateus, que escreveu as palavras SENECA (soneca), ZACADO (zangado), FELISI (feliz). A professora repetiu o mesmo procedimento de pedir que o aluno fizesse a leitura ao final da escrita de cada palavra, de modo que o aluno lia rápido e não realizava correção. Sendo assim, ela registrou em seu caderno de planejamento: "Escrita alfabética, ainda não realiza correção através da leitura”.

Apesar dos dois alunos apresentarem uma escrita alfabética, fazendo o registro a partir do padrão consoante mais vogal, a professora percebeu diferenças entre eles. Essa diferença, apontada no registro da professora em seu caderno de planejamento, não foi destacada com o objetivo de comparar os dois alunos, mas como forma de ressaltar as especificidades deles neste momento em relação ao processo de aprendizagem da leitura e escrita. Além disso, o registro da professora em seu caderno permite que ela acompanhe os avanços dos alunos de maneira mais sistemática.

Entendemos que este tipo de acompanhamento individual, que se apresenta como uma prática cotidiana nesta turma, é uma maneira da professora conhecer os alunos, suas formas de pensar em relação ao processo de aprendizagem da leitura e escrita, suas dificuldades 
e avanços e seus modos de lidar com o desafio de pensar sobre a escrita. Percebemos que os alunos não se sentem incomodados por serem chamados à mesa da professora, talvez por essa ser uma prática corriqueira que não se restringe apenas a um grupo de crianças, ou seja, a professora não chama apenas os alunos que tem dificuldade ou aqueles que estão mais avançados, chama todos os alunos de acordo com as possibilidades do dia e das atividades que estão sendo realizadas pelo restante da turma. Além disso, há o respeito ao envolvimento do aluno. Observamos esse aspecto em um dia anterior quando a professora chamou Fernando em sua mesa e notou que ele ficou muito tempo pensando e não escrevia nada, então perguntou: “você quer voltar pra sua mesa?” O aluno respondeu que sim e ela permitiu que ele fosse sentar, explicando que poderia chamá-lo num outro dia.

A prática de analisar a escrita dos alunos de acordo com o nível da psicogênese é comum nas turmas de alfabetização da SEEDF, entretanto percebemos que muitas vezes essa análise se restringe a um momento específico, o chamado teste da psicogênese, que comumente tem sido usado mais para classificar os alunos do que para efetivamente orientar novas intervenções pedagógicas. A professora também realiza o teste da psicogênese, entretanto não limita sua análise a ele, visto que realiza o acompanhamento individualizado na sua prática cotidiana. Além disso, ela faz uma crítica à maneira como muitos professores realizam o teste e fazem utilização do mesmo. Num momento da coordenação pedagógica, em dinâmica conversacional, a professora relatou que o problema é que muitas pessoas usam o teste para classificar os alunos e não acompanham o desenvolvimento. Segundo ela, o teste deve servir para ajudar a orientar o trabalho, pensar em novas intervenções, mas para isso é preciso acompanhar o aluno de perto. "Tem gente que nem pede a criança pra ler, nem fica perto. Aí vira ditado", critica.

O acompanhamento individualizado permitia que a professora Alice tivesse acesso a algumas especificidades dos alunos no processo de aprendizagem e o registro desses momentos no caderno de planejamento apoiava a construção dos relatórios bimestrais a partir de uma avaliação contínua e processual. A avaliação que a professora fazia dos alunos não se restringia aos momentos específicos e formais. $\mathrm{Na}$ análise dos relatórios bimestrais percebemos que a professora destacava elementos singulares dos alunos, como pode ser observado nos trechos abaixo:

\footnotetext{
"Os seus desenhos são bem estruturados e apresentam uma riqueza de detalhes. Percebi um interesse especial pelas atividades que envolvem a dança e a música." (Relatório Bimestral - Clarice)
} 


\begin{abstract}
"Preocupa-se em ajudar os colegas que encontram dificuldades na realização das atividades propostas, constantemente busca alternativas para solucionar os conflitos existentes entre ela e os colegas." (Relatório Bimestral - Carine)

"Inicialmente apresentava uma insegurança muito grande para realizar as atividades propostas argumentando que não sabia como fazê-lo, após algumas conversas percebi que o Adriano tinha muito medo de errar, as intervenções foram feitas e atualmente a criança realiza as atividades com autonomia." (Relatório Bimestral - Adriano)
\end{abstract}

Além dos aspectos relacionados à aprendizagem e escrita dos conteúdos formais, a professora Alice registrava no relatório aspectos referentes ao relacionamento dos alunos com os colegas e com a escola, seus gostos e interesses, suas principais dificuldades e avanços. $\mathrm{O}$ destaque a elementos singulares dos alunos era possível pela proximidade que ela tinha com as crianças a partir da observação e conversas constantes. Essa aproximação muitas vezes ocorria a partir de uma intencionalidade da professora em ir ao encontro dos alunos que estavam apresentando algum tipo de dificuldade para, assim, buscar compreender melhor esse processo. Sobre isso, a professora Alice explica:

Você acaba ficando muitas vezes com o olhar mais voltado pra essas crianças que tem mais dificuldade, pra tentar trazê-los pra que eles avancem nessa questão da aprendizagem e...eu...e a busca também, porque muitas vezes eles não falam, eles ficam ali mais quietinhos, tem medo de errar, então tem sempre essa busca pela fala deles, que vai me orientar. (Entrevista)

Esse "olhar voltado" para as crianças não se restringia apenas às suas dificuldades, como ficou claro nos trechos dos relatórios bimestrais destacados, e indica uma atenção constante aos alunos no sentido de buscar conhecê-los melhor para propor as intervenções necessárias.

Eu acho que é mais essa questão do olhar, do escutar a criança, porque eu tô ali eu tô olhando, eu tô acompanhando a atividade, eu chamo eles na minha mesa pra saber e...eu acho que é mais dessa forma assim, porque embora ali tenha uma turma eu tento ver cada sujeito também, cada um na sua individualidade. (Entrevista)

A professora Alice, portanto, não ficava apenas na coletividade da sala de aula e buscava conhecer as especificidades dos alunos para atendê-los em suas necessidades. A busca pelo atendimento das necessidades dos alunos a partir das estratégias de registro do professor foi um aspecto investigado por Nunes (2015) que destacou:

os vínculos afetivos presentes nas relações entre professor e alunos não só participam efetivamente do processo de aprendizagem e desenvolvimento deles, como também são geradores de sentidos subjetivos que apoiam a organização do trabalho pedagógico do professor mobilizando as escolhas das estratégias pedagógicas mais favorecedoras à aprendizagem. (NUNES, 2015, p. 129)

Concordamos com a autora ao perceber que a estratégia de acompanhamento individualizado da professora Alice se constituía como um momento favorecedor para o 
conhecimento das necessidades dos alunos não pelo seu caráter pontual e avaliativo, mas principalmente por que estava ancorada em relações dialógicas nos mais diversos momentos da sala de aula. Através dessas relações a professora tinha acesso não somente à maneira de o aluno lidar com determinada atividade estruturada, mas às suas opiniões, experiências de vida, formas de lidar com os colegas e as brincadeiras, dentre outros aspectos que permitiam um conhecimento mais sistêmico do aluno que, por sua vez, poderia orientar a professora em suas intervenções. Por outro lado, em relações dialógicas e num clima ambiental de liberdade e acolhimento os alunos poderiam ter mais facilidade de se posicionar verdadeiramente. Dessa forma, ressaltamos que os sentidos subjetivos produzidos no processo relacional estão na base da aproximação entre professor e alunos que possibilita a intervenção pedagógica personalizada.

Ao tentar ver cada criança, a professora Alice acompanhava o processo de desenvolvimento dos alunos, salientando os principais avanços apresentados. Percebemos nos momentos de coordenação pedagógica e dos Conselhos de Classe que, ao falar sobre seus alunos, Alice sempre destacava pontos positivos e de crescimento. Mesmo quando comentava sobre alguma dificuldade que determinada criança estava apresentando, seu foco não estava na dificuldade em si, mas no que aquela criança poderia avançar.

Professora Alice: A maioria das crianças... a maioria não, eu posso colocar que todas
as crianças avançaram na questão desses conhecimentos mais sistematizados que
fazem relação a português, matemática e outras também avançaram muito na questão
da socialização, na questão da autonomia, da independência, então assim...é...tem o
Adriano né, que é...ele tem o diagnóstico de dislalia e hiperatividade, não é isso? Mas
é uma criança também que avançou muito nessa questão, então assim, ás vezes eu até
esqueço que ele veio com esse diagnóstico né. Psicóloga: É, mas o caso do Adriano...tem um problema motor também, é bem mais complicado né...

Professora: É, mas eu não percebo isso assim também não. Ele tem um problema motor? Tem, mas isso não impede ele de participar das atividades não. Ele desenvolveu bastante essa questão da autoconfiança, porque antes ele queria sempre que eu estivesse do lado, que eu tivesse ajudando a fazer a tarefa, ele ficava esperando... Agora não, ele já consegue fazer, ele tem esse negócio de tentar, e é aquele negócio "eu fiz" e ele não tá querendo a opinião se tá certo, se tá errado não, ele se acha. (risos) $\boldsymbol{E}$ isso foi muito importante no crescimento dele, ele se achar capaz. E eu acho que esse é o avanço mais significativo em relação a todos os outros. (Conselho de Classe $1^{\circ}$ Bimestre)

O diagnóstico de Adriano não era um limitador para a professora que fazia questão de enfatizar o avanço apresentado pelo aluno. O conjunto de informações advindos dos mais diversos instrumentos de pesquisa demonstram que a professora Alice buscava se aproximar dos alunos e valorizava os avanços apresentados, enfatizando o crescimento integral das crianças. 
As informações apresentadas nos indicam que a professora tinha uma atitude investigativa frente aos impasses apresentados pelos alunos, o que pôde ser constatado em relação ao aluno citado. No início do ano Adriano sempre aguardava a presença da professora para realizar as atividades propostas. Enquanto os outros alunos estavam realizando a atividade, ele ficava conversando, andando pela sala e contando coisas aleatórias para a professora. Quando a professora o questionava ele dizia que preferia ela terminar de ajudar outros colegas para ajuda-lo também. No momento do atendimento individualizado muitas vezes ele respondia corretamente, mas confirmava a informação várias vezes com a professora antes de fazer o registro escrito. Conversando com o aluno e analisando todas as situações descritas a professora percebeu, como destaca no relatório bimestral, que o aluno "tinha muito medo de errar" e passou a intervir com o objetivo de desmistificar esse medo. Dessa forma, a professora foi além de identificar apenas que o aluno não conseguia realizar a atividade de maneira autônoma, mas buscou entender o porquê dessa situação, que no caso era uma produção subjetiva do aluno que envolvia o medo de errar.

Segundo Tacca (2009), essa atitude investigativa do professor é fundamental para que ele ofereça a ajuda necessária ao salto qualitativo na aprendizagem do aluno. Concordamos com a autora que:

\footnotetext{
O instrumento metodológico para fazer emergir ou conhecer essa produção de sentido subjetivo serão as relações dialógicas, pois somente nessas situações em que acontecem perguntas e respostas, que serão abertos os espaços para as expressões do sujeito. Tal procedimento fará emergir indicadores das formas de pensar da criança, para ser identificado o caminho que ela toma e quais as interposições que as afastam da possibilidade de avanços na aprendizagem. No entanto, esse diálogo precisa ser construído em uma relação de confiança entre o professor e o aluno. (TACCA, 2009, p. 69)
}

As relações dialógicas serão, portanto, a base desse processo investigativo que poderá orientar as próximas decisões do professor em relação à intervenção com aquele aluno específico. Articulada a essa atitude investigativa, compreendemos que a professora possui um olhar voltado para o sujeito, considerando seus alunos como sujeitos de possibilidades. $O$ sujeito vem antes da dificuldade ou do diagnóstico e estes não são limitadores para o seu desenvolvimento.

Destacamos que há momentos em que a professora busca apenas a expressão individual dos alunos. Já em outros momentos, ela avança para a compreensão da singularidade. No caso do aluno Adriano, por exemplo, há indícios de que o olhar diferenciado da professora, bem com o modo de funcionamento do espaço escolar podem ajudar o aluno em seu desenvolvimento subjetivo. 
O fato de acreditar nas possibilidades de seus alunos não significa que o professor está desprendido de preconceitos, expectativas e momentos de tensão. Sobre esse aspecto, a professora Alice nos relatou sua mudança de percepção em relação a um aluno. Ela contou que quando viu o nome do Evandro na lista da turma ficou apreensiva, pois já o conhecia e percebia muitas reclamações em relação à criança e problemas envolvendo seu comportamento e contexto familiar. Entretanto, ao refletir sobre essa situação e se mostrar aberta à aproximação para com ele, a professora Alice percebeu outras características do aluno que desmistificaram a imagem que havia sido criada à distância.

\begin{abstract}
Aí de certa forma você vem com aquela imagem da criança. Nossa, mas depois você pára e fica olhando, igual eu olho pra ele assim tão fofo, tão carinhoso... aí eu penso: como que você forma esse preconceito, né, sobre as crianças?! No dia da reunião eu conversei com a mãe dele, aí eu fui e elogiei, falei assim: "nossa, o Evandro ele é um príncipe", falei desse jeito, "é muito educado, muito carinhoso", aí ela ficou super emocionada "vc tá falando do meu Evandro?" Eu falei: "é, o seu Evandro", "mas eu só vivia aqui na escola recebendo reclamação". Mas eu acho que teve também essa questão de eu me permitir, porque assim quando eu peguei a lista e olhei "é o Evandro"... Por que a maioria das crianças eu já conhecia, falei: "gente, eu vou tentar não chegar lá já assim dura, olha você é isso e acabou". Não, eu tentei chegar mais mole, conversei com ele... (Entrevista)
\end{abstract}

Neste trecho, a professora Alice reconhece que a imagem prévia que é formada sobre os alunos é, por vezes, carregada de preconceitos, seja porque tal imagem está marcada pela avaliação negativa de outras pessoas, seja porque ela é superficial, composta apenas por elementos externos nem sempre agradáveis à expectativa do professor. No entanto, apesar de ter tido receio no início, Alice não permitiu que a imagem pré-concebida fosse cristalizada e se colocou aberta a ir ao encontro do aluno. A partir de então, ela percebeu que o aluno se apresentava de maneira diferente. Este tipo de episódio evidencia a importância de se considerar o desenvolvimento como processo, sem permitir que percepções negativas sobre as crianças fiquem cristalizadas de modo que se deixe de enxergar o sujeito para enxergar um problema.

Além disso, vale ressaltar que o conhecimento que a professora tinha do aluno em questão se referia a outro momento de sua história e outro contexto em que ele estava inserido. Os modos como os alunos se posicionam são distintos nos diversos espaços sociais em que eles participam e tem relação com a produção de sentidos subjetivos sobre aquele espaço específico e sobre outros contextos e momentos de vida que vão se configurando de maneira complexa no momento da ação. Dessa forma, a criança não pode ser reduzida a um tipo de comportamento apresentado em um período específico de sua vida, em um contexto específico, afinal o desenvolvimento é processual, contínuo e constituído por uma multiplicidade de fatores. 
Importância da imaginação e da emoção no desenvolvimento infantil

A contação de histórias tinha lugar privilegiado na organização do trabalho pedagógico da professora Alice. Toda semana era trabalhado um livro infantil, que era apresentado inicialmente no pátio e, em seguida, na sala de aula. As apresentações no pátio envolviam professores de outras turmas e, geralmente, eram feitas com dramatizações. Este momento era sempre animado e fazia parte da rotina da escola. Na sala de aula, por sua vez, a professora Alice retomava fazendo a leitura do livro, pedindo para os alunos recontarem a história e propondo discussões sobre ela. As atividades da semana eram organizadas a partir dos temas e possibilidades trazidas pela história, onde a professora inseria os conteúdos curriculares. Além disso, as vezes a professora acrescentava outras histórias na sequência didática para fazer um contraponto com a história já conhecida.

Geralmente, a professora pedia para os alunos se organizarem sentados no chão para ouvirem a história ou conversar sobre ela. Em um desses episódios, uma aluna manifesta animada: "desde que você chegou, eu já sabia que tinha história!" Para iniciar, a professora Alice relembra os combinados em relação à maneira que os alunos devem se comportar neste momento, dizendo bem baixinho: "lembrando que agora tem que ter olhos de coruja, orelhas de elefante e boca de formiga".

Em um episódio observado, a professora levou o livro "Mamãe nunca me contou", que tem como narrador uma criança que apresenta vários questionamentos sobre curiosidades e segredos da vida, que suscitam vários temas, como por exemplo: gravidez, parto, cordão umbilical, escola, fada do dente, diferenças entre meninos e meninas, diversidade, dentre outros.

Alice foi lendo a história e levantando o livro de modo que todas as crianças pudessem ver as ilustrações. Os alunos foram fazendo comentários nos momentos que a professora pausava para mostrar os desenhos. Alguns comentários a professora apenas escutava e continuava a sequência da história, outros ela comentava ou explicava. Para exemplificar seguem alguns diálogos que ocorreram durante a leitura da história.

\footnotetext{
* Imagem de um menino numa banheira cheia de água e um jato de xixi para cima.

Fernando: o pipiu dele tá pra cima!

Professora: é pipiu?

Ferando: é tênis!

Professora (sorrindo) é pênis.

* Imagem de um casal formado por duas mulheres e outro casal formado por dois homens.

Adriano: é pecado!

Clarice: é sapatão!
} 
Professora: A gente já não conversou que as pessoas são diferentes? Então, todo mundo tem o direito de gostar de quem quiser, a gente tem que respeitar. Não é sapatão, não é viado, o nome certo é homossexual.

Tiago: Eu tenho um primo que ele é....ele é...

Professora: homossexual?

Tiago: não, ele é gay.

Professora (sorrindo): então, mas como eu disse, o nome certo não é gay, é homossexual.

A discussão é interrompida pela cantineira que chega na porta da sala para servir o lanche. A professora finaliza a leitura da história para que eles possam lanchar. Após o lanche, a professora relembra a história, fazendo um breve resumo.

Tiago complementa: tem também os homofóbicos, que é quem não gosta né.

A professora aproveita esse comentário para retomar questões sobre respeito ao próximo.

Neste mesmo dia já havia ocorrido uma discussão sobre as diferenças entre meninos e meninas, a partir de um comentário de um aluno que disse que "rosa não é cor de menino". A professora, por sua vez, questionou: "por acaso se você usar roupa rosa você vai virar menina?" e continuou a discussão problematizando esta fala. Surgiu, então, uma discussão sobre as diferenças entre um e outro, com a apresentação dos nomes dos órgãos genitais.

Durante a história, os alunos retomaram a questão a partir da imagem e a professora interferiu fazendo a correção do nome. Neste e em outros momentos percebe-se que não havia delimitação sobre o tipo de assunto que podia ou não ser dito na sala de aula. Mesmo quando se tratava de assuntos considerados polêmicos ou constrangedores a professora tratava o tema com naturalidade e conduzia a conversa de modo a permitir sempre a expressão dos alunos. A maneira como ela acolhe as expressões dos alunos e problematiza através de questionamentos apontam para a possibilidade de reflexão por parte dos alunos e incentivo ao pensamento crítico.

Em um outro trecho da história surge o seguinte diálogo entre os alunos:

* Imagem da fada do dente.

Fernando: Eu já vi a fada do dente.

Clarice: Mentira, não existe!

Leandro: Existe sim!

Carine: Só nos contos de fadas.

Manuela: Nosso pai que é!

Clarice: é, ele vai lá, pega o dente e põe a moeda.

Professora: ah eu acho que existe sim.

Clarice: existe nada.

Guilherme: existe!

Bento (olha pela janela e observa a chuva): só não existe na chuva, por que aí ela ia ter que desviar dos pingos.

É interessante perceber que a dinâmica que se estabelece na sala de aula a partir das histórias abre espaço para o diálogo não apenas entre professora e alunos, mas também entre os alunos que apresentam seus pontos de vista e defendem suas opiniões frente às discordâncias com os colegas ou ainda, complementam quando há concordâncias. A sala de aula vai se tornando, dessa forma, um ambiente propício ao diálogo e à imaginação. 
As rodas de conversa após as histórias se apresentavam como possibilidade de discussão de diversos temas, indo além da narrativa e da estrutura formal do livro. A partir da história contada os alunos faziam comentários sobre suas experiências, davam opiniões e expunham suas maneiras de pensar. A professora, por sua vez, ia fazendo perguntas que instigassem a expressão dos alunos e ia organizando os turnos de fala para garantir que todos tivessem seu momento. Geralmente, era uma atividade que levava bastante tempo, pois a professora explorava todas as possibilidades a partir da história e primava pela participação de todos. A seguir, os trechos de outro episódio que ocorreu após a história da "Branca de Neve e os sete anões" ilustram essa afirmação:

Lia: ô tia, eu já assisti Branca de Neve e o caçador.

Professora: é? Eu também já assisti. O que você achou?

Lia: Legal!

Professora: e se vocês fossem o espelho, o que vocês fariam?

Tiago: eu ia matar a rainha.

Professora: e aí você ia ser mau?

Tiago: Sim!

Professora: Então você ia ser igual a ela?

Tiago: Não!

Professora: Então em algumas situações a gente pode ser mau?

Tiago (pensa um pouco): Acho que sim.

Lia: Claro que não! Nunca, né?!

Professora: que tipo de história é essa?

Carine: Conto de fadas.

Professora: e onde ela existe?

Adriano: lá longe.

Carine: no pensamento.

Manuela: na imaginação.

Professora: isso, normalmente essas histórias começam com...

Renato: era uma vez. Igual Shrek!

Professora: isso! Igual Shrek, porque Shrek também é um conto de fadas.

Professora: o que significa viver feliz para sempre?

Mateus: é ter uma vida muito boa e sossegada.

Fernando: é ficar junto.

Professora: E ficar junto para sempre é ficar feliz?

Fernando: sim.

Lia: Não! Eu prefiro ter a cama só pra mim. O meu padrasto é muito folgado, recebe comida na mão. Aiai, não gosto nem de pensar!

Professora: então quer dizer que você não vai querer casar quando crescer?

Lia: eu não!

Professora: a tia Luana (pesquisadora) tá noiva, vai casar, ela vai ficar desanimada desse jeito.

Lia: melhor não casar. Eca!

Leandro: melhor casar sim!

Renato: é, pra ela não morar sozinha.

Professora: mas ela já mora com a filha dela. A pessoa não pode morar só com os filhos?

Lia: não, também não! Aí tem que cortar a barriga, também é nojento.

Professora (sorrindo): eita, que hoje você não quer nada, né!

Marcelo: também não precisa do amor romântico pra ser feliz.

Professora: verdade Marcelo, tem outras formas de ser feliz, né?!

Após a conversa sobre a história, Adriano foi até a mesa da professora e disse: eu acho que a Lia não gosta de pessoas. 
Professora (sorrindo): uai, ela gosta. Ela só disse que não vai querer casar.

Adriano: eu acho que ela não gosta não.

Professora sorri.

Percebe-se que a professora Alice utiliza a estratégia de questionar as elaborações dos alunos e, assim, vão se estabelecendo diálogos que vão além da temática e da narrativa da história. No diálogo com Tiago, por exemplo, podemos inferir que a professora Alice questionou para provocar reflexões. Apesar de querer matar a rainha, o aluno não considerava que isso era um problema, já que ela era uma vilã, ou ainda, entendia que em algumas situações as pessoas podem ser "más". Esse tipo de diálogo incentivava a expressão dos alunos e as discussões sobre os sentimentos e ações humanas em suas tensões e contradições.

Em outros momentos, a professora questiona para entender o pensamento dos alunos, como na pergunta "o que significa viver feliz para sempre?” Por sua vez, Lia traz suas experiências pessoais para expressar a opinião a respeito do casamento. A partir de então, surgem mais possibilidades de reflexão, onde os alunos se posicionam e manifestam opiniões divergentes. A turma, dessa forma, ia se tornando um espaço social de discussão de temas complexos e atuais, tais como diversidade, questões de gênero, casamento, felicidade, etc, em uma articulação com a vida para além dos muros da escola, compondo a subjetividade social da sala de aula. Interessante notar que mesmo com pouca idade as crianças apresentavam seus posicionamentos e questionamentos, demonstrando que é possível debater temáticas polêmicas em sala de aula sem a necessidade de impor limitações de temas e de momento certo para a discussão.

A professora utilizava os temas e personagens dos livros para preparar atividades de leitura e escrita, entretanto a exploração das histórias não se dava apenas para fins de letramento e alfabetização. As rodas de conversa após as histórias não se organizavam como uma preparação para a atividade de leitura e escrita, mas eram uma atividade em si mesma, que ganhava força no curso da ação pelas possibilidades de fantasia, imaginação e problematização gerada pela participação dos alunos. Para a professora Alice, as atividades com literatura eram relevantes também pela possibilidade de trabalhar as emoções. Sobre a escolha por direcionar o trabalho pedagógico a partir de histórias ela justifica:

Primeiro porque eu sou apaixonada por literatura. E aí também tem essa questão de que a leitura das narrativas ela se faz tão importante na vida das crianças quanto a brincadeira. Então assim é um educador estético natural também...e aí casa exatamente com o meu interesse. Então é uma resposta minha também, porque vai de encontro a uma coisa que eu acredito. É uma concepção de que é...através também dessas histórias que eu levo pra eles, eles conseguem ter respostas de formas simbólicas pros sentimentos que eles têm, pros anseios, pras angústias... eles conseguem se identificar com os personagens, eles trazem a própria história deles e contrapõe com a história ali...Então assim, é um trabalho que eu venho tentando...eu 
venho fazendo uso dele já tem um bom tempo, acho que uns cinco, seis anos e eu percebo que tem dado resultado. (Entrevista)

Um primeiro aspecto que podemos destacar a partir desse relato é a consciência da professora sobre suas escolhas pedagógicas. O fato de trabalhar com histórias se justifica por dois motivos: o interesse pessoal da professora e a potencialidade das narrativas para o desenvolvimento dos alunos. A professora Alice demonstrava ser realmente "apaixonada" por literatura nos constantes relatos sobre livros infantis, sobre novas histórias que ela tinha conhecido e sobre a produção cinematográfica a partir da literatura. Pelos comentários que eram feitos nos momentos de coordenação pedagógica e nos momentos informais, ficava claro que atividades como ir a livrarias, visitar feiras literárias, ir ao cinema e a eventos culturais faziam parte da rotina de Alice.

Além desse vínculo pessoal com a literatura, Alice também se aproximava do tema como interesse acadêmico. No ano anterior ao da pesquisa, ela havia concluído um curso de especialização em Educação Infantil, onde investigou, em seu trabalho final, questões relativas à imaginação e emoção das crianças a partir do trabalho com contos de fadas. Essa produção acadêmica, juntamente com o reconhecimento do trabalho realizado em sala de aula, trouxe para a professora Alice uma visibilidade no contexto da Regional em que trabalhava, o que culminou num convite para ela dar uma palestra sobre o tema para professores de Educação Infantil.

Esta palestra também foi apresentada na escola em que Alice atuava, contexto em que outros professores demonstravam reconhecer o diferencial do trabalho pedagógico que ela realizava. Um episódio que ilustra esse reconhecimento foi uma publicação na rede social que outra professora da escola fez direcionada à professora Alice. Além de ser colega de trabalho, essa professora era também mãe de um aluno da turma de Alice.

\section{“Essa é pra vc que 'ensina' emoção." \#gratidão (publicação no facebook)}


Além do trabalho com as histórias a professora Alice buscava incentivar a imaginação dos alunos a partir dos momentos de brincadeiras, que aconteciam todos os dias. No momento do trabalho diversificado com brinquedos, em que os alunos se direcionavam para um 
determinado grupo (casinha, construção, massinha, miniaturas e jogos) diversos materiais ficavam à disposição das crianças, trazendo várias possibilidades de brincadeiras de faz de conta.

Entendemos que a professora Alice realiza um trabalho intencional com histórias, direcionado à imaginação e emoções dos alunos, por considerar que este é um aspecto essencial na prática pedagógica. E, ainda, sua relação pessoal com a literatura e artes de um modo geral indica que este tipo de escolha não se apresenta como algo aleatório ou definido por questões unicamente metodológicas, mas está marcada pela constituição subjetiva da docente. Os trechos a seguir corroboram com essa afirmação:

[...] eu sempre tive muito forte essa questão das artes né, da literatura, do teatro, da dança, sempre gostei muito e sempre tentei trazer pra sala de aula. (Entrevista)

33- Meu maior prazer as artes

40- Quando estou sozinha imagino ainda mais

Em nossa construção interpretativa compreendemos que o vínculo pessoal da professora com a literatura e as artes de maneira geral, articulado às suas vivências tanto no processo de formação continuada quanto nas suas experiências profissionais representam uma fonte de sentidos subjetivos marcantes na sua configuração subjetiva e na constituição da docência.

Por ter essa relação pessoal com as artes e reconhecer o seu valor no processo educativo ela buscava garantir o acesso dos alunos a diversos tipos de manifestações artísticas. No período da pesquisa a turma da professora Alice realizou duas visitas à exposições artísticas no Centro Cultural Banco do Brasil ${ }^{12}$. Alice nos relatou que a organização do passeio foi uma iniciativa pessoal dela que, ainda nas férias, entrou em contato com a instituição para agendar essas visitas. Mesmo sem saber ainda qual seria a turma com quem estaria trabalhando, Alice achava importante que seus futuros alunos tivessem garantido esse acesso à produção artística. Mais uma vez percebemos o protagonismo da professora Alice que, em vez de aguardar ações externas, seja da instituição educativa ou de instituições governamentais, assume para si a responsabilidade de buscar alternativas para ampliar o acesso dos alunos à produção cultural.

A gratuidade do passeio facilitou com que a maioria dos alunos participasse. No primeiro passeio, os alunos visitaram a exposição do artista Mondrian, pintor modernista, e foram acompanhados por uma mediadora do local que trazia informações sobre as obras e a

\footnotetext{
${ }^{12}$ O Centro Cultural Banco do Brasil, localizado na cidade de Brasília, é um espaço multidisciplinar que apresenta programação nas áreas de artes cênicas, música, cinema, exposições e programas educativos.
} 
biografia do artista. No início da visita, uma conversa inicial tinha o objetivo de problematizar o conceito de arte, como pode ser visto no episódio seguinte.

Mediadora: $O$ que vocês acham que é arte?

Fernando: A arte que eu mais gosto é a arte maciais.

A professora Alice dá risadas.

Após algumas crianças responderem, Ruan interfere, se direcionando para a professora.

Ruan: Ô tia, a gente vai fazer arte aqui?

Professora: Aqui a gente só vai ver, mas a gente já faz na escola.

Ruan: Ah, eu queria fazer aqui. Lá é arte também?

Professora: Claro! E vocês são os artistas.

O diálogo relatado, juntamente com as constantes expressões artísticas que eram trabalhadas em sala de aula, possibilitava uma ampliação do conceito de arte e um entendimento de que qualquer pessoa pode ser um artista, não sendo necessária uma legitimidade ou status para isso. Nos dias seguintes à exposição, os alunos produziram telas no estilo de Mondrian e a professora montou um mural que foi exposto na escola. Mais uma vez, a professora divulgou o trabalho dos alunos em sua rede social, destacando:

“Eles arrasam sempre! \#pqsomosartistas”

"Hoje foi dia de visitar o CCBB e ouvir as preciosidades dos meus pequenos sobre suas impressões a respeito da arte. \#emoçãoeimaginação." (publicações no facebook)

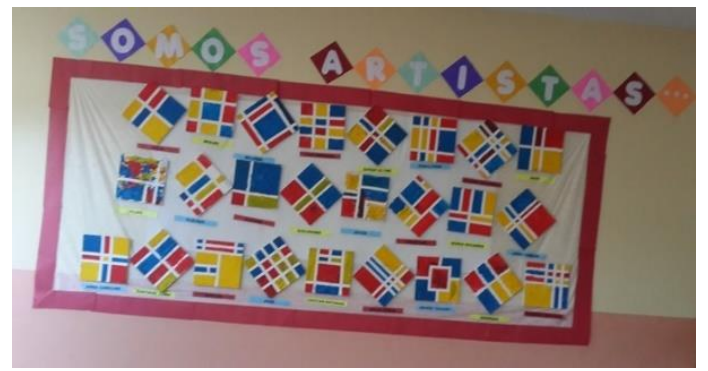

Fotografia do mural construído pelos alunos e professora.

Algumas semanas após esse passeio percebi que o aluno Eduardo estava concentrado em um desenho. Ele realizava a atividade que estava sobre a mesa, parava e voltava para o desenho, alternando entre as duas atividades. Quando me aproximei e questionei sobre o que ele estava fazendo, ele respondeu: "é arte."

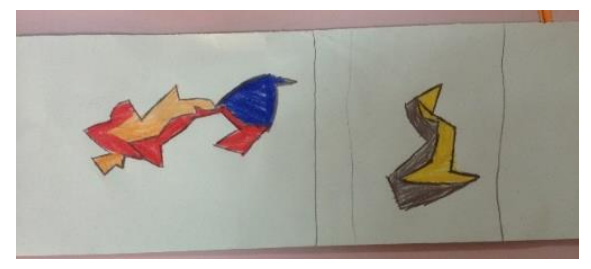

Fotografia do desenho do aluno Eduardo.

O destaque que a professora dava às produções das crianças e às suas considerações que, no trecho acima ela chama de preciosidades, indicava um sentimento de orgulho e satisfação 
em relação a seus alunos. O trecho a seguir em que a professora comenta sobre a finalização do primeiro bimestre, nos auxilia nessa interpretação:

Noossa! Eu estou assim...muito muito muito feliz, com a turma em geral, com o
avanço que eles tem tido... Porque muitas vezes você vai, quem olha de fora fala bem
assim "não, mas ele continua do mesmo jeito", mas é uma coisa que eu valorizo
muito, é uma criança que ele já não precisa de mim o tempo todo pra tá fazendo a
atividade, é uma criança que já tem autoconfiança, é uma criança que... que já ta
reconhecendo algumas letras, é uma criança que já brinca, uma criança que já vai
pro recreio. Então assim, não é só a valorização de leitura e escrita, é a valorização
do sujeito, do crescimento dele pessoal também. Então assim eu fico...Nossa! Eu fico
muito deslumbrada e eu sou muito boba em relação a isso, porque eu fico muito
emocionada com essa questão do crescimento deles, das posiçâes, das considerações
que eles fazem, tanto na fala quanto na escrita, então assim... Ah, eu sou
apaixonada por eles! (risos) (Entrevista)

A alegria que ela demonstrava ao relatar os comentários dos alunos e seus avanços nas mais diversas áreas nos sinaliza um envolvimento emocional com as crianças participava da produção de sentidos subjetivos relacionados à sua profissionalidade docente e à sua atuação com a turma. Por sua vez, essa produção subjetiva constituía o desenvolvimento do trabalho pedagógico da professora e a configuração subjetiva do espaço social da sala de aula.

O protagonismo e o posicionamento ativo da professora Alice no desenvolvimento do trabalho pedagógico nos indicam sua condição de sujeito, em que ela se mostrava capaz de abrir espaços próprios em relação ao contexto em que estava inserida. (GONZÁLEZ REY, 2005) A autoria na elaboração do planejamento e das atividades, seu comprometimento e responsabilidade e a busca constante por opções diversificadas para o trabalho com sua turma evidenciam um envolvimento ativo e intencional com a docência. De acordo com González Rey (2005) "o sujeito é constituído subjetivamente e suas ações são uma fonte constante de subjetivação que chega a ser constituinte dos próprios processos nos quais se constitui”. Dessa forma, a professora Alice representava, na sua turma e na escola, uma possibilidade de novas formas de subjetivação sobre o trabalho com crianças e, ao mesmo tempo, se constituía subjetivamente dentro desses espaços sociais. No curso da ação das atividades, a partir de um marcante envolvimento emocional, esse processo se desenvolvia e o momento atual tornava-se constituinte da configuração subjetiva da professora, retroalimentando sua prática pedagógica e os processos relacionais com os alunos. 
Envolvimento emocional como base das relações

Identificamos que a professora Alice tinha uma grande preocupação com o bem-estar das crianças, o que se apresentava como mais um elemento do seu envolvimento emocional com os alunos. Para além de considerar esse aspecto na organização do trabalho pedagógico, nos momentos informais e situações inesperadas percebemos intervenções da professora Alice que indicam uma preocupação com as questões afetivas dos alunos. Os episódios a seguir ilustram esse aspecto.

Leandro volta do recreio com rosto contrariado e visivelmente nervoso. A professora se aproxima e pergunta o que houve. Ele abaixa a cabeça na mesa. Renato responde por ele.

Renato: A gente reuniu o grupo e contou pra tia Tânia (diretora) que ele queria namorar com a Letícia.

Professora: Ah é?! E você queria, Leandro?

Leandro: Queria. E ela também!

Professora: E você ficou chateado porque seus amigos fizeram isso?

Leandro: Eu tô bravo! E confuso!

Professora: Você tá bravo e confuso?

Leandro balança a cabeça indicando que sim e abaixa a cabeça na mesa.

A professora se volta para o grupo e pergunta: E porque vocês fizeram isso?

Renato: Por que a gente não quer que ele namore.

Professora: Eu acho que vocês tão é com ciúmes dele? Ou será que é da Letícia?

Tiago: Não! Mas a gente não quer.

A professora pede para Leandro ir lavar o rosto e tomar uma água para se acalmar.

No episódio relatado nota-se uma preocupação da professora em saber como o aluno estava se sentindo em relação as experiências que tinha passado. Quando os alunos contavam algo ou quando a professora percebia alguma situação de tensão ou conflito ela questionava: “ $o$ que você achou disso?" ou "como você se sentiu a respeito?”. Nem todos os alunos davam explicações completas ou se abriam com facilidade, alguns apresentavam uma postura tímida e permaneciam calados ou davam uma resposta mais superficial. Entretanto, o que consideramos importante destacar é que a professora buscava ir ao encontro dos alunos para compreender as emocionalidades geradas nas experiências vividas por eles.

Compreendemos que a articulação dos aspectos analisados, como, por exemplo, o incentivo ao desenvolvimento dos processos imaginativos, o espaço dedicado às expressões artísticas e a atenção as emocionalidades geradas por seus alunos são indicadores de que a professora Alice considera o papel gerador das emoções no desenvolvimento dos alunos e que este aspecto constitui as relações que são construídas entre eles.

A professora Alice acreditava que a escola deveria ser um lugar prazeroso e que o processo de aprendizagem também deveria ser agradável. Este ponto emergiu durante a entrevista da seguinte forma: 
Eu tento tornar esse momento que eu tenho com eles mais leve, um momento mais alegre, que não seja penoso, que eles não sejam punidos. (Entrevista)

Este trecho apresenta-se como um indicador interessante por ter emergido de maneira indireta, já que era outro tema que estava em discussão. A pergunta que foi feita era referente à organização do trabalho pedagógico com a turma no início do ano e Alice trouxe a compreensão da sala de aula ser um ambiente prazeroso como aspecto fundamental. Complementando essa interpretação, percebemos que as publicações da professora Alice em sua rede social sobre as atividades desenvolvidas na escola sempre se referiam a momentos de alegria e diversão, como pode ser visto no trecho a seguir:

Hoje nosso dia foi uma gostosura. \#pqaprenderéumadelícia (publicação no facebook)

As aulas de culinária e de confecção de materiais artísticos eram dois momentos bastante apreciados pelos alunos. Nessas ocasiões, emergiam situações que sinalizavam um envolvimento dos alunos com a dinâmica das aulas.

No dia em que a professora levou a proposta de receita de "espetinho de salada de frutas", por exemplo, a animação dos alunos era explícita. Eles ajudaram a lavar e descascar as frutas e, ao final, cada um recebeu um espeto para introduzir os pedaços das frutas que queria, montando assim o seu espetinho. As crianças se divertiam com o trabalho de encaixar as frutas no espeto e tentavam montá-lo de forma bem colorida. Enquanto eles montavam seus espetinhos, a professora tirava fotos. Alguns alunos perguntavam: "ficou bonito?", "você vai mandar pra minha mãe?”. O diálogo a seguir explicita o envolvimento dos alunos.

Lia: Tia, a gente pode levar a touca pra casa?

Professora: Pode! Ela é descartável, da próxima vez usaremos outra mesmo.

Alunos: Obaaa!

Lia: Eu nunca mais quero sair dessa sala!

Ao final da aula Joyce se dirigiu até mim e disse:

Tia Luana, pra mim hoje foi o melhor dia!

Neste trecho de informação fica clara a alegria da aluna com a atividade realizada. Joyce demonstrava satisfação nas "aulas de comidinha" e por vezes comentava que "poderia ter todo dia”. Outros alunos também manifestavam um vínculo com esse tipo de atividade perguntando que dia fariam novamente e levando sugestões de receitas a serem realizadas.

Em dinâmica conversacional a professora Alice nos contou que Joyce era uma aluna que ficava um pouco distante e nem sempre aceitava aproximação, demonstrando muitas vezes um comportamento autossuficiente e independente. Após esse dia da aula de culinária ela foi se aproximando cada vez mais da professora, de modo a ter demonstrações mais explícitas de afeto e se abrir para o diálogo. 
Esse envolvimento também era perceptível nas aulas de artes. Às vésperas da Festa Junina, os alunos estavam montando um mural com caipiras, onde cada criança confeccionaria o seu usando como base uma colher de pau. Ao terminar a explicação sobre a proposta, Bento veio até mim e disse:

Bento: Legal essa parte, né tia?

Pesquisadora: Que parte?

Bento: Que a tia vai entregar uma colher de pau e um chapeuzinho pra gente montar o caipira! E ainda vai dar canetinha pra gente fazer o rosto!

Pesquisadora: Nossa, muito legal mesmo!

O aluno apresentou empolgação com a proposta de atividade e com os materiais que a professora colocou à disposição para a realização da mesma. Enquanto confeccionavam seus caipiras, as crianças se movimentavam pela sala de aula, escolhiam os materiais que queriam utilizar, trocavam ideias e sugestões com os colegas e, às vezes, solicitavam ajuda da professora e da pesquisadora.

Nessa proposta de atividade foi interessante perceber o envolvimento de um aluno específico. Como já foi dito, Daniel normalmente apresentava um comportamento mais retraído e distante e por vezes a professora manifestava preocupação por não conseguir se aproximar dele. Como já destacamos antes em outro episódio, nem sempre o aluno estava aberto a conversar, por vezes preferindo ficar em silêncio. Neste dia, entretanto, ele buscava constantemente a ajuda da professora para confeccionar a roupa do caipira. Daniel refez a gravata várias vezes e, ao pedir ajuda, explicava como queria que ela ficasse, demonstrando um zelo em deixar a produção artística "bem feita". Observamos que, às vezes, ele passava a semana toda brincando com o material que havia sido confeccionado na aula de artes, mesmo durante a realização de outras propostas de atividades. Percebemos que, nesses momentos, Daniel foi abrindo um espaço que permitia a maior aproximação da professora. Apesar de não apresentar demonstrações diretas de afeto, notamos que quando um grupo de alunos se aproximava da professora para abraçar e/ou conversar, Daniel também se aproximava, ficando um pouco apartado do grupo, mas com a atenção voltada para ele. Era como se ele também quisesse participar daqueles momentos, sem saber ao certo como tomar iniciativa. A professora Alice, por sua vez, notava essa situação e ia até o aluno iniciar alguma conversa. Esse olhar atento da professora era acompanhado de um processo de interpretação, pois ela não se limitava ao comportamento observável, mas ao que poderia estar por trás daquela postura que o aluno apresentava. No caso descrito, por exemplo, ela entendia que Daniel, apesar de não demonstrar explicitamente, estava querendo se aproximar e, aproveitava esses momentos para estabelecer uma relação mais próxima com ele. 
Em dinâmica conversacional com os alunos, questionamos quais eram os momentos que eles mais gostavam na sala de aula e a diversidade de atividades propostas apareceram nas mais diversas respostas:

Leandro: Eu gosto de tarefa de pintar, desenhar.

Renato: eu gosto de escrever.

Leandro: ah tia, também eu gosto de culinária também! Culinária é de bolo...

Evandro: E eu gosto de arte! E de brincar.

Mateus: também tem o parquinho

Carine: e a quadra!

Sônia: o mais legal foi ir pro passeio.

Pesquisadora: Quê mais?

Mateus: ficar brincando com seu melhor amigo.

Fernando: assistir filme.

Daniel: eu gosto quando a gente faz coisas.

Pesquisadora: Como assim? Que coisas?

Mateus: Tipo o quadrinho do Mondrian...

Carine: As flores

Daniel: Eu gostei mais da colher de pau.

Diogo: De brincar com o grupinho.

A multiplicidade de atividades que eram realizadas na sala de aula, incluindo uma variedade de propostas de brincadeiras e produções artísticas, facilitava o envolvimento dos alunos, no sentido de atender aos mais distintos interesses a partir de estratégias diversificadas. Dessa forma, os alunos iam se identificando com as aulas e a trama que se estabelecia naquele espaço social favorecia um envolvimento com a professora e o fortalecimento da relação entre eles, bem como sua implicação no processo de aprendizagem.

Pensar o tema das emoções na sala de aula torna-se fundamental pela natureza psicológica do aprender inseparável da subjetividade. A emoção se apresenta como condição do sujeito para atuar no espaço de suas relações sociais. De acordo com González Rey (2012, p. 35):

A configuração subjetiva é uma verdadeira "rede" de sentidos subjetivos que se expressam em emoções e processos simbólicos na atividade atual do aluno, processos esses essenciais para a motivação do aluno na aprendizagem.

O autor tem desenvolvido uma representação diferente da motivação humana que, em vez de ser vista como uma entidade cristalizada e a priori, é compreendida como configurações subjetivas que se organizam durante a ação e que envolvem configurações subjetivas da personalidade, mas em sua processualidade que integra novos sentidos subjetivos que vão se organizando na experiência vivida. (GONZÁLEZ REY, 2012)

Dessa forma, não podemos afirmar que o envolvimento dos alunos se dá pelas condições externas da atividade ou de maneira linear em relação a elas, entretanto no curso da ação dessas atividades a partir dos processos relacionais e dialógicos em que os alunos podem se 
posicionar ativamente de acordo com suas singularidades vão sendo geradas emocionalidades que podem facilitar a emergência de sentidos subjetivos que impliquem o envolvimento dos alunos na atividade em curso.

O envolvimento dos alunos com as atividades das aulas se articulava ao envolvimento emocional com a professora Alice. Em certa ocasião, Ruan ao passar muito tempo ao redor da mesa da professora, perguntou: “tia, eu posso te amar?” Alice relatou o episódio para vários colegas e se dizia emocionada sempre que falava a respeito. Ruan era um aluno que se apresentava participativo e sempre estava próximo à professora, conversando ou solicitando ajuda. Em dinâmica conversacional, Alice disse que muitas vezes ele solicitava ajuda mesmo sem precisar, só para ter a presença da professora ao seu lado e que, nesses momentos, ela o incentivava a continuar a atividade sozinho. Apesar de se sentir lisonjeada com o carinho do aluno, a professora destacava que ele não poderia ficar dependente dela ou restringir seu convívio social.

Percebemos que em algumas situações Ruan tentava usar essa proximidade que tinha com a professora a seu favor. Nas brincadeiras ou jogos ele tentava influenciar para que seu grupo fosse o vencedor, tentando obter alguma informação privilegiada a partir de palavras e atitudes carinhosas. A professora, por sua vez, percebia essa intencionalidade dele por trás das manifestações de afeto e, apesar de considerar interessante o fato de o aluno criar estratégias para alcançar seus objetivos, ela não permitia que isso interferisse no desenvolvimento dos jogos ou atividades que envolviam competição. Durante um jogo, quando Ruan tentava obter dicas da professora, Alice falou: "não adianta você ficar me adulando, eu não vou falar, isso é trapaça." O aluno sorria, mas continuava a tentativa.

Entendemos que esses episódios revelam mais uma vez que a professora estava atenta àquilo que está por trás do comportamento dos alunos, fazendo interpretações a partir do conhecimento que ela possuía dos mesmos, o que indica que seu olhar para o sujeito não se reduz ao viés cognitivo e/ou comportamentalista.

Apesar dos episódios relatados, presenciamos outras situações em que Ruan manifestava afeto pela professora, mesmo quando não havia possibilidade de barganha. $\mathrm{O}$ diálogo a seguir ilustra essa afirmação:

Ruan: ô tia, porque você não volta?

Professora: Voltar pra quem, José?

Ruan: Pro seu marido.

Professora: Por quê que eu devia voltar pra ele?

Ruan: Por que sim.

Professora: Uai, por que sim não é resposta. Por que você queria que eu voltasse pra ele?

Ruan: Por que sim.

Professora: Mas eu não gosto mais dele. 
Ruan: Por que não?

Professora: Ué, por que o amor acaba.

Ruan: $O$ que ele fez?

Professora: Uai, a gente tava brigando muito, não tava mais dando certo.

Ruan: Então acha outro!

Professora (sorrindo): Acha outro? É assim, é? Simples assim?

Ruan: É, por que se você se apaixonar aí vai se casar.

Professora: Sim, se eu me apaixonar eu posso me casar. Mas eu não quero mais me casar.

Ruan: Por que não? Vai ficar aí solteira?

Professora: Vou.

Ruan: Sem ninguém? Só com seus filhos?

Professora: Sim, e aí eu vou ser feliz, solteira, só com os meus filhos.

Ruan: Mas eu não gosto disso.

Professora: Mas não é você que tem que gostar, sou eu que tenho que gostar, não é não?

Ruan: Mas... (aponta para uma imagem de casal de passarinhos colado no mural da sala) oh lá aqueles passarinhos, viu? Você tem que fazer a mesma coisa!

Professora: Ah, que eles tão juntinhos com o coração no meio?

Ruan: Sim!

Professora: Aí eu tenho que ser daquele jeito também?

Ruan: Sim!

Professora: Mas eles encontraram uma pessoa certa e decidiram ficar assim.

Ruan: Então só você achar uma pessoa igualzinho você. Com os olhos assim, com a sobrancelha igual e com o cabelo preto e laranja. E um pouco gordinha.

Professora (sorrindo): Ah é? Aí eu vou achar uma pessoa igual a mim? E se essa pessoa for chata? Por que eu sou chata.

Ruan: Eu te acho chata?

Professora: Não sei, você acha?

Ruan: Você que sabe, você tem que adivinhar!

Professora. Acha! Você me acha chata!

Ruan balança a cabeça que não.

Professora: Você me acha o quê?

Ruan: Você que tem que adivinhar.

Professora: Eu não consigo. Algumas coisas você que tem que me dizer.

Ruan: Olha onde que tá apontando meu dedo.

Professora: Dois passarinhos...

Ruan: Se amam! A mesma coisa que eu te amo.

Professora: Ah é? (sorrisos)

Ruan: Agora você entendeu?

Professora: Agora eu entendi! Eu também te amo muito! Mas a tia vai continuar solteira, tá?

Ruan: Ãn, ãn, ãn. Vou achar alguém pra você!

Neste episódio Ruan deixa claro que "ama" a professora e que se preocupa com o fato dela estar solteira. Para o aluno, ela seria mais feliz se estivesse casada ou com alguém. Na sala de aula, era comum os alunos fazerem perguntas sobre a vida pessoal da professora e ela sempre que possível respondia. Quando eles falavam suas opiniões Alice questionava para possibilitar outros pensamentos, tal como pôde ser observado no diálogo acima, onde ela tenta explicar que não é necessário estar casado para ser feliz.

Assim como Ruan, vários outros alunos queriam estar sempre próximos da professora Alice. Muitos deixavam a atividade para ficar ao redor da mesa dela, onde geralmente ela estava atendendo algum aluno de maneira mais específica, ou a procuravam no horário do recreio para contar coisas diversas ou simplesmente para estar perto. Além disso, em vários momentos do 
dia as crianças dividiam suas experiências fora da escola com a professora que, assim, tinha a oportunidade de conhecer cada vez mais o contexto de vida de seus alunos.

Compreendemos que essa aproximação entre a professora e os alunos não era apenas a partir de uma intencionalidade direcionada ao apoio das crianças no processo de aprendizagem, mas acontecia de maneira espontânea devido ao envolvimento emocional que se foi construindo entre eles. Alice estava preocupada e engajada na aprendizagem de seus alunos, queria que eles aprendessem os códigos da leitura e escrita e demais conteúdos curriculares, mas mais do que isso, ela queria vê-los bem, felizes, brincando e se desenvolvendo como crianças, "sujeitos de possibilidades", como ela mesmo gostava de falar.

Apesar dessa perceptível aproximação entre a professora e os alunos, entendemos que esse envolvimento gerava emocionalidades diversas, que não necessariamente tinha relação linear com os aspectos observados. Ruan, por exemplo, aluno já citado por seu forte vínculo com a professora, às vezes demonstrava-se irritado pelo fato de ela não "ajudá-lo" na realização de alguma atividade ou quando ela precisava ser mais rígida com ele. Na maioria das vezes o aluno, de fato, conseguia concluir a atividade sozinho, entretanto, enquanto a professora buscava incentivar a sua autonomia, ele compreendia que ela o estava deixando "de lado". Em alguns desses episódios, ele fechava a cara, questionava a professora e demonstrava irritação com essa atitude. Em um dos momentos observados, Ruan respondeu com rispidez: "então tá, já que você não me ajuda eu vou fazer do jeito que eu quiser! E depois não vem dizer que tá errado não, viu!”. Alice, por sua vez, respondeu: “tudo bem!'. Nesses momentos, o aluno realizava a atividade com expressão facial contrariada, entretanto, pouco tempo depois já voltava às boas com a professora, inclusive mostrando o que havia realizado e conversando mil coisas, como gostava de fazer.

Em nossas observações, não presenciamos situações em que a professora constrangia os alunos por causa dos erros, pelo contrário, notamos que Alice focava no avanço que as crianças estavam apresentando. Entretanto, Ruan manifestou essa preocupação e se sentiu insatisfeito por não receber o auxílio que esperava da professora. Entendemos que tal manifestação não tem relação direta com a postura apresentada pela professora sobre erro ou sobre a atividade, mas por sentidos subjetivos gerados pelo aluno, que são provenientes de múltiplos fatores e contextos e que se articulam com o seu sentimento de aceitação pela professora. A reação da professora, por sua vez, ao responder "tudo bem” e demonstrar calma, juntamente com os apontamentos sobre o aluno nas dinâmicas conversacionais, indica que ela sabia que aquela era uma expressão momentânea, que fazia parte do seu processo de desenvolvimento e, por isso, não deveria causar maiores preocupações. 
Outra situação que demonstra as diversas emocionalidades que são geradas na sala de aula se refere às manifestações que indicavam ciúmes. Thalysson era um aluno muito carinhoso e comunicativo. Gostava de abraçar a professora e a pesquisadora e dizer palavras de afeto, estava sempre desenhando ou cantando na sala de aula. Muitas vezes ele pedia para ir à frente da turma cantar uma música e a professora geralmente autorizava e pedia que as outras crianças prestassem atenção. Nesses momentos, Alice elogiava sua disposição e coragem em ir à frente da turma se apresentar. Um dia, quando a professora comentou que estava com saudades de um aluno que estava faltando muito, Leandro respondeu: "tá com saudades só dele, é? E de mim?" Em outro momento, após a realização de um bingo, mesmo com a professora explicando que todos os alunos ganhariam um prêmio pela participação no jogo, Leandro chorou bastante por não ter ganhado e quando a professora foi conversar com ele, manifestou: "mas é que eu nunca ganhei nada!"

Essas e outras situações observadas em que o aluno demonstrava preocupação com o que os outros achavam dele indicam que na sala de aula emergiam em Leandro emocionalidades relacionadas a um sentimento de inferioridade e busca de aceitação. A professora relatou que ele era um menino sensível e emotivo e que, provavelmente, essas manifestações tinham relação com o contex to familiar, já que ele tinha dois irmãos mais novos que requeriam bastante atenção dos pais. Alice contou que conversava constantemente com a mãe dele, pois percebia que em alguns momentos ele se sentia "esquecido" no ambiente familiar. Durante a reunião de pais, a professora explicava aos pais de Leandro que, apesar de ser o mais velho, ele ainda era criança e, por isso, precisava de uma atenção maior. O sentimento de inferioridade em relação aos irmãos ou de esquecimento no contexto familiar pode se constituir como elemento essencial na configuração subjetiva da família que pode se impor sobre as experiências vividas no contexto escolar, entretanto tal configuração subjetiva pode se desenvolver e ser modificada por novas configurações subjetivas referentes às relações escolares (GONZÁLEZ REY, 2012). Faz-se necessário destacar que como não investigamos de maneira aprofundada a constituição subjetiva do aluno, por esse não fazer parte dos objetivos da pesquisa, não podemos fazer tal afirmação de maneira conclusiva. Entretanto, o exemplo apresentado torna-se relevante para se discutir a complexidade de elementos que constituem os processos relacionais entre professor e alunos na sala de aula.

Interpretamos que a aproximação que Alice tinha com os alunos, a partir dos constantes diálogos, pela preocupação em saber como eles estavam se sentindo e pelas atitudes investigativas, facilitava com que ela tivesse um conhecimento a respeito dos diversos contextos sociais que as crianças participavam. Dessa forma, ela tinha possibilidade de 
"enxergar" o aluno como um todo e perceber a multiplicidade de fatores que implicavam no seu desenvolvimento enquanto ser sistêmico e integral.

Os episódios relatados são apenas alguns exemplos das diversas emocionalidades geradas no espaço da sala de aula e que se configuram não apenas pelo comportamento manifesto e observado, mas pela produção de sentidos subjetivos que estão além dos comportamentos objetivos e que integram aspectos dos diversos contextos e momentos de vida das crianças. Essa complexidade de produção de sentidos subjetivos acontece o tempo todo nas salas de aulas de nossas escolas, entretanto vale ressaltar que nem sempre há uma preocupação por parte do professor em considerar essas questões. Nesta perspectiva, a turma da professora Alice apresentava um diferencial por ser um espaço aberto às mais diversas expressões dos alunos, e não apenas suas expressões cognitivas ou intelectuais, mas também seus sentimentos, receios e tensões. $\mathrm{O}$ fato de se preocupar com o que os alunos estavam sentindo e abrir espaço para discussão deste aspecto não significa que Alice teria controle ou direcionamento sobre os sentidos subjetivos gerados em seus alunos, pois estes são fluidos, dinâmicos e nem sempre conscientes. No entanto, o espaço dialógico criado na sala de aula, bem como o clima de acolhimento, abria possibilidade para que as diversas emocionalidades geradas pudessem ser manifestas e, assim, a criança poderia estar por inteira naquele espaço social.

Ao falar do envolvimento emocional entre professor e alunos é fundamental esclarecer algumas questões. Em primeiro lugar, vale ressaltar que estamos considerando o desenvolvimento humano de maneira sistêmica, em que múltiplos aspectos se integram de forma complexa na organização psicológica. Nesta perspectiva, supera-se a compreensão fragmentada de que cognição e afeto são elementos distintos. Na perspectiva teórica da subjetividade não cabe falar em afeto como um elemento externo que incentiva algo, mas sim em processos simbólicos e emocionais que são uma unidade e se organizam em configurações subjetivas na constituição psicológica e que acompanham todas as atividades humanas, dentre elas a aprendizagem.

Em segundo lugar, não se trata de abordar o envolvimento emocional como pieguice, mas de se compreender que, o professor queira ou não, tal aspecto constitui o funcionamento da sala de aula e as relações pedagógicas que se estabelecem naquele espaço. A forma como tal aspecto se manifestava no local da pesquisa se refere a um contexto singular, que não deve ser visto como modelo ou exemplo a ser seguido, mas sim analisado em relação às zonas de inteligibilidade geradas. 


\section{Comunicação com os pais}

A professora Alice também tinha a oportunidade de conhecer mais sobre os outros espaços sociais que os alunos participavam através da sua aproximação com os pais das crianças. Ela tinha um grupo no whatsapp composto pelos pais dos alunos, onde havia a troca de informações sobre as atividades realizadas, resolução de dúvidas sobre deveres de casa e relatos sobre experiências diversas das crianças. Alice enviava fotos tiradas dos alunos nas diversas atividades realizadas. Alguns pais, por sua vez, também enviavam fotos dos filhos em momentos de lazer fora da escola. Em uma ocasião, por exemplo, a mãe do Evandro enviou uma foto dele com um cachorro que ele tinha ganhado de presente. No dia seguinte, a professora comentou o fato com o aluno que, ao perceber a curiosidade dos colegas, pediu que a foto fosse mostrada para o restante da turma. Posteriormente, a mãe de Evandro relatou que ele chegou em casa "animado e feliz" porque seus colegas tinham visto a foto do seu cachorro. Entendemos que esse grupo virtual era uma possibilidade de criação de canais comunicativos com os pais e com os alunos, a partir da aproximação com os modos de vida das famílias e a troca de informações sobre as experiências dos alunos.

Quando necessário, a professora esclarecia para os pais os objetivos de determinada atividade ou as formas mais adequadas de auxiliar no dever de casa, sem dar a resposta pronta, por exemplo. Essa comunicação virtual era fortalecida pela comunicação presencial quando os pais iam na porta da sala buscar seus filhos e a professora Alice sempre buscava conversar ou contar algo interessante do dia. Essas estratégias facilitavam com que os pais também se tornassem parte daquele espaço social e do processo educativo que estava sendo desenvolvido.

Ainda no grupo virtual os pais incentivavam uns aos outros a se engajarem nos projetos que estavam sendo desenvolvidos. A título de exemplo, no segundo bimestre a escola realizou uma gincana para arrecadar alimentos para a festa junina, em que cada item correspondia a uma pontuação. A turma de cada etapa de ensino que obtivesse a maior pontuação seria a vencedora da gincana, com direito a um passeio em um clube no segundo semestre do ano letivo. A cada semana um determinado alimento tinha pontuação maior e a professora repassava essas informações para os pais através do grupo virtual, além do bilhete enviado pela escola. Muitos pais demonstraram-se participativos e, ainda, deixavam mensagens de incentivo aos outros pais no grupo, para que todos se engajassem. As crianças também demonstravam estar animadas, fazendo questionamentos sobre a pontuação e acompanhando todo o processo. A turma da professora Alice foi a vencedora do Bloco Inicial de Alfabetização. 
Além de se mostrarem participativos, os pais demonstravam satisfação com o trabalho pedagógico que estava sendo realizado e um reconhecimento das ações da professora Alice. Este aspecto era percebido em conversas informais e em constantes manifestações de agradecimentos através das redes sociais, como as que seguem abaixo:

Publicação de foto da festa à fantasia - mãe do Eduardo:

E hj na escola foi assim. Obg tia Alice. É professoras assim criativas e q ama aquilo $q$ faz q precisamos para nossas crianças. Muito feliz com ve sendo a professora do Davi. Obg mesmo. Bju. (publicação no facebook)

Publicação de fotos de uma atividade artística, que a professora enviou para os pais mãe do Bento:

Embora a maioria não possua infraestrutura e recursos materiais adequados, há educação de qualidade na escola pública. E isso se deve ao empenho de profissionais como a professora Alice. Reitero meus agradecimentos e admiração pelo seu trabalho. (publicação no facebook)

Comentário em uma foto da turma publicada pela professora - mãe do Tiago e professora na mesma escola:

Tendo vc como professora de escola pública é a comprovação de que posso acreditar mesmo numa educação pública de qualidade. Obrigada por me deixar aprender tanto com vc. E obrigada por fazer parte desse momento tão importante do meu João! Vc me faz querer ser uma pessoa cada dia melhor! (publicação no facebook)

A alegria e satisfação dos pais em relação ao avanço dos filhos e a diversidade de atividades que eles participavam integrava a produção de sentidos subjetivos de confiança e reconhecimento do trabalho pedagógico realizado pela professora. Este aspecto criava possibilidades para cada vez maior envolvimento dos pais gerando novos processos de subjetivação sobre a escola pública e a desenvolvimento das crianças. Por sua vez, tal envolvimento constituía a subjetividade social daquela sala de aula que se constituía como um espaço de coletividade.

\subsection{Aspectos da constituição subjetiva da professora Alice e sua articulação para a compreensão das relações estabelecidas com os alunos}

O período de convivência com a professora Alice articulado às informações procedentes dos diversos instrumentos de pesquisa nos possibilitou construções acerca de aspectos da sua constituição subjetiva que nos auxiliam na compreensão do seu fazer docente e, mais especificamente, dos modos como ela busca construir relações com os alunos. 
Inicialmente, construímos a hipótese de que a família se apresentava como um importante núcleo da configuração subjetiva de Alice, aspectos que foram expressos nos seguintes indutores do complemento de frases:

51- O passado um aprendizado.

59- Minha família minha base.

58- Em casa sou mulher, mãe, filha, sou eu.

4- Meu maior medo de não cuidar dos meus filhos.

Articulado ao valor simbólico-emocional de sua família, chamaram nossa atenção aspectos da história de vida de Alice, especificamente da infância, quando ela relatou sobre o processo de escolha profissional:

\begin{abstract}
Eu acho que desde a infância mesmo, que eu brincava muito de escolinha no fundo do quintal, a gente tinha umas bananeiras e eu sempre queria ser a professora, então eu sempre brincava. Aí também tem aquela história de que eu fui alfabetizada em casa, a gente morava em fazenda na época e quem me alfabetizou foi o meu irmão, só mais tarde que a gente foi morar na cidade, então acho que já tinha mais ou menos claro que...é...não precisaria ser necessariamente um professor pra tá fazendo isso. $\mathrm{E}$ aí depois veio a questão da igreja também, que aí eu comecei a ser professora da escola dominical na igreja e...ai quando eu terminei a oitava série na época eles tinham fechado o magistério. Aí eu fiz o $1^{\circ}$ ano e no final do $1^{\circ}$ ano reabriram o magistério, aí eu fiz a prova, aí comecei...quando eu fiz o vestibular também eu passei pra Pedagogia e passei pra Administração na UnB, aí eu optei por Pedagogia. Assim...é...eu costumo falar que eu nem sei. Eu nunca vi outra escolha, outros caminhos, não me imagino fazendo outra coisa não. (Entrevista inicial)
\end{abstract}

No relato apresentado identificamos que a infância foi um importante momento na sua constituição subjetiva. As brincadeiras e vivências na fazenda, local onde ela morava durante a infância, eram sempre relembradas como momentos de alegria:

55- Minha infância chão, terra, liberdade.

67- Quando eu era criança brinquei!

No processo de construção da informação começamos a levantar a hipótese de que a forma como a professora subjetivou sua infância era um dos elementos que constituía sua ação docente e se articulava ao encantamento que ela tinha com essa faixa etária, especialmente no que diz respeito às brincadeiras, descobertas e liberdade. Sendo assim, ao final da pesquisa retornamos ao campo com o objetivo de aprofundar este e outros aspectos que apareceram no complemento de frases e consolidar nossa construção interpretativa. Neste momento, a história de vida da professora Alice apareceu como importante marca da sua constituição subjetiva.

Apesar de ser jovem, a professora Alice veio de uma realidade familiar que nos remete às gerações passadas. Ela nasceu em uma fazenda, onde morou até os seis anos de idade. Era a sexta de sete filhos e nos contou que sua mãe trabalhava o dia todo para garantir as condições mínimas de criação dela e dos irmãos. Dessa forma, os irmãos mais velhos cuidavam dos irmãos 
mais novos. Sendo assim, Alice era cuidada pelos irmãos mais velhos e, posteriormente, também assumiu os cuidados da irmã mais nova.

Eu tava na $3^{a}$ série, eu chegava da escola e ia acender o fogão a lenha pra esquentar comida. Por que a gente foi criada naquele contexto bem machista de que as meninas é que tinham que cuidar das tarefas de casa. Aí eu esquentava a comida, dava pra minha irmã e ela ia pra escola. (Dinâmica conversacional)

A despeito de apresentar as dificuldades relativas ao contexto social em que vivia e as responsabilidades que tinha na infância, Alice se refere à sua infância com alegria e descontração. Os relatos a seguir, o primeiro de quando ainda morava na zona rural, e o segundo, de quando já morava na cidade, elucida esse aspecto.

\footnotetext{
Eu nasci na roça. Literalmente na roça, de parteira. A gente morava numa fazenda e a gente morou nessa fazenda até por volta de eu ter uns seis anos. Então assim, não tinha professor, mas eu tinha um irmão e aí foi ele que me alfabetizou. Alfabetizou a mim e o meu irmão. Então assim, a minha infância sempre foi bastante ligada à natureza. Cheia de responsabilidades também, mas bem ligada assim a essa questão da natureza, sendo muito livre, assim, criança sendo criança, brincando... sendo muito livre.
}

Eu sempre brincava das coisas “de menino”. Sempre na rua, carrinho de rolimã eu descia as ladeiras, brincava de corda, eu andava sem camisa... então era minha mãe chegar, ela me pegava na rua, eu apanhava. (sorri) (Dinâmica conversacional)

A análise das informações nos sinaliza que o que ficou marcado em sua constituição subjetiva não foram as condições objetivas de vida relativas as dificuldades socioeconômicas, mas sim as produções subjetivas relacionadas aos momentos de brincadeira e liberdade.

Mesmo afirmando que tinha mais contato com os irmãos, Alice se refere à mãe com afeto e demonstra reconhecimento pelo seu esforço e determinação na criação dos filhos. Ao falar do pai, que não morava com ela, mas com quem mantinha contato regular, ela se refere com carinho. Neste contexto, Alice apresenta uma forte referência no irmão que a alfabetizou. Tal referência se expressa ainda no fato de Alice ter dado ao seu filho o mesmo nome do irmão que, na ocasião do nascimento da criança já havia falecido.

A minha mãe, a responsabilidade que ela podia ter com a gente era trabalhar pra colocar as coisas dentro de casa. Ela não tinha outra maneira de cuidar, de olhar, por que ela não tinha outra opção. Se ela ficasse cuidando da gente a gente ia passar necessidade. Não tinha como, então ela tinha que trabalhar pra pelo menos garantir aquelas condições mínimas.

[...]

Eu sempre fui muito de observar e eu observava o contexto das minhas irmãs que tinham casado muito cedo, que tinham optado por aquilo. E tinha também meu irmão que sempre conversava isso. Ele sempre me chamava e chamava minha irmã pra olhar pra essas coisas e falava: "olha, observa a vida que as meninas estão levando, é isso que vocês querem? Veja como é a nossa mãe, então tentem fazer diferente". Então ele sempre mostrava a realidade pra gente pra falar assim: "vocês podem fazer diferente". Essa chamada dele sempre foi muito importante pra mim. (Entrevista) 
O mesmo irmão que a alfabetizou e que auxiliava na sua criação, a alertava sobre as possibilidades de ter uma vida diferente das irmãs mais velhas e da mãe. Compreendemos a relação com o irmão como um importante aspecto da configuração subjetiva de Alice envolvida no processo de formação pessoal que se articula à escolha profissional.

Naquela circunstância, para Alice a possibilidade de "fazer diferente" se dava através dos estudos.

Eu acho que era a única forma de fazer diferente, por que assim... a gente era muito pobre. Era a única forma que eu tinha de me destacar de alguma forma. E eu sempre gostei muito de estudar, sempre. Desde que eu me inseri nesse universo era pra mim uma forma de crescer... aí vieram as histórias. Eu nunca quis ganhar boneca, eu sempre queria ganhar livro ou ficar na rua brincando com os meninos. (Dinâmica conversacional)

Assim, a escolha da profissão foi também marcada pela possibilidade de ascensão social. Entretanto, não era apenas uma ascensão relacionada às condições socioeconômicas de vida, mas também uma oportunidade de crescimento pessoal e de ter uma vida diferente. Articulada à referência do irmão, Alice tinha uma produção subjetiva de não identificação com o modo de vida das mulheres da família, pois não gostava de tarefas domésticas e apresentava um posicionamento crítico frente à essa realidade

No contexto social que vivia ela vislumbrava apenas duas opções: seguir o modelo da mãe e das irmãs que se casaram cedo e se dedicar à vida doméstica ou ter uma vida diferente através dos estudos. Para além desse aspecto, havia ainda o gosto pelos estudos, que se articula ao fato dela ter sido alfabetizada pelo irmão antes de ingressar na escola e se expressava pelo interesse por livros e por crescimento pessoal.

Articulado a esses aspectos do contexto familiar, Alice teve experiências que também impactaram na escolha profissional. Em busca de independência começou a trabalhar muito cedo, com 13 anos de idade, como cuidadora de crianças em uma escola da cidade em que morava. Além disso, foi professora na escola dominical da igreja, onde pôde mais uma vez ter contato com crianças. Posteriormente, fez o magistério e, em seguida, passou no vestibular para dois cursos diferentes, optando pelo de Pedagogia.

Passei em dois vestibulares: Administração e Pedagogia. E optei por pedagogia, por que no magistério eu já vi que era aquilo que eu queria. Não faria outro curso superior, ainda não consigo me pensar em outro contexto, então assim tem alguns convites pra sair e tudo, mas ainda não. Eu ainda me realizo dentro de sala de aula. (Entrevista)

A articulação das informações apresentadas nos indica que o processo de escolha profissional da professora Alice foi configurado subjetivamente por múltiplos aspectos que se inter-relacionam, tais como: a relação com o irmão como importante configuração 
subjetiva envolvida na sua formação pessoal; a produção de sentidos subjetivos relativas à realidade feminina dentro do contexto social e familiar que vivia; as vivências com a infância nas experiências profisssionais e pessoais; e a subjetivação da sua infância como importante momento de liberdade e brincadeiras. Além disso, destacamos o aspecto de gênero que aparece na história de vida da professora Alice (cuidadora de crianças, as tarefas domésticas, a vontade de ter uma realidade diferente das irmãs mais velhas) e que participa também da constituição subjetiva da sua escolha profissional.

Outro ponto que merece destaque no trecho acima é a relação da professora com a docência, quando expressa "eu ainda me realizo na sala de aula”. Apesar de já ter atuado como Coordenadora Pedagógica e Supervisora Pedagógica em anos anteriores à pesquisa, e ainda receber muitos convites para esses cargos, Alice sempre destacou que sua preferência de atuação é na sala de aula, especialmente com turmas de Educação Infantil ou $1^{\circ}$ ano do Ensino Fundamental. Ao falar sobre essa escolha, ela destaca:

Eu me encontrei mesmo na educação infantil e $1^{o}$ ano. $2^{o}$ ano já não foi uma
experiência assim tão boba, eu já tive uma experiência, mas ainda prefiro educação
infantil e $1^{o}$ ano. O quê que me encanta? Essa questão da interação entre eles, da
espontaneidade, da escuta, do lúdico, das brincadeiras, porque querendo ou não,
embora eu acredite que isso tem que permear todo o processo educativo, é...eu acho
que na educação infantil, até lá no $1^{o}$ ano, eu encontrei o ambiente mais propício
e...você acaba não sofrendo tanto julgamentos quanto você sofreria nas outras, tantas
cobranças por parte da escola, por parte dos pais, porque eles querem aquelas
respostas imediatas, construções imediatas e eu não... a minha linha de pensamento,
a minha forma de trabalhar não é dessa forma, não se dá assim. Eu acredito muito
nessa questão da aprendizagem pela interação, pelas brincadeiras. (Entrevista)

O relato indica o encantamento da professora com a infância, aspecto já destacado anteriormente como princípio de sua ação pedagógica e da relação que estabelece com os alunos. A opção pela Educação Infantil e $1^{\circ}$ ano do Ensino Fundamental se justifica pelo fato de serem ambientes mais propícios ao desenvolvimento de um trabalho pedagógico que privilegie as brincadeiras e a ludicidade como processos de aprendizagem. A professora ainda nos apresenta um posicionamento crítico sobre a cobrança dos pais e da escola frente a respostas imediatas. Este aspecto indica um elemento da subjetividade social da instituição escolar relacionada ao processo educativo, ainda marcado por uma visão quantificável e acumulativa da aprendizagem, onde os conteúdos curriculares se sobrepõem às construções e produções dos sujeitos.

Alguns trechos do complemento de frases aprofundam essa análise sobre $o$ encantamento da professora com a infância:

41- Meus alunos alunos não. Crianças!

44- As crianças me encantam.

29- Minha turma afetividade, amorosidade e encantamento 
38- Os outros relação e interação

64- Eu não quero perder o encanto, a amorosidade e a afetividade

Em sua prática pedagógica, Alice demonstra alegria e emoção com as descobertas das crianças. Muitas vezes se diz encantada e surpresa com os posicionamentos dos alunos e faz questão de dividir com os colegas de trabalho esses posicionamentos que ela tanto considera importante. A análise dessas informações nos sinaliza que o encantamento com a infância e o envolvimento emocional com os alunos, em que os momentos de descobertas e espontaneidade das crianças se expressam, se apresentam como elementos marcantes da sua configuração subjetiva da docência no momento atual.

Alice tem um envolvimento emocional com seus alunos e sente prazer em estar com as crianças e contribuir para seu desenvolvimento, por isso percebe a sala de aula como "seu lugar", o lugar onde "se encontra". Sobre a significação da docência, ela salienta:

54 - Ser professora afetividade, emoção e vida 10-Ser professor é uma realização pessoal e profissional

O envolvimento emocional de Alice com as crianças não deve ser interpretado de maneira piegas, pois se vincula também ao compromisso epistemológico da professora em contribuir efetivamente para a aprendizagem e desenvolvimento de seus alunos. Neste sentido, ela estava sempre buscando estratégias diversificadas de atuação e formas de intervenção personalizadas. Em alguns momentos, mesmo enfrentando problemas de saúde na família, ela abria mão da possibilidade de ficar de licença médica por pensar no prejuízo que os alunos teriam se ficassem sem aula. Estes aspectos indicam seu comprometimento com os alunos e com o seu papel como professora, o que foi expressado também no complemento de frases:

5- Eu sou determinada e comprometida

27- Esforço-me para superar minhas dificuldades

35- Minhas obrigações comprometimento e responsabilidade

43- Não consigo perder a esperança

Articulado ao comprometimento com o outro e com a docência, a professora apresenta uma autodeterminação e uma orientação ativa para a busca de crescimento pessoal, elementos que constituem sua subjetividade individual e que se expressam tanto na sua prática pedagógica, quanto na sua vida pessoal.

32- Eu sempre posso ser melhor.

63- Tenho dúvidas preciso buscar

21- Desejo ter sabedoria para construir o meu caminho.

Esses elementos se expressam também em seu processo de formação docente. No ano anterior à pesquisa Alice concluiu uma especialização em Educação Infantil, curso que foi 
ofertado pela Universidade de Brasília, em parceria com a Secretaria de Educação do Distrito Federal. No trabalho final do curso, ela realizou uma pesquisa sobre imaginação e emoção em crianças e, como desdobramento, escreveu alguns artigos científicos que foram apresentados em congressos nacionais e internacionais de educação. Alice manifestava alegria e orgulho por participar desses eventos e demonstrava interesse pela continuidade dos estudos através do ingresso no Mestrado. Durante a pesquisa, a professora participou de aulas como aluna especial no programa de pós-graduação em educação da Universidade de Brasília em horário inverso ao de sua regência em sala de aula e em diversos momentos conversávamos sobre os desafios do processo de produção científica. Os trechos a seguir, retirados do complemento de frases e da rede social da professora, ilustram esses aspectos:

\section{1-Minha principal ambição avançar na vida acadêmica.}

"A vida não me cansa, porque amanhã tenho um bocado de ilusões e um sonho doido pra dar certo." Mais um passo importante na minha vida acadêmica. \#cuiba \#endipe (publicação no facebook)

A análise dessas informações nos indica que o desejo de continuidade dos estudos acadêmicos, as vivências em congressos de educação e os sentidos subjetivos relativos às experiências como pesquisadora eram, naquele momento, importantes aspectos da configuração subjetiva envolvida nos processos de formação docente de Alice, que se articula ainda à busca constante por crescimento pessoal, apresentado anteriormente.

Ainda sobre a experiência no curso de especialização, Alice destaca:

Foi a primeira pós que eu fiz, porque eu sempre tive...eu sou muito enjoada (risos). E
aí eu sempre colocava isso que eu não queria pagar pra fazer uma pós a distância,
semipresencial, como tem por aí. Então eu sempre faço questão de fazer, de ter uma
formação que seja mais presencial e que vai influenciar de fato no meu trabalho,
que vai me apresentar algo. Então assim, a pós foi é... foi algo muito válido pra
reafirmar algumas coisas que eu já acreditava e que eu já vinha fazendo uso no meu
trabalho e pra aprender coisas novas também, principalmente em questão das
crianças especiais, porque eu sempre tive aquele negócio assim de tentar me afastar.
Então assim, a pós me encorajou a pegar minha primeira turma de integração
inversa...e no ano seguinte eu peguei a segunda turma. Assim, muitas vezes eu acho
que...por falta de formação mesmo, de você não saber como lidar com aquela criança
e aí você tem o receio, e eu tenho muito essa questão de é...pegar uma criança e não
conseguir desenvolver um trabalho com ela, de respeitar os limites dela...aí essa foi
uma das coisas muito...muito importante da pós. (Entrevista)

A professora destacou o importante papel do curso de Especialização no fortalecimento de sua formação profissional, tanto com a consolidação de práticas que ela já realizava quanto com a possibilidade de novas aprendizagens. Alice reconhece que tinha receio de atuar com alunos com necessidades educacionais especiais e que o contexto do curso de especialização foi um importante aspecto que a encorajou a enfrentar esse desafio. Articulada às vivências no 
curso, se expressa também a determinação da professora, que se demonstra ativa no enfrentamento de situações conflitantes.

Outro aspecto que merece destaque é o fato de Alice se auto definir como "enjoada" por não querer fazer “qualquer" curso de especialização. Na verdade, ela demonstrava ser exigente consigo e com os outros, primando pela qualidade das atividades que participava. A professora apresentava posicionamento crítico sobre a realidade política e socioeconômica do país e, ainda, sobre a desvalorização da educação neste contexto. Suas redes sociais eram repletas de manifestações críticas neste sentido, através da publicação de charges, reportagens e opiniões pessoais. Alice participava das atividades desenvolvidas pelo sindicato dos professores, aderindo a paralisações e, ainda, explicando para os pais e alunos, mesmo estes sendo crianças, os motivos das reivindicações da categoria docente. A seguir, os trechos do complemento de frases complementam essas situações:

17- Fico inconformada injustiças

25- Queria poder mudar as relações sociais

42- Não suporto injustiças!

37- Eu brigo pelo meu direito e pelo direito dos outros.

Articulando as informações apresentadas compreendemos que a criticidade, o engajamento social e o valor dos espaços democráticas eram aspectos que participavam da configuração subjetiva do seu papel como docente. Interessante notar que tais aspectos apareciam em sua atuação pedagógica, a partir do incentivo da criticidade dos alunos e na construção de um espaço democrático na sala de aula.

O comprometimento com seus alunos e com seu papel como docente gerava em Alice momentos de tensão e ansiedade. No complemento de frases esses sentimentos aparecem em diversos trechos:

3- Eu queria saber controlar a minha ansiedade.

7- Sofro quando não alcanço meus objetivos

14- Eu gostaria de ser mais serena.

34- Tentarei conseguir ser menos ansiosa

53- Necessito acalmar o coração em relação a ansiedade

Em dinâmica conversacional, ela nos esclareceu que essa ansiedade se refere ao excesso de preocupação em relação ao desenvolvimento dos alunos, o que ela relata da seguinte forma:

Eu me preocupo muito com as questões das crianças. Lógico, eu tenho um cuidado de não deixar transparecer no meu trabalho, mas...eu fico ansiosa quando eu percebo que a criança ela ainda não está se desenvolvendo da maneira que eu esperava. Por que assim, eu entendo o Bloco como um processo, mas na nossa realidade não é. E aí, essa criança que não conseguiu se desenvolver da forma que o sistema quer muitas vezes ela não vai ter um olhar diferenciado pra ela. Então, isso me frustra muito. E aí eu fico naquela coisa assim de que...eu me pressiono. Eu acho que eu tenho que dar conta. Então eu me cobro muito, muito com isso. [...] É uma coisa que eu preciso 
trabalhar, eu venho trabalhando, eu tenho essa percepção. (Dinâmica conversacional)

Na preocupação da professora Alice aparece ainda uma crítica à forma como muitos docentes concebem o Bloco Inicial de Alfabetização que, apesar de ser pensado como um ciclo em que os alunos têm um tempo maior para serem alfabetizados e que a instituição escolar deve criar mecanismos para que isso ocorra, na prática percebemos que em muitas escolas não é isso que acontece. Dessa forma, ao se preocupar com os anos seguintes dos alunos que estão enfrentando algum tipo de dificuldade no processo de alfabetização e com a possibilidade desses alunos não receberem a ajuda necessária à continuidade da sua aprendizagem e desenvolvimento, Alice enfrenta sentimentos de tensão e ansiedade associados à auto cobrança.

No conselho de classe do segundo bimestre, a professora manifestou essa ansiedade em relação a três alunos que, apesar de terem apresentado muitos avanços em outras áreas, demonstravam poucos progressos no processo de aprendizagem da leitura e escrita. Na ocasião, Alice disse que não sabia identificar se isso era devido ao tempo das crianças ou se era alguma inadequação no trabalho que ela estava desenvolvendo. Ela então sugeriu que algum outro profissional, como a orientadora pedagógica ou a psicóloga, pudesse observar suas aulas para que juntas pensassem em alternativas para lidar com as necessidades daquelas crianças. Entretanto, dois meses após o conselho de classe, em dinâmica conversacional Alice relatou que nada foi feito.

Eu tenho que pensar nessas duas possibilidades, que seja o tempo deles ou que seja alguma falha, algum direcionamento que eu esteja dando. É muito complicado por que assim eu costumo me avaliar diariamente, às vezes até dentro da sala. [...] Mas assim, você tem a resposta das crianças, você tem a resposta das famílias, mas eu acho que você também precisa da resposta de um profissional da educação especificamente. E isso a gente não tem, você entra pra sua sala e você acaba ficando solitário. (Dinâmica conversacional)

Ainda sobre o apoio da escola no desenvolvimento do seu trabalho pedagógico ela destaca:

Recursos materiais eu nunca vou poder reclamar, por que tudo que eu peço, se não tem na escola sempre é providenciado. Mas é...o pedagógico da escola não funciona. Os professores trabalham por si só. Tanto que a gente não tem a figura de um Supervisor Pedagógico. Acho que em algum momento isso não foi dado como importante, porque optou-se pelo supervisor administrativo e ninguém assumiu essa responsabilidade. (Dinâmica conversacional)

Pela quantidade de alunos a escola em questão poderia ter até três coordenadores pedagógicos, entretanto, devido à falta de interesse dos professores em assumir tal cargo, a escola possuía apenas uma coordenadora. Além disso, a escola não tinha um Supervisor 
Pedagógico e, sem alguém que fizesse esse papel de articulação e orientação do trabalho pedagógico, cada professor atuava da maneira que achava mais conveniente, não havia um trabalho coletivo. Neste contexto, Alice trocava ideias e experiências com algumas colegas com quem tinha mais afinidade, mas sentia falta de um apoio mais sistematizado. Dessa forma, ela tomou iniciativas pessoais para o enfrentamento dessa dificuldade.

Depois que eu pedi ajuda um bimestre se passou e nada aconteceu. Mas aí eu fui
buscar em outro lugar, que é uma amiga que eu tenho, que é uma pessoa que eu
aprendi muito, de outra escola. E aí eu fui até ela e disse "tô precisando conversar,
me socorre, me orienta" e aí ela me ajuda a acalmar minha ansiedade por que ela
diz "Alice, tem coisa que você não pode fazer" e isso eu tenho dificuldade, é uma
coisa que eu ainda preciso aceitar. E também a gente pensou em outras atividades,
as crianças elas começaram a fazer reforço comigo, elas cresceram. Já tô vendo
muitos avanços, nossa, elas já cresceram bastante. (Dinâmica conversacional)

A partir dessas informações destacamos que para Alice a figura do outro aparece como importante apoio para o enfrentamento das tensões e ansiedades relacionadas às suas preocupações com o desenvolvimento dos alunos. A importância do outro no desenvolvimento do seu trabalho aparece ainda em outras situações, como na busca por parcerias de outros profissionais por quem Alice tem admiração e reconhecimento. Para exemplificar podemos citar o desenvolvimento de atividades junto à professora da Sala de Recursos, a contação de histórias com uma professora do $2^{\circ}$ ano e o convite a professoras intérpretes de Libras, de outra escola, para visitar sua turma.

Compreendemos que a importância das parcerias e do trabalho coletivo não se configura apenas como um apoio operacional no desenvolvimento do trabalho pedagógico de Alice, mas aparece configurado subjetivamente articulado às possibilidades de aprendizagem e crescimento pessoal com o outro. Para fortalecer esta interpretação destacamos a seguir dois trechos retirados de sua rede social, uma sobre sua relação com a orientadora do curso de especialização e outra sobre uma atividade realizada na sala de aula em parceria com outras profissionais.

\footnotetext{
Algumas pessoas tem uma orientadora em seu percurso acadêmico, eu fui presenteada com uma grande amiga! Saber que existem pessoas que te incentivam a crescer intelectualmente é o que de mais fantástico pode nos acontecer. \#pormaispessoasassim (publicação no facebook)

E hoje a nossa tarde foi mais que especial. Recebemos a visita de duas excelentes profissionais que são apaixonadas pelo que fazem e duas crianças surdas que se dispuseram a responder as perguntas dessa turminha linda. Brincamos, cantamos e compartilhamos saberes e curiosidades! Gratidão! Adoramos o momento! (publicação no facebook)
}

Alice demonstrava valorizar as relações pessoais e profissionais com pessoas que julgava ser responsáveis e comprometidos com o que fazem. Conviver e trocar experiências com pessoas que ela admira profissionalmente significava para ela a possibilidade de 
crescimento pessoal e profissional. Dessa maneira, as relações com os profissionais da área da educação retroalimentavam seu desenvolvimento como docente e constituíam seu trabalho pedagógico.

Outro ponto que merece destaque é o fato de Alice buscar por iniciativa própria a parceria com outros profissionais da educação, mesmo fora da escola em que trabalhava. $O$ fato de não encontrar esse apoio pedagógico de maneira sistematizada numa figura que assuma uma função específica na escola em que atuava gerava em Alice uma atitude de criticidade e de busca pessoal para o enfrentamento dessas questões.

Ainda sobre o apoio da escola em relação a seu trabalho pedagógico Alice destacou que em algumas situações específicas houve propostas de projetos, como foi o caso da Semana da Inclusão. Nestas ocasiões, ela participava dando sugestões e adequando à realidade da sua turma.

Ano passado a gente tinha uma supervisora pedagógica e já teve vezes que os projetos vieram de cima pra baixo. E eu tenho dificuldade de aceitar isso, de cima pra baixo, por que eu tenho a minha turma, tenho a realidade da minha turma, como que alguém vai montar um projeto pra eu aplicar na minha turma sem conhecer essa realidade? $[\ldots]$

Assim, eu tento dar a minha cara pr'aquele projeto, eu tento sentar com as crianças, mas elas não ficam sem participar. (Dinâmica Conversacional)

$\mathrm{O}$ trecho destacado articulado às informações anteriores que demonstram o posicionamento ativo, o comprometimento, a autoria na elaboração de atividades e estratégias pedagógicas, o enfrentamento das tensões e a constante busca por crescimento pessoal evidenciam a expressão da sua condição de sujeito no trabalho pedagógico.

A despeito de reconhecermos que o professor deve ser ativo em sua prática e buscar recursos pessoais e subjetivos para o enfrentamento das adversidades, não podemos deixar de discutir o papel da equipe gestora e da coordenação pedagógica nesse processo. Entendemos que as tensões, ansiedades e dificuldades que o professor enfrenta no cotidiano do contexto pedagógico deveriam ser abordadas na coordenação pedagógica, no sentido de ter uma articulação entre os profissionais para garantir um trabalho coletivo na superação dos desafios encontrados e, ainda, de continuidade do atendimento personalizado de acordo com as necessidades e singularidades das crianças, afinal o aluno não é responsabilidade apenas da professora da turma, mas de toda a escola. Entretanto, esse tipo de abordagem tem sido um desafio nas escolas públicas devido, entre outras questões, à ausência de uma figura que assuma o direcionamento pedagógico das escolas, seja por desinteresse das pessoas em assumir o cargo, seja por dificuldades de o coordenador assumir funções exclusivamente pedagógicas dadas às diversas demandas do contexto escolar. Há que se debater essa situação e pensar em estratégias 
para que o espaço da coordenação pedagógica se torne efetivamente um espaço de formação, que impliquem subjetivamente o professor no desenvolvimento do seu trabalho pedagógico e garantam a aprendizagem e o desenvolvimento dos alunos.

\subsection{Síntese integrativa dos aspectos analisados: respondendo aos objetivos da pesquisa}

A construção interpretativa constitui a proposição de respostas aos objetivos da pesquisa, bem como a reflexão das contribuições deste estudo. Compreendendo a importância de os professores considerarem a singularidades dos alunos na sala de aula nos propomos a investigar de que formas a professora Alice buscava conhecer as especificidades de seus alunos. Neste sentido, foi necessário analisar as bases que constituíam a relação entre a professora e os alunos, assim como conhecer aspectos da constituição da subjetividade individual da professora. Estes tópicos, apresentados anteriormente, nos ajudaram a vislumbrar a multiplicidade de aspectos que constituem a dinâmica relacional da sala de aula. A título de síntese, consideramos bastante representativa a redação elaborada pela professora (apêndice E) em forma de cordel. Este instrumento foi proposto após cinco meses de pesquisa e nos possibilitou voltar aos instrumentos anteriores para consolidar indicadores levantados anteriormente.

Vou dedicar este cordel

A uma turma especial

Balão mágico é o nome Dessa classe sensacional Que tem à frente a Tia Alice

Partilhando uma aventura sem igual

A aventura do saber acontecendo

Neste ano de aprendizagem encantada

Despertando a imaginação e emoção

Com a magia dos contos de fadas

Trabalhando a sensibilidade artística

E demais talentos desta criançada

E neste ambiente encantado

A democracia não pode faltar

E é nas rodas de conversa

Que os protestos começam a brotar

Afinal são crianças críticas

Que estão a se formar.

Mas não é só o intelecto

Que está sendo desenvolvido

Não esqueçamos que o corpo

Precisa estar bem nutrido 
Com as receitas e aulas de comidinha

Se alimentar nunca foi tão divertido

E por falar em diversão

Muitas atividades devemos citar

Casinha, miniaturas, faz de conta,

Construção e massinhas de modelar

Tudo sendo feito em grupo

No momento mágico do brincar

E pra encerrar este cordel

Um momento de pura emoção

"Tia, eu posso te amar?"

Pergunta vinda do coração

É a inocência a nos apontar

Que educar com afeto é a direção.

O cordel representa uma opção criativa da professora Alice, repleta de sentidos subjetivos em relação a sua turma. $\mathrm{O}$ texto nos apresenta a reunião de alguns aspectos que compreendemos estar na base da dinâmica relacional que foi construída naquela sala de aula, tais como: o vínculo emocional da professora com a turma; a compreensão da importância da imaginação, da emoção e das brincadeiras no desenvolvimento infantil; o entendimento de que a aprendizagem deve ser prazerosa e de que o aluno deve ter uma formação crítica; e uma produção de sentidos subjetivos de alegria e emoção em relação às manifestações de afeto dos seus alunos. Estes aspectos, juntamente com os outros que foram destacados anteriormente, são princípios do trabalho pedagógico da professora Alice e dos modos como ela percebe seus alunos e busca construir relações com os mesmos. Por sua vez, percebemos a articulação desses princípios com a constituição da subjetividade individual da professora, especialmente seu caráter ativo e comprometido com sua formação pessoal e profissional e com o desenvolvimento de seus alunos.

Quando falamos em relação não podemos ter o foco em apenas um lado ou um sujeito, entretanto pela posição que o professor ocupa como organizador do ambiente social e pela sua intencionalidade, entendemos que sua constituição subjetiva tem implicações para os modos como ele busca se colocar perante e com os alunos. Especificamente no contexto da pesquisa, reconhecemos o papel central da professora Alice para o modo de funcionamento da turma. Compreendemos que a maneira como o trabalho pedagógico era organizado pela professora Alice propiciava a construção de espaços relacionais de modo que ela criava várias oportunidades de conhecer seus alunos e se aproximar deles. As atividades realizadas no Projeto Gente têm nome e sobrenome, o acompanhamento individualizado, a constante alternância entre os momentos coletivos e individuais, os momentos dedicados às rodas de conversa e a abertura às falas e expressões espontâneas dos alunos são exemplos de estratégias neste sentido. 
Ao propormos a pesquisa, o objetivo central era investigar as maneiras como a professora buscava conhecer as especificidades de seus alunos na sala de aula e como integrava esses aspectos à organização do trabalho pedagógico. Nos primeiros contatos com a turma, identificamos algumas estratégias que auxiliavam a professora neste processo e destacamos o projeto "Gente tem nome e sobrenome", pois permitia, para além do desenvolvimento da construção da leitura e escrita, que a docente tivesse acesso a aspectos da vida de cada aluno, tais como conhecimento sobre os hábitos familiares, gostos, interesses e história de vida. A princípio, levantamos a hipótese de que este projeto era a estratégia principal da professora para conhecer seus alunos, sendo assim uma "resposta" ao objetivo geral da pesquisa. Entretanto, no decorrer da investigação percebemos que, apesar de ser uma estratégia bastante interessante, o projeto era apenas mais um aspecto que compunha a dinâmica daquela turma. $\mathrm{O}$ diferencial não estava nas estratégias instrumentais e operacionais criadas pela professora, mas na maneira em como estas eram desenvolvidas e constituíam um modo singular de funcionamento da turma que estava organizado articulado à configuração subjetiva da professora, participando dessa organização como sistema.

O valor dessas estratégias estava na criação de canais comunicativos que perpassava todas elas. O diálogo estava na base de todas as atividades que eram desenvolvidas na sala de aula e a dinâmica que foi se estabelecendo naquele espaço social - em que os alunos eram respeitados e valorizados em suas singularidades, em que havia uma rotina organizada e um compromisso mútuo no cumprimento dos acordos - propiciava que as crianças se mostrassem por inteiro. O espaço dialógico e a liberdade de expressão dos alunos eram características daquela turma que iam se configurando em elementos de sentido de maneira muito singular, integrando a subjetividade social daquela sala de aula. Ou seja, as formas como a professora buscava conhecer seus alunos não estavam baseadas em uma ação, mas na transformação da sala de aula como um espaço relacional. A relação dialógica entre professora e alunos era base para o desenvolvimento do trabalho pedagógico e, ainda, para o desenvolvimento dos alunos e da própria professora.

As relações dialógicas estavam na base de todo o trabalho pedagógico da professora Alice. Não havia apenas um momento formal específico para que ela buscasse conhecer as especificidades dos alunos, mas todo o modo de funcionamento da turma e os modos como a professora se colocava favoreciam sua aproximação com as crianças, de forma que isto acontecia de maneira natural. Além disso, a professora Alice conseguia integrar na organização do trabalho pedagógico aspectos que ela percebia no momento relacional, seja com um aluno 
específico ou com toda a turma. Assim, ela reorganizava o trabalho pedagógico a partir do olhar das crianças.

A partir dessas interpretações, consideramos importante destacar que é fundamental que o professor crie estratégias que permitam sua aproximação com os alunos e o conhecimento dos mesmos de maneira mais ampla e complexa, no entanto, tão relevante quanto planejar estratégias é o professor reconhecer situações, no momento da ação, em que possa ir ao encontro dos alunos, especialmente aqueles que estão apresentando alguma dificuldade no contexto escolar. Tão importante quanto planejar situações de aprendizagem é reconhecer as situações de aprendizagem e desenvolvimento, e estas podem acontecer nos mais diversos momentos na sala de aula, inclusive os informais.

A relação dialógica não é apenas a relação onde há diálogo, mas a relação que apresenta uma abertura humana para o encontro e que possibilita uma produção subjetiva que desenvolva a relação em curso. O momento do diálogo entre um professor e um aluno, por exemplo, não é apenas a soma das duas pessoas, mas a produção de um novo campo relacional. Durante o diálogo e na relação, coisas novas são produzidas. Não é só uma troca de ideias, há um caminho de infinitas possibilidades, que nem mesmo o professor com sua intencionalidade tem controle. A relação dialógica se alimenta no curso da ação e tem um caráter gerador que pode implicar em novos processos de subjetivação que irão integrar a configuração subjetiva do aluno, por exemplo, facilitando seu envolvimento com a aprendizagem.

O protagonismo dos alunos na sala de aula se articulava com escolhas pedagógicas da professora, que por sua vez, eram regidas por princípios próprios que envolviam seus processos formativos, suas concepções e produções subjetivas. Não se trata aqui de buscar modelos ou receitas de práticas pedagógicas de sucesso, mas em se problematizar a necessidade de a organização do trabalho pedagógico, bem como das relações sociais que são construídas na sala de aula, possibilitarem a abertura de espaço para que o outro se posicione como sujeito.

Bezerra (2016, p. 56) destaca que pensar a dimensão subjetiva da relação professoraluno significa redimensionar o papel do professor que deve se configurar como um "outro social" que "só existe inserido numa sequência histórica de relações, que vai se transformando em um sistema de sentido, a partir do qual este outro passa a ter significação no desenvolvimento da criança". A sala de aula se configura como espaço relacional dialógico em que alunos e professores vivenciam experiências que serão configuradas subjetivamente. Assim, o modo de funcionamento de uma turma deve se caracterizar como processo de desenvolvimento subjetivo, onde o professor reconheça e considere os diferentes modos de organização subjetiva das crianças em seu processo de aprendizagem e desenvolvimento. 
No contexto investigado, destacamos o papel central da professora na personalização do ensino e do clima comunicativo-emocional (MITJÁNS MARTINEZ, 2006) que contribuiu para a caracterização da sala de aula como espaço potencial de sentidos subjetivos mobilizadores do maior envolvimento entre professora e alunos e entre os alunos e seus processos de aprendizagem.

Diante dessa complexidade algumas pessoas podem questionar: cabe ao professor aprofundar nas questões subjetivas de cada aluno? O professor tem condições de investigar a constituição subjetiva de todos os alunos? Estamos buscando uma perspectiva clínica do trabalho do professor ou ainda uma aplicabilidade da Teoria da Subjetividade na prática pedagógica? Há que se refletir sobre tais questões com cuidado.

Não podemos falar de aplicabilidade da teoria na prática, visto que isto contradiz o que a própria Teoria da Subjetividade sustenta. Entretanto, aprofundar o entendimento sobre a subjetividade humana abre novas zonas de sentido para se pensar o desenvolvimento humano e os processos educativos. Não se trata de uma perspectiva clínica do trabalho do professor, mas de ele compreender que precisa olhar para o aluno de uma maneira mais ampla e complexa e buscar criar possibilidades para a aprendizagem e desenvolvimento de todos, especialmente aqueles que vêm enfrentando barreiras no processo escolar. Este processo torna-se complexo se pensarmos que envolve a subjetividade social da escola e da sociedade de maneira mais ampla sobre o papel da educação e o papel do professor, em articulação com a subjetividade individual do próprio professor. O professor é visto como executor de tarefas ou como produtor? Na subjetividade social da escola se entende o trabalho do professor como técnica? O professor entende o desenvolvimento como algo processual, inacabado ou estanque? Se pensa as práticas pedagógicas como práticas dialógicas ou como transmissão de conteúdos? Todos esses entendimentos estão por trás da maneira como o professor percebe seu aluno e se articulam de maneira complexa na produção de sentidos subjetivos sobre o aluno, bem como na constituição subjetiva da sala de aula. Entretanto, a maneira como o professor percebe seus alunos também é um processo que se desenvolve. No curso da ação, na relação com as crianças o professor pode produzir novos processos de subjetivação que implicam num novo posicionamento como docente e na criação de recursos para se aproximar ou se afastar de determinado aluno, por exemplo.

Recordamos neste momento a fala de uma professora, desta mesma escola investigada, durante um conselho de classe. Ela se queixava de um aluno que perturbava a ordem da sala de aula, mexendo com os colegas, desafiando a professora, sempre emburrado e de cara fechada se recusava a fazer qualquer tipo de atividade. A professora disse que percebia que estava 
começando a "implicar" com aquele aluno e que já parava de investir em sua aprendizagem, já que isso demandava tamanha energia dela. Continuando o relato, a professora contou que em um dia de recreação aquele aluno brincava muito, se divertia, sorria bastante e se apresentava de uma maneira descontraída muito diversa da maneira que se posicionava em sala de aula. Naquele instante a professora disse que olhou pra ele de uma outra maneira, que ver a alegria que ele expressava brincando fez ela pensar: "ele é só uma criança!". A partir de então, a professora disse que tentava olhar para ele com mais leveza, entendendo que ele não era apenas "o menino que perturbava a sala", mas que podia ser também o menino alegre do dia da recreação.

Este relato simples e, ao mesmo tempo, profundo nos mostra o quão complexa é a relação entre professor e alunos. A maneira como o professor enxerga os alunos pode implicar no investimento que o docente fará em sua aprendizagem. Será que a professora do relato precisaria investigar questões mais específicas da constituição subjetiva de todos os seus alunos? Provavelmente não, mas em relação àquele aluno específico ela possivelmente precisaria buscar uma aproximação no sentido de entender o que está por trás daqueles comportamentos que atrapalham a relação do aluno com o contexto de aprendizagem. Para isso, ela precisaria conhecer a Teoria da Subjetividade? Não necessariamente. O relato já nos mostra que a professora conseguiu perceber o aluno de outra forma e tentou não cristalizar a imagem anterior. Os próximos passos, a forma de trabalhar com aquela criança ou qualquer outra, será descoberta na relação. O professor deverá pensar em como abre espaço para as crianças se posicionarem na sala de aula, e não apenas seus pensamentos sobre os conteúdos curriculares, mas a partir de seus interesses, gostos, contextos sociais, emocionalidades, etc. O professor deverá buscar formas para que o outro se expresse e se posicione como sujeito de sua aprendizagem e desenvolvimento e, tal processo só será possível a partir de uma implicação simbólico-emocional. Este processo é desafiador porque não está em um manual, em um livro ou até mesmo na teoria, ele será descoberto e construído na relação dialógica com o outro. Qual é a qualidade da relação que gera diferença na prática pedagógica? Não é apenas o vínculo afetivo piegas, mas a relação que gera um espaço comunicativo-emocional entre as pessoas. Um ambiente em que a criança sinta-se livre para se posicionar ao mesmo tempo em que o professor instigue, tencione, provoque e faça uma boa leitura interpretativa da criança.

É importante destacar que a Teoria da Subjetividade se apresenta como possibilidade de compreensão de fenômenos complexos, tais como os processos relacionais no contexto pedagógico. Compreender a relação entre professor e alunos a partir de sua complexidade não significa apenas ponderar que é algo complicado ou de difícil explicação, mas principalmente 
considerar como um processo que possui formas de organização plurideterminadas e sistêmicas. Como esclarece González Rey (2005, p. 18), “a complexidade expressa uma tensão constante entre organização e processo, entre continuidade e ruptura, que rompe com o determinismo mecanicista.” Dessa forma, os fenômenos complexos exigem leituras plurais, com reconhecimento da sua heterogeneidade constitutiva, seu caráter histórico, singular e indivisível em elementos fragmentados (MITJÁNS MARTINEZ, 2005). 


\section{CONSIDERAÇÕES FINAIS}

Neste trabalho procuramos discutir a importância da transformação da sala de aula em um espaço relacional a partir da investigação dos modos como uma professora buscava conhecer as especificidades de seus alunos no contexto pedagógico e, ainda, como a docente articulava esse conhecimento à organização do trabalho pedagógico. Para isso, tivemos que imergir no espaço social da sala de aula e da escola para construir o maior envolvimento possível com a turma e a professora participante da pesquisa. Conhecemos as formas de relação entre professora e alunos, os modos como a professora realizava suas escolhas pedagógicas, suas crenças e valores sobre ensinar e aprender e o modo de funcionamento que foi se desenvolvendo na turma.

Na Epistemologia Qualitativa a tensão entre momento empírico e teórico é constante e sustenta os indicadores levantados que definirão os próximos rumos da investigação, bem como o modelo teórico construído. Compreender os princípios que estavam na base das formas de relação entre a professora e os alunos demandou um grande esforço científico e foi um desafio instigante, pois traziam múltiplos aspectos para análise. Dessa forma, a sistematização escrita do processo construtivo interpretativo foi um processo difícil pela impossibilidade de separar esses aspectos que, na maioria das vezes, estavam bastante articulados. Assim, decidimos apresentar os princípios da relação professora-alunos da turma investigada a partir dos seguintes tópicos: clima da sala de aula; concepção da professora sobre o processo de aprendizagem; encantamento com a infância; alunos como sujeitos protagonistas de seus processos de aprendizagem e desenvolvimento; individualização da relação/olhar para o sujeito; importância da imaginação e emoção no desenvolvimento infantil; envolvimento emocional como base das relações; comunicação com os pais. Ao fazer esta escolha, tínhamos a consciência de que alguns desses tópicos estavam mais relacionados ao sistema de crenças e valores da professora, outros mais relacionados ao desenvolvimento da relação na sala de aula e outros mais relacionados às definições do trabalho pedagógico. Ainda assim, optamos por não fazer tal separação, pois estes aspectos estavam articulados de maneira complexa, constituindo um modo singular de funcionamento da turma.

Consideramos que este fato, que representou uma dificuldade no processo de sistematização, é, simultaneamente, uma contribuição da pesquisa, pois evidencia a multiplicidade de aspectos que constituem a relação professor-aluno e a complexidade desse processo. Dessa forma, não se pode reduzir a análise desse tema a expressões comportamentais de professores e alunos, como já discutido na revisão de literatura. Há que se discutir o tema a 
partir de uma representação sistêmica dos processos psicológicos, compreendendo seu caráter processual e dinâmico que se organiza nos indivíduos e nos espaços sociais.

Reconhecendo a complexidade da relação professor-aluno na sala de aula, em seu caráter "desordenado, contraditório, plural, recursivo, singular, indivisível e histórico" (MITJÁNS MARTINEZ, 2005) consideramos que esta pesquisa pôde trazer as seguintes contribuições:

- O desenvolvimento da pesquisa a partir do referencial teórico da teoria da subjetividade numa perspectiva cultural-histórica possibilitou-nos o reconhecimento da dimensão subjetiva que constitui a relação entre professor e alunos e o modo de funcionamento de uma turma. Esta dimensão muitas vezes é negada nas práticas pedagógicas ou reduzida à afetividade considerada de maneira piegas. Reconhecer esta dimensão subjetiva não significa considerar que é mais um elemento que compõe a relação professor-aluno, mas ponderar que a ação pedagógica se concretiza em um conjunto de vivências relacionais e que estas vivências são configuradas de maneira singular em cada sujeito;

- O entendimento de que o professor tem papel central no desenvolvimento da relação com os alunos, por sua intencionalidade e função como organizador do espaço social da sala de aula traz à tona a importância de se discutir a constituição da subjetividade individual dos professores, pois suas escolhas pedagógicas nunca estarão desvinculadas de tal constituição subjetiva;

- A consideração de que, apesar de estar fortemente marcada pela constituição subjetiva do docente, a relação entre professor e alunos é um espaço aberto, de múltiplas possibilidades, impossível de controle e previsibilidade, que pode gerar processos emocionais e simbólicos que retroalimentam as práticas pedagógicas e o próprio desenvolvimento dos processos relacionais;

- O reconhecimento da necessidade de os professores buscarem conhecer a singularidade dos alunos - entendida como realidade subjetiva do outro - criando situações que permitam o acesso a seus posicionamentos, reflexões, dificuldades, emocionalidades, de modo a gerar contextos potencializadores de aprendizagem e desenvolvimento, em que os sujeitos que aprendem se reconheçam no espaço social no qual participam;

- A compreensão de que o clima comunicativo-emocional da sala de aula constitui fortemente a coletividade da turma, onde os alunos irão produzir sentidos subjetivos que implicam no seu envolvimento ativo e emocional com as atividades pedagógicas. A produção de sentidos subjetivos não tem relação direta com o posicionamento da 
professora, pois integra aspectos da história de vida dos sujeitos e aspectos dos outros contextos sociais que eles participam, entretanto, a qualidade das relações pedagógicas pode abrir espaço para novos processos de subjetivação que implique no desenvolvimento das crianças;

- A consideração da importância da relação dialógica, entendida para além do diálogo, como a produção de um novo campo de infinitas possibilidades que se alimentam no curso da ação e tem um caráter gerador que implica processos de subjetivação que irão integrar a configuração subjetiva tanto dos alunos, como do professor, além da subjetividade social da sala de aula.

Estas contribuições trazem o desafio de se repensar a escola da maneira como ela está estruturada e organizada, bem como a subjetividade social sobre ensinar e aprender. No contexto da pesquisa, identificamos que a professora conseguia transformar sua sala de aula em um espaço relacional, a partir de um olhar voltado para os sujeitos e da criação constante de recursos relacionais e estratégias próximas às necessidades e especificidades de seus alunos. Entretanto, esta mesma professora reconhece que em turmas mais avançadas seria complicado criar esse contexto relacional, pelas exigências curriculares e pelas exigências dos próprios pais e profissionais da educação. Há que se ampliar a discussão para outros contextos e se avançar propondo mudanças especialmente nos modos de conceber a aprendizagem e a educação, que precisa sim possibilitar a transmissão dos conteúdos culturais, mas mais do que isso, o desenvolvimento das pessoas.

Destacamos, ainda, que a pesquisa pode contribuir para a formação inicial e continuada de professores a partir da conscientização da importância das relações entre professor e alunos para a transformação da sala de aula num espaço de aprendizagem e desenvolvimento. Além de professores, é fundamental que psicólogos escolares também participem desse debate. Ademais, o modo de funcionamento da turma participante da pesquisa nos permite discutir que é possível sim criar um ambiente relacional e participativo, mesmo com as dificuldades estruturais das instituições educativas.

Ainda, consideramos como contribuição o conhecimento da pesquisa por gestores e equipes pedagógicas no sentido de pensar em como práticas criativas e diferenciadas, como a apresentada pela professora Alice, podem tomar mais visibilidade na escola como um todo atingindo uma coletividade, de modo que a própria escola se transforme em contexto de formação continuada. 
Para além das contribuições, destacamos que a pesquisa possui também limitações que se relacionam ao próprio objetivo elencado e ao tempo de investigação. Nesta pesquisa investigamos os princípios que estavam na base da relação entre professora e alunos, as estratégias da professora para conhecer seus alunos e aspectos da constituição subjetiva da professora. Devido a esta definição e pelo tempo da pesquisa, não investigamos as maneiras como este contexto relacional eram configuradas subjetivamente pelos alunos da turma. Tivemos algumas situações que possibilitaram o levantamento de indicadores, no entanto não foi possível adentrar neste tema de forma mais densa. Destacamos que tal limitação se relaciona à organização do percurso acadêmico e reconhecemos esse tema como desdobramento e possibilidade de investigações futuras. Nesta perspectiva, indicamos ainda a possibilidade de investigações futuras sobre a relação professor-alunos em contextos de outros níveis de ensino e salientamos a necessidade das próximas investigações superarem o caráter descritivo e buscar bases epistemológicas mais explicativas e contemplem a complexidade do tema.

Por fim, vale destacar a importância do percurso acadêmico que culminou nesta pesquisa para minha constituição como investigadora, além do meu crescimento pessoal, aspectos estes que integram minha constituição subjetiva como docente. A proximidade com uma nova perspectiva epistemológica e o recente contato com a teoria da subjetividade gerou processos desafiadores e de enfrentamento pessoal, especialmente no desenvolvimento de um papel ativo como pesquisadora e estudante. Neste sentido, destacamos a produtividade desse processo de pesquisa por possibilitar o enfrentamento pessoal e a constituição como pesquisadora e profissional. 


\section{REFERÊNCIAS}

ANDRADA, Luana Pimenta de. O professor na psicologia histórico-cultural: da mediação à relação pedagógica. 2006. 160 f. Dissertação (Mestrado em Educação)-Universidade de Brasília, Brasília, 2006.

ANJOS, Noélia Martins dos. A escola como contexto de desenvolvimento humano: possibilidades da prática docente. 2014. 166 f. Dissertação (Mestrado em Educação)— Universidade de Brasília, Brasília, 2014.

BARBOSA, Altemir José Gonçalves; CAMPOS, Renata Araújo; VALENTIM, Tássia Azevedo. A diversidade em sala de aula e a relação professor-aluno. Estud. psicol. (Campinas), Campinas, v. 28, n. 4, p. 453-461, dez 2011.

BARRIOS GONZÁLEZ, Alia Maria. Diálogo ou heteronomia no ensino fundamental?: desenvolvimento moral, cultura e práticas educativas. Tese (Doutorado em Processos de Desenvolvimento Humano e Saúde). Universidade de Brasília, 2013.

BENTO, Maria Cristina M.; SANTOS, Isabela Gomes da S. I., Atitudes do professor em sala de aula - um estudo. Educação, Cultura e Comunicação, v. 5, n. 9, 2014.

BEZERRA, Marília dos Santos. Subjetividade e aprendizagem: o papel da relação professoraluno e seus desdobramentos para o processo de ensino-aprendizagem. In.: GOULAR, Daniel M.; ALCÂNTARA, Raquel de (Orgs.). Educação escolar e subjetividade: desafios contemporâneos. Global South, 2016.

CAMPOS, G. R. A. A Constituição subjetiva do aluno em situação de fracasso escolar. (Dissertação de Mestrado). Brasília: UnB, 2005

CASTRO, Paula Almeida de. O estigma no espaço escolar: a prática dos conselhos de classe. Revista Reflexão e Ação, Santa Cruz do Sul, v. 19, n. 2, p.158-172, jul./dez. 2011.

CRUZ, Marney Eduardo Ferreira. A inter-relação entre professores e universitários à luz da subjetividade. 2009. 120 f. Dissertação (Mestrado em Educação)-Universidade de Brasília, Brasília, 2009.

DISTRITO FEDERAL. Secretaria de Estado e Educação do Distrito Federal. Orientação pedagógica da Educação Especial. Brasília, 2010.

FARIAS ET AL, Maria Sabino de. Didática e docência: aprendendo a profissão. Fortaleza: Liber Livro, 2008.

FERREIRA, Ana Tereza Ramos de Jesus. O brincar como possibilidade do professor conhecer os processos de aprender e pensar dos alunos que enfretam obstáculos no processo de aprendizagem. 2013. xii, 126 f., il. Dissertação (Mestrado em Educação) Universidade de Brasília, Brasília, 2013. 
GONZÁLEZ REY, Fernando Luis. La comunicación educativa: su importancia en el desarrollo integral de la personalidad. Comunicación, personalidad y desarrollo. Ed. Pueblo y Educación. La Habana, Cuba, 1999.

Pesquisa qualitativa na psicologia: caminhos e desafios. São Paulo: Pioneira Thomson Learning, 2002.

Sujeito e subjetividade: uma aproximação histórico-cultural. São Paulo: Pioneira Thomson Learning, 2003.

Pesquisa qualitativa e subjetividade: os processos de construção da informação. São Paulo: Cengage Learning, 2005.

O sujeito que aprende: desafios do desenvolvimento do tema da aprendizagem na Psicologia e na prática pedagógica. In.: Aprendizagem e Trabalho Pedagógico. Carmem Tacca (Org.). Campinas, SP: Alínea, 2006.

Subjetividade e saúde: superando a clínica da patologia.

São Paulo: Cortez, 2011.

O pensamento de Vigotsky: contradições, desdobramentos e desenvolvimento. São Paulo, Hucitec: 2012a.

.O social na psicologia e a psicologia social: a emergência do sujeito. $3^{\mathrm{a}}$ ed.Petrópolis, RJ: Vozes, 2012 b.

LAMAS, Karen C. Alves; FREITAS, Eduarda Rezende; BARBOSA, Altamir J. G. Bullyng e relação professor-aluno: percepções de estudantes do Ensino Fundamental. Psico (PUCRS), v. 44, n. 2, pp. 263-272, abr./jun. 2013.

LIBÓRIO, Ana Clara Oliveira. As interações professor-aluno e o clima para criatividade em sala de aula: possíveis relações. Dissertação (Mestrado em Processos do Desenvolvimento Humano e Saúde). Universidade de Brasília, 2009.

LIMA, Helen Tatiana dos Santos. Investigação dos processos de aprendizagem: contribuições para uma intervenção pedagógica no âmbito das relações sociais. 2008. 233 f. Dissertação (Mestrado em Educação)-Universidade de Brasília, Brasília, 2008.

LUNARDI-MENDES, Geovana M. Nas trilhas da exclusão: as práticas curriculares no atendimento as diferenças dos alunos. 2005. Tese (Doutorado em Educação) - Universidade do Estado de Santa Catarina, Florianópolis, 2005.

MADEIRA-COELHO, C. M. Sujeito, Linguagem e Aprendizagem, IN: MITJÁNS MARTÍNEZ, A.; TACCA, M. C. V. R. (orgs), A complexidade da aprendizagem: destaque ao ensino superior, Campinas, SP: Alínea, 2009.

MARTINELLI, Selma de Cássia; SCHIAVONI, Andreza. Percepção do aluno sobre sua interação com o professor e status sociométrico. Estud. psicol. (Campinas), Campinas, v. 26, n. 3, p. 327-336, Sept. 2009. 
MCDERMOTT, R. P. Social relation as contexts for learning in school. Harvard University Review, 47, 1977.

MIRANDA, Simão de. A construção da auto-estima na sala de aula: comunicação e metacomunicação nas interações professora-alunos. Tese (Doutorado em Psicologia)Universidade de Brasília, 2008.

MITJÁNS MARTÍNEZ, A. M. A teoria da subjetividade de González Rey: uma expressão do paradigma da complexidade na psicologia. In.: GONZÁLEZ REY, Fernando Luis (Org.).

Subjetividade, complexidade e pesquisa em psicologia. São Paulo: Pioneira Thomson Learning, 2005.

A perspectiva histórico-cultural da subjetividade: sua significação para o trabalho pedagógico com alunos deficientes. In:ALDA, M. M. S. et al. Novas subjetividades, Currículo, Docência e Questões Pedagógicas na Perspectiva da Inclusão Social. Recife: Edições Bagaço, 2006.

Aprendizagem criativa: desafios para a prática pedagógica. In: Claudio Pinto Nunes. (Org.). Didática e Formação de Professores. 1ed.Ijuí: Unijuí, 2012.

NETO, José Batista. A relação professor-aluno na perspectiva da diversidade: dimensão didático-metodológica. In: NETO, José Batisa. SANTIAGO, Eliane (Orgs). Recife: Fundação Joaquim Nabuco, Ed. Massangana, 2006.

NUNES, Leonília de Souza. Escuta sensível do professor: uma dimensão da qualidade da educação infantil. 2009. 110 f. Dissertação (Mestrado em Educação)-Universidade de Brasília, Brasília, 2009.

PETRUCCI, Giovanna Wanderley et al . Adaptação cultural e evidências de validade da Escala de Relacionamento Professor-Aluno. Aval. psicol., Itatiba, v. 13, n. 1, p. 133142, abr. 2014.

PRESTES, Zoia Ribeiro. Quando não é quase a mesma coisa: análise de traduções de Lev Semionovitch Vigotski no Brasil - repercussões no campo educacional. 2010. 295f. Tese (Doutorado em Educação) - Faculdade de Educação, Universidade de Brasília, Brasília, 2010.

ROCHA, Juliana Ferreira da; CARRARA, Kester. Formação ética para a cidadania: reorganizando contingências na interação professor-aluno. Psicol. Esc. Educ., Maringá, v. 15, n. 2, p. 221-230, Dec. 2011.

RODRIGUES, Silvia Souza de Miranda. A intersubjetividade na relação professor-aluno: questões para o trabalho pedagógico. 2014. 105 f. Dissertação (Mestrado em Educação) Universidade de Brasília, Brasília, 2014.

ROSEK, Marlene; SERRA, Rodrigo Giacobo. Dificuldades de aprendizagem e problemas emocionais: reflexões sobre a necessidade de uma proposta de formação docente. Educação por escrito, Porto Alegre, v. 6, n. 1, p. 167-184, jan.-jun. 2015. 
ROSSATO, Maristela. O movimento da subjetividade no processo de superação as dificuldades de aprendizagem escolar. 2009. 257 f., il. Dissertação (Mestrado em Educação)-Universidade de Brasília, Brasília, 2009.

ROSSATO, Maristela; MARINS, Luiz Roberto Rodrigues; MARTÍNEZ, Albertina Mitjáns. A construção do cenário social da pesquisa no contexto da Epistemologia Qualitativa. In.: MARTINEZ, Albertina M.; NEUBERN, Maurício; MORI, Valéria D. Subjetividade contemporânea: discussões epistemológicas e metodológicas. Campinas, SP: Editora Alínea, 2014.

SANTOS, David Almeida dos. Afeto e transferência na constituição do sujeito. 2015. 123 f. Dissertação (Mestrado em Educação)—Universidade de Brasília, Brasília, 2015.

SILVA, Alaídes Pereira da. Diálogo e qualidade na educação infantil: um estudo de relações na sala de aula. 2006. 98 f. Dissertação (Mestrado em Educação)-Universidade de Brasília, Brasília, 2006.

SOARES, Tufi Machado et al . A expectativa do professor e o desempenho dos alunos. Psic.: Teor. e Pesq., Brasília, v. 26, n. 1, p. 157-170, Mar. 2010.

TACCA, Maria Carmem V.R. Além de professor e de aluno: a alteridade nos processos de aprendizagem e de desenvolvimento. In: MITJÁNS MARTINEZ, Albertina; SIMÃO, Lívia Mathias (Org). O outro no desenvolvimento humano: diálogos para a pesquisa e prática profissional em psicologia. São Paulo: Pioneira Thomson Learning, 2004.

TACCA, Maria Carmen V. R. Estratégias Pedagógicas: conceituação e desdobramentos com o foco na relação professor-aluno. In: Aprendizagem e trabalho pedagógico. TACCA, Maria Carmen V. R. (Org), Campinas, SP: Editora Alínea, 2006a.

Relações sociais na escola e desenvolvimento da subjetividade. In: MALUF, Maria Irene (coord.). Aprendizagem: tramas do conhecimento, do saber e da subjetividade. Petrópolis, RJ: Vozes: São Paulo: ABPp -Associação Brasileira de Psicopedagogia, 2006b.

TACCA, Maria Carmen Villela Rosa; BRANCO, Angela Uchoa. Processos de significação na relação professor-alunos: uma perspectiva sociocultural construtivista. Estud. psicol.

(Natal), Natal, v. 13, n. 1, p. 39-48, abri. 2008.

TACCA, M. C. V. R. \& GONZÁLEZ REY, F. Produção de sentido subjetivo: as singularidades dos alunos no processo de aprender. Psicologia Ciência e Profissão, 28 (1), 138-161, 2008.

TUNES, Elizabeth, TACCA, Maria Carmem V. R. e BARTHOLO, Roberto dos Santos. O professor e o ato de ensinar. Cad. Pesqui., set./dez. 2005, vol.35, no.126, p.689-698. ISSN 0100-1574

TUNES, Elizabeth; BARTHOLO, Roberto. Da constituição da consciência a uma psicologia ética: alteridade e zona de desenvolvimento proximal. In: MITJÁNS MARTINEZ, Albertina; SIMÃO, Lívia Mathias (Org). O outro no desenvolvimento humano: diálogos para a pesquisa e prática profissional em psicologia. São Paulo: Pioneira Thomson Learning, 2004. 
VERAS, Renata da Silva; FERREIRA, Sandra Patrícia Ataíde. A afetividade na relação professor-aluno e suas implicações na aprendizagem, em contexto universitário. Educ. rev., Curitiba, n. 38, p. 219-235, dez. 2010 .

VIECILI, Juliane; MEDEIROS, José Gonçalves. A coerção e suas implicações na relação professor-aluno. Psico-USF (Impr.), Itatiba, v. 7, n. 2, p. 229-238, dez. 2002.

VIGOTSKI, Lev. S. História del desarrollo de las funciones psíquicas superiors. Obras escogidas. Tomo III. Mosocu: Ed. Pedagógica, 1931.

The problem of the environment. 1934. Disponível em.:

https://www.marxists.org/archive/vygotsky/works/1934/environment.htm

Aprendizagem e Desenvolvimento intelectual na idade escolar. Luria, Leontiev e Vigotski: bases psicológicas da aprendizagem e do desenvolvimento. São Paulo: Ed. Moraes, 1991.

A formação social da mente. $6^{\text {a }}$ ed. São Paulo : Martins Fontes, 1998.

Psicologia pedagógica. Porto Alegre: Artmed, 2001.

Pensamiento y habla. Buenos Aires: Colihue, 2012.

VIGOTSKI, Lev Semenovitch; LURIA, Alexander Romanovich; LEONTIEV, Alexei Nikolaevich. Linguagem, desenvolvimento e aprendizagem. São Paulo: Ícone, 2006. 


\section{APÊNDICES}

\section{APÊNDICE A - CARTA DE APRESENTAÇÃO}

Sra. Diretora e demais membros da equipe gestora,

Pertenço ao quadro de professores efetivos da Secretaria de Estado de Educação do Distrito Federal e, atualmente, estou cursando mestrado acadêmico em educação, no Programa de Pós-Graduação em Educação da Faculdade de Educação da Universidade de Brasília.

Minha pesquisa será realizada por mim, Luana Vaz, sob a orientação da Prof. ${ }^{a}$ Dr $^{a}$ Cristina Massot Madeira Coelho, e deve ocorrer por meio do acompanhamento de duas turmas do Bloco Inicial de Alfabetização. Para tanto solicito sua anuência para desenvolver minha pesquisa na Escola em que $\mathrm{VSr}^{\mathrm{a}}$ é gestora.

Aproveito para esclarecer aspectos do projeto de pesquisa:

Linha de pesquisa: Escola, Aprendizagem, Ação pedagógica e Subjetividade na Educação (EAPS).

Temática: A sala de aula como espaço relacional.

Problema de pesquisa: Como os professores buscam conhecer os alunos no contexto pedagógico e de que maneira organizam o trabalho pedagógico de acordo com a turma?

Objetivo geral do trabalho: compreender as dinâmicas relacionais da sala de aula e sua interface com a organização do trabalho pedagógico de professores de uma escola da rede pública de ensino do Distrito Federal.

Discussão teórica: Perspectiva histórico-cultural (Vigotski) e a Teoria da Subjetividade de González Rey.

Metodologia: Epistemologia Qualitativa de González Rey, a partir de estudo de casos. Acompanhamento do trabalho pedagógico realizado em turmas do Bloco Inicial de Alfabetização e acompanhamento dos momentos de planejamento do professor.

Instrumentos: Observação, entrevistas individuais, análise documental e outros necessários ao longo da pesquisa.

Desde já, agradeço a atenção e me coloco à disposição para outras informações que se façam necessárias. 


\section{APÊNDICE B - TERMO DE CONSENTIMENTO LIVRE E ESCLARECIDO}

Senhor(a) Professor (a),

Este é um convite para que participe da pesquisa "A sala de aula como espaço relacional: o olhar do professor para as singularidades dos alunos", realizada por Luana Vaz, sob orientação da Profa Dra Cristina Massot Madeira Coelho, que será apresentada à Universidade de Brasília como requisito parcial para obtenção do título de Mestre em Educação.

Durante a pesquisa serão propostos diferentes momentos de observação e conversação para que os participantes, de forma voluntária, partilhem informações relacionadas à sua prática pedagógica e história de vida profissional ou pessoal que sejam relevantes para a pesquisa. Ao longo desse estudo utilizaremos instrumentos escritos e registros de informações. Com sua autorização, as entrevistas poderão ser gravadas, exclusivamente para fins acadêmicos.

A assinatura desse Termo de Consentimento Livre e Esclarecido formaliza sua participação na pesquisa. Esclareço que você poderá deixar a pesquisa no momento em que desejar. Asseguro-lhe que serão mantidas em total sigilo a sua identificação, da escola e de qualquer outro participante. Os encontros que se fizerem necessário ocorrerão em dia, horário e local previamente acordado entre você e a pesquisadora. Desde já agradeço a participação.

Atenciosamente, Luana Vaz, aluna do PPGE/FE/UnB.

Declaro que li e entendi este termo de consentimento e que sou voluntário(a) a tomar parte neste estudo.

Assinatura da instituição participante

Assinatura da pesquisadora

Assinatura da orientadora

Brasília de de 2016. 


\section{APÊNDICE C - EIXOS DA ENTREVISTA COM A PROFESSORA}

- Dados de Identificação

- Formação acadêmica;

- Tempo de trabalho como professora;

- Tempo de trabalho nessa escola;

- Turmas com as que já atuou.

- Escolha/percurso profissional

- Como foi a sua escolha pela profissão?

- Fale um pouco sobre seu percurso profissional, momentos marcantes e desafiadores.

- Concepções/ organização do trabalho pedagógico/ ação docente

- Como você compreende o papel do professor na aprendizagem dos alunos?

- Quais são os principais focos no desenvolvimento do trabalho docente?

- Elementos relevantes no momento de planejar as aulas;

- Como foi feita a definição do modo de trabalhar com a turma?

- Por que alfabetizar a partir de histórias?

- Que estratégias que utiliza para conhecer e acompanhar os alunos?

- O que considera importante na relação com os alunos?

- Turma/alunos

- Fale um pouco sobre sua turma.

- Conte como foi o contato com a turma nos primeiros dias de aula;

- Como foram construídos os combinados?

- Qual o objetivo das atividades (dever de casa) para os pais/família? Como usam?

- Teve que realizar alguma adaptação no planejamento (qual e porquê)?

- Estamos chegando ao fim do $1^{\circ}$ bimestre. O que te apoia na construção dos relatórios dos alunos? Como você vê esse processo? 
- Dúvidas específicas percebidas nos momentos de observação e nas dinâmicas conversacionais.

- Você contou que tinha receio em relação ao aluno Evandro e que com o tempo mudou esse olhar. O que possibilitou essa mudança?

- Você disse que o Fernando deu muito trabalho na primeira semana de aula e que agora apresenta outro comportamento. O que mudou? A que você atribui essa mudança? 


\section{APÊNDICE D - COMPLEMENTO DE FRASES}

Prezada Professora,

Complete as frases abaixo com a primeira ideia que surgir em sua mente. Se necessário, utilize a folha em branco para dar continuidade às frases.

1- Eu gosto

2- O tempo mais feliz

3- Eu queria saber

4- Meu maior medo

5- Eu sou

6- Na escola

7- Sofro quando

8- Não posso

9- Eu preciso

10- Ser professor

11- Na vida as coisas

12- Fracassei

13- Odeio

14- Eu gostaria

15- Meu futuro

16- Minhas expectativas

17- Fico inconformado

18- Este lugar

19- Minha maior preocupação é

20- A sala de aula

21- Desejo

22- Eu, secretamente,

23- Espero

24- Fico triste

25- Queria poder mudar

26- Amo

27- Esforço-me

28- Eu prefiro 
29- Minha sala de aula

30- Frustra-me

31- Minha principal ambição

32- Eu sempre posso

33- Meu maior prazer

34- Tentarei conseguir

35- Minhas obrigações

36- Fico feliz

37- Eu brigo

38- Os outros

39- Me relaciono

40- Quando estou sozinha

41- Meus alunos

42- Não suporto

43- Não consigo

44- As crianças

45- Minha vida futura

46- Procuro

47- De vez em quando penso

48- Meu maior desejo

49- Meu tempo

50- Luto

51- O passado

52- Aborrece-me

53- Necessito

54- Ser professora

55- Minha infância

56- Fico deprimida quando

57- Algumas vezes

58- Em casa

59- Minha família

60- Quando posso

61- Minha maior frustração

62- Aprender 
63- Tenho dúvidas

64- Eu não quero

65- As pessoas

66- Preciso reorganizar

67- Quando eu era criança

Agradeço sua importante contribuição. 


\section{APÊNDICE E - REDAÇÃO \\ "EU E MINHA TURMA"}

Trata-se de um registro escrito livre, de gênero a ser escolhido por você, que represente um "retrato" da sua sala de aula. Imagine que você tenha que contar para um amigo que mora longe como é a sua turma e como têm sido os momentos que você e seus alunos têm vivenciado juntos. Você pode incluir ainda um posicionamento pessoal, reflexões, críticas, momentos marcantes, desafios...qualquer pensamento que considere relevante para compreender você e sua turma. 


\section{APÊNDICE F - DINÂMICA CONVERSACIONAL COM OS ALUNOS}

A partir da história "Uma professora muito maluquinha", de Ziraldo

\section{Questões norteadoras}

- O que vocês acharam da história?

- Qual parte gostaram mais? E qual parte gostaram menos?

- Quais as semelhanças e diferenças entre a turma da história e a turma de vocês?

- Falem sobre a turma de vocês.

- Falem sobre a professora de vocês. 